\title{
WestVirginiaUniversity
}

THE RESEARCH REPOSITORY @ WVU

Graduate Theses, Dissertations, and Problem Reports

2003

\section{Fungi associated with northern red oak (Quercus rubra ) acorns}

Dawn M. Washington

West Virginia University

Follow this and additional works at: https://researchrepository.wvu.edu/etd

\section{Recommended Citation}

Washington, Dawn M., "Fungi associated with northern red oak (Quercus rubra ) acorns" (2003). Graduate Theses, Dissertations, and Problem Reports. 1405.

https://researchrepository.wvu.edu/etd/1405

This Thesis is protected by copyright and/or related rights. It has been brought to you by the The Research Repository @ WVU with permission from the rights-holder(s). You are free to use this Thesis in any way that is permitted by the copyright and related rights legislation that applies to your use. For other uses you must obtain permission from the rights-holder(s) directly, unless additional rights are indicated by a Creative Commons license in the record and/ or on the work itself. This Thesis has been accepted for inclusion in WVU Graduate Theses, Dissertations, and Problem Reports collection by an authorized administrator of The Research Repository @ WVU. For more information, please contact researchrepository@mail.wvu.edu. 
FUNGI ASSOCIATED WITH NORTHERN RED OAK (Quercus rubra) ACORNS

By

\section{Dawn M. Washington}

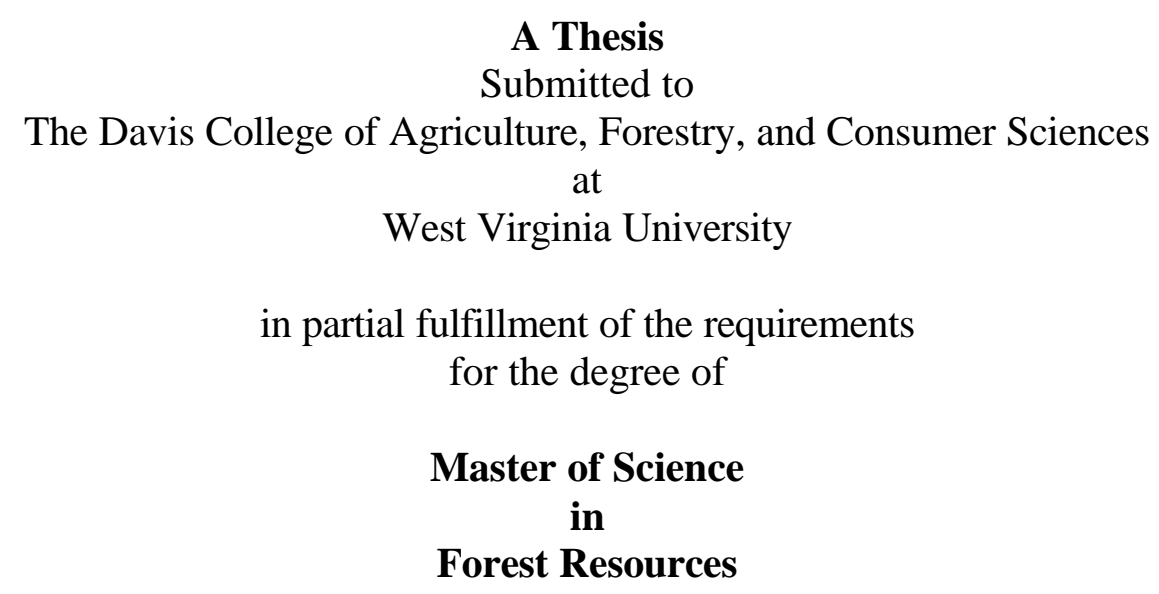

Division of Forestry

Ray Hicks Jr., Ph.D., Chair

Benjamin Dawson-Andoh, Ph.D.

William MacDonald, Ph.D.

Daniel Panaccione, Ph.D.

Morgantown, WV

2003

Keywords: Northern red oak, Quercus rubra, acorns, fungi, cotyledon discoloration, weevils, small mammals, burial, notching, and inoculation.

Copyright 2003 Dawn M. Washington 


\section{ABSTRACT \\ Fungi Associated with Northern Red Oak (Quercus rubra) Acorns}

\section{Dawn M. Washington}

Poor regeneration of northern red oak is widespread in the central hardwood region. A two-part study was conducted to determine what fungi are associated with and cause cotyledon discoloration of northern red oak acorns. The field study determined that simulated small mammal notching, surface sowing, time, and site all play a significant role in the amount of cotyledon discoloration in acorns as well as the number of acorns with discoloration. However, germination rate was only affected by site and surface sowing, while seedling vigor ratings were actually higher when acorns had discolored cotyledons. The five species of fungi isolated most frequently were Penicillium chermesinum, Penicillium terrestre, Rhizopus sp., Trichoderma sp. and Fusarium sp. These fungi were used to inoculate northern red oak acorns during two inoculation trials. Cotyledon discoloration occurred in all acorns, but highest levels were evident with the Penicillium terrestre inoculations. Germination rates were lowest in the second inoculation probably as a result of better sterilization techniques used. Therefore, fungi apparently do not have a significant negative impact on northern red oak regeneration unless they enter before germination. 


\section{DEDICATION}

I dedicate this, my first work, to my two beautiful children, Brekale and Savannah. You both kept me smiling no matter how crazy life can get. Secondly, to my loving and very supportive husband, Shannon, who has graciously put up with me and all the headaches along the way. Shannon, without you this thesis would have never been written. Thirdly, to my parents for pushing me to be my very best and especially my father for exposing me to the wonders of forests. Lastly to my loyal and hard working sister Stacey, who put up with all the constant obstacles throughout this research project and helped me through every last one of them all. 


\section{ACKNOWLEDGEMENTS}

The author wishes to express her sincere appreciation to Mr. Mark Double for his tireless efforts to assist me in anyway he possibly could; Dr. Ray Hicks Jr., Dr. Daniel Panaccione, Dr. William MacDonald, Dr. Benjamin Dawson-Andoh for assisting me as part of my appointed committee as well as the guidance and encouragement you have all given me throughout this entire project; Mr. George Siedel for his assistance in the statistical analysis; and Stacey Meyers for her constant help with every aspect of this research project. 


\section{TABLE OF CONTENTS}

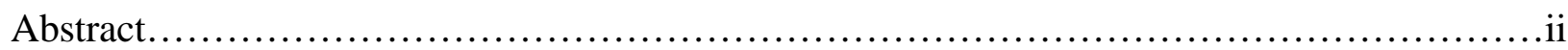

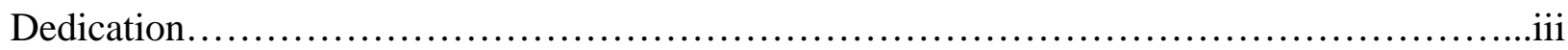

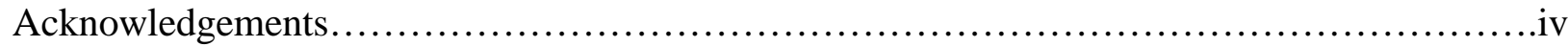

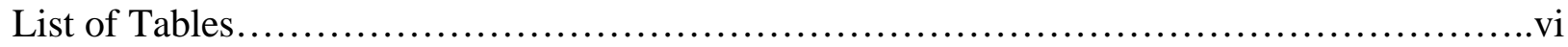

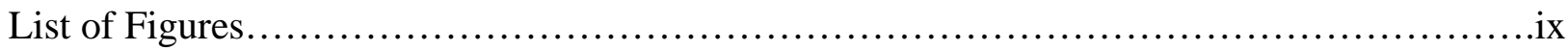

- Chapter 1:

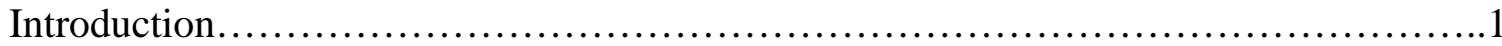

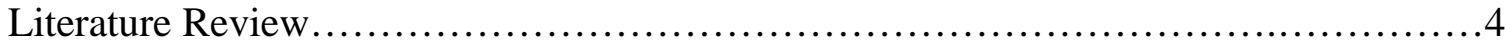

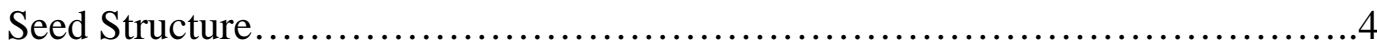

Seed Production...........................................................

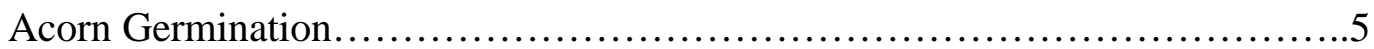

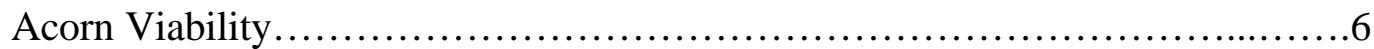

Fungi and Bacteria.................................................

Damage and burial of acorns by small mammals ....................... 8

Insects............................................................. 9

Interaction among factors.......................................... 10

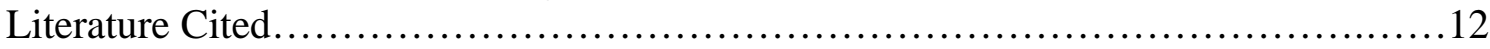

- Chapter 2: Fungi Isolated from Northern Red Oak Acorns after Simulated Small Mammal Notching and Burial

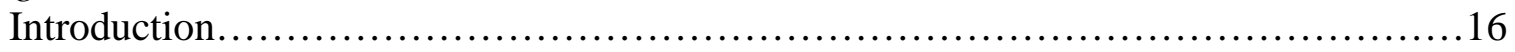

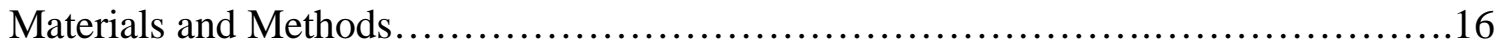

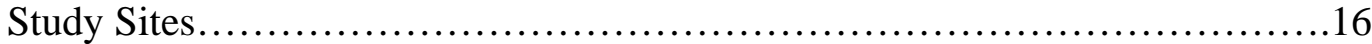

Field Methods............................................................... 18

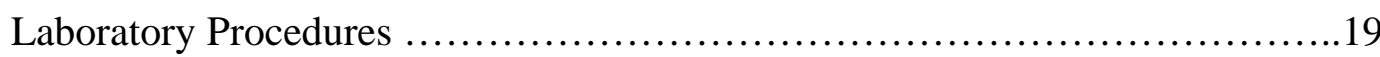

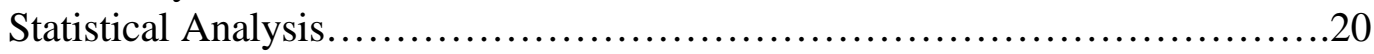

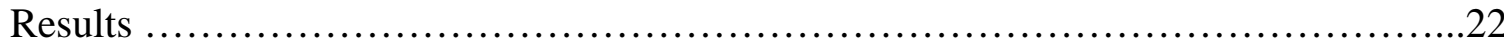

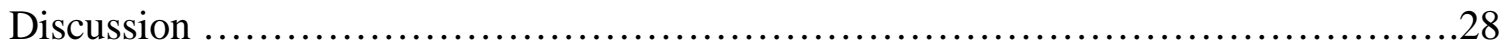

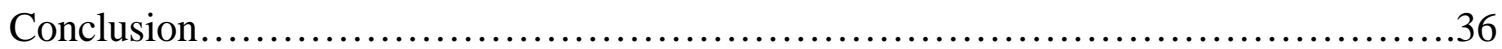

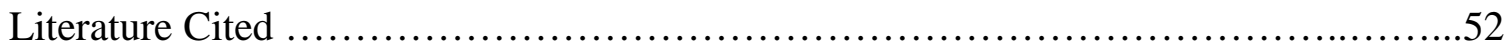

- Chapter 3: Inoculation and Germination of Northern Red Oak Acorns

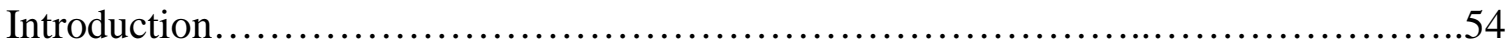

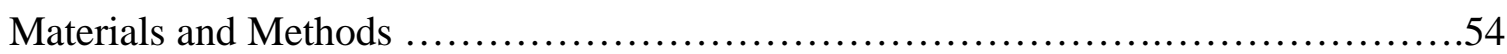

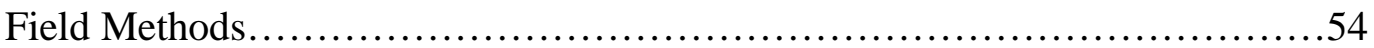

Laboratory Procedures.........................................................

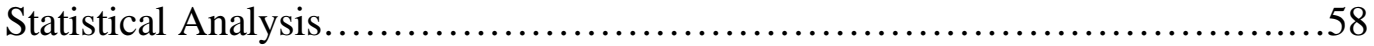

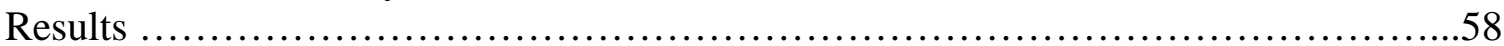

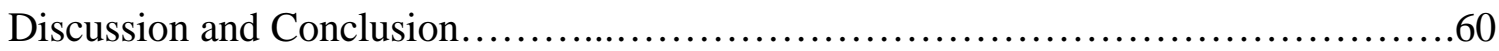

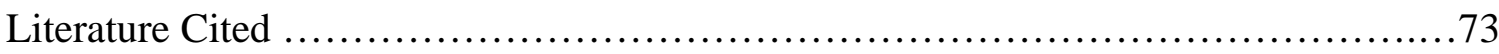

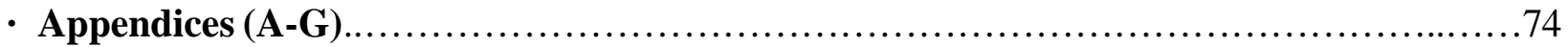




\section{CHAPTER 2}

\section{LIST OF TABLES}

Table 2.1. Description of seedling vigor rating system. .38

Table 2.2. Acorns with cotyledon discoloration and average percentage of cotyledon damaged by fungi....

Table 2.3. Acorns with concomitant cotyledon damage by fungi and weevils and average percentage of cotyledon damage attributed to fungi and weevils.

Table 2.4. Acorns damaged solely by weevils and average percentage of cotyledon damaged by weevils.

Table 2.5. Number of discolored, discolored/weevil damaged and weevil damaged acorns

associated with treatments by site.

Table 2.6. Number of acorns with discolored cotyledons by treatment, site and harvest date....42

Table 2.7. Germination rates for all three sites by treatment and harvest date.

Table 2.8. Germination rates for December-harvested acorn by site, treatment, and condition..43

Table 2.9. Germination rates for March-harvested acorn by site, treatment, and condition.....43

Table 2.10. Germination rate for March and June-harvested acorns with regard to amount of cotyledon discoloration

Table 2.11. Germination rates for June-harvested acorn by site, treatment, and condition.......44

Table 2.12. Average seedling rating for June harvested acorns by site and acorn condition......44

Table 2.13. Average seedling ratings for June-harvested acorns by site and treatment.

\section{CHAPTER 3}

Table 3.1. Visual assessment of the average amount of cotyledon discolored for first and second inoculation by time. .67

Table 3.2. Germination rates for first and second inoculations

Table 3.3. Frequency of fungi isolated from first inoculation. .68

Table 3.4. Frequency of fungi isolated from second inoculation .68 


\section{APPENDIX A}

Table A.1. Number of December-harvested acorns that have discolored, discolored/weevil

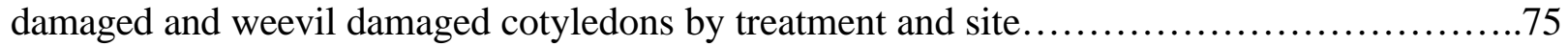
Table A.2. Number of March-harvested acorns that have discolored, discolored/weevil damaged and weevil damaged cotyledons by treatment and site.

Table A.3. Number of June-harvested acorns that have discolored, discolored/weevil damaged and weevil damaged cotyledons by treatment and site. .75

Table A.4. Number of acorns with discolored, discolored/weevil damaged and weevil damaged cotyledons by treatment, harvest date and site. ... .76

Table A.5. Number of acorns with discoloration and weevil damaged cotyledons by treatment,

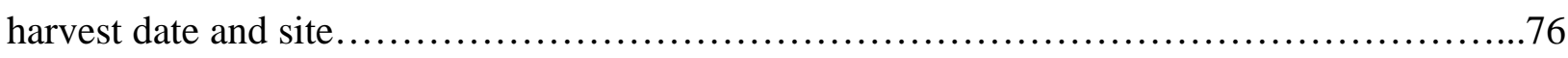

Table A.6. Number of weevil damaged acorns by treatment, harvest date and site.............76

\section{APPENDIX B}

Table B.1. Germination rates for all three sites by treatment and harvest date................78

Table B.2. Germination rates for sound acorns by site, treatment and harvest date.............78

Table B.3. Germination rates for acorns with discolored cotyledons by site, treatment and harvest date. .78

Table B.4. Germination rates for acorns with cotyledon discoloration and weevil damage by site,

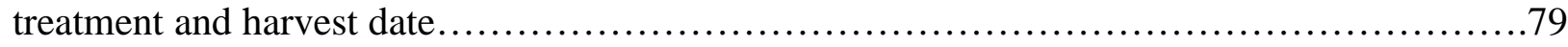

Table B.5. Germination rates for weevil damaged acorns by site, treatment and harvest date...79

Table B.6. Germination rates at Glade Run by harvest date and treatments...................79

Table B.7. Germination rates at Lick Run by harvest date and treatments...................80

Table B.8. Germination rates at Laurel Run by harvest date and treatments..................80

Table B.9. Germination rates of Glade Run sound acorns by harvest date, and treatment......80

Table B.10. Germination rates of Lick Run sound acorns by harvest date, and treatment......81

Table B.11. Germination rates of Laurel Run sound acorns by harvest date, and treatment......81

Table B.12. Germination rates of Glade Run acorns with cotyledon discoloration by harvest date

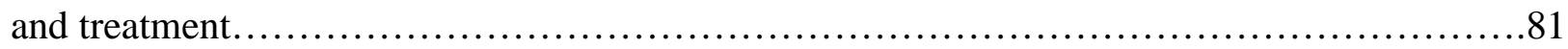

Table B.13. Germination rates of Lick Run acorns with cotyledon discoloration by harvest date and treatment. 
Table B.14. Germination rates of Laurel Run acorns with cotyledon discoloration by harvest

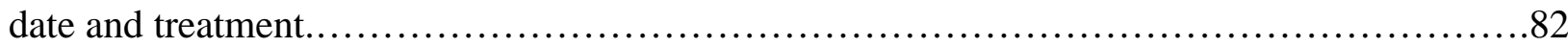

Table B.15. Germination rates of Glade Run acorns with cotyledon discoloration and weevil

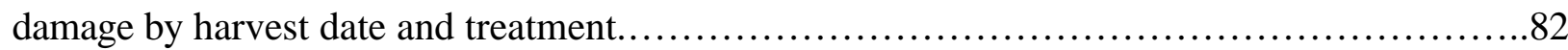

Table B.16. Germination rates of Lick Run acorns with cotyledon discoloration and weevil

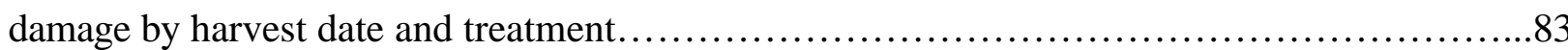

Table B.17. Germination rates of Laurel Run acorns with cotyledon discoloration and weevil

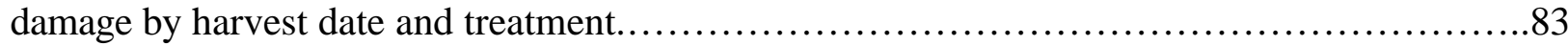

Table B.18. Germination rates of Glade Run weevil damaged acorns by harvest date and

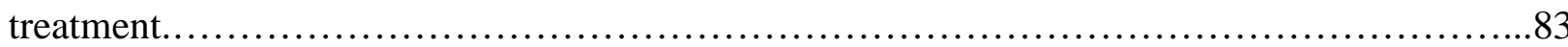

Table B.19. Germination rates of Lick Run weevil damaged acorns by harvest date and

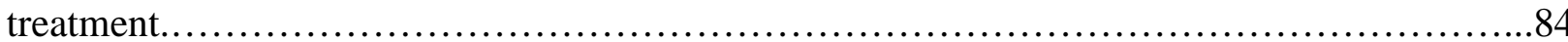

Table B.20. Germination rates of Laurel Run weevil damaged acorns by harvest date and

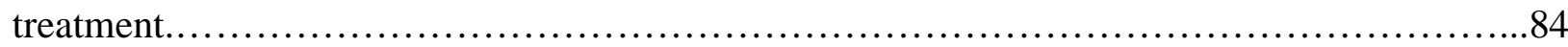

Table B.21. Overall germination rates by harvest date and treatment........................84

Table B.22. Germination rates for acorns at all three sites by harvest date....................85

\section{APPENDIX F}

Table F.1 Morphological Characteristics of Unidentified Fungi. 


\section{LIST OF FIGURES}

\section{CHAPTER 2}

Figure 2.1. Map of Glade and Lick Run study site locations............................45

Figure 2.2. Map of Laurel Run study site locations...................................46

Figure 2.3. Acorn placement in cages at each plot..................................47

Figure 2.4. Frequency of fungi isolated from acorns with discolored cotyledons..............48

Figure 2.5. Frequency of fungi isolated from acorns with discolored cotyledons and weevil

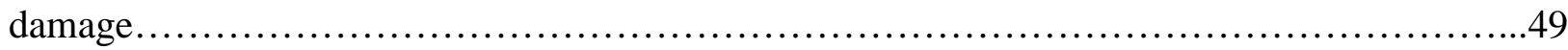

Figure 2.6. Frequency of fungi isolated from acorns with weevil damage...................50

Figure 2.7: Frequency of fungi associated with acorn shells at all sites......................51

\section{CHAPTER 3}

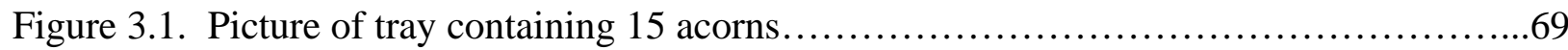

Figure 3.2: Average percent Cotyledon Discoloration Over Time for First Inoculation..........70

Figure 3.3: Average Percent Cotyledon Discoloration Over Time for Second Inoculation.......71

Figure 3.4: Frequency of Fungi Isolated from 50 Acorns that Sank During the Float Test......72

\section{APPENDIX C}

Figure C.1: Frequency of Fungi from Isolated from December-Harvested Acorns with

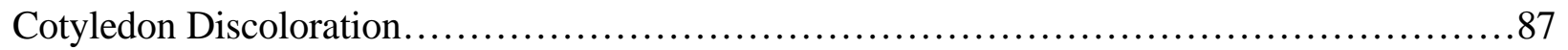

Figure C.2: Frequency of Fungi Isolated March-Harvested Acorns with Cotyledon

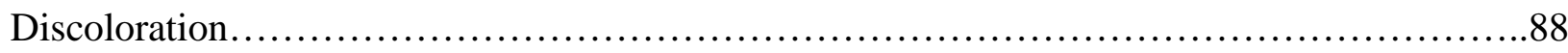

Figure C.3: Frequency of Fungi Isolated June-Harvested Acorns with Cotyledon

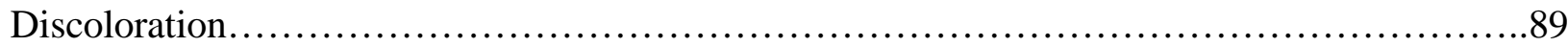

Figure C.4: Frequency of Fungi Isolated from Glade Run Acorns with Cotyledon

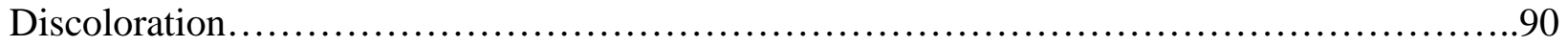

Figure C.5: Frequency of Fungi Isolated from Lick Run Acorns with Cotyledon

Discoloration.

Figure C.6: Frequency of Fungi Isolated from Laurel Run Acorns with Cotyledon

Discoloration. 
Figure C.7: Frequency of Fungi Isolated From Glade Run Acorns with Cotyledon Discoloration

Over Three Harvest Dates............................................................ 93

Figure C.8: Frequency of Fungi Isolated From Lick Run Acorns with Coytledon Discoloration

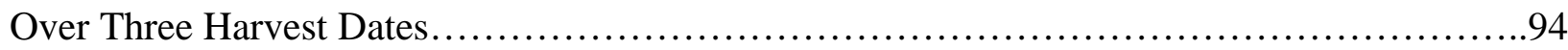

Figure C.9: Frequency of Fungi Isolated from Laurel Run Acorns with Cotyledon Discoloration

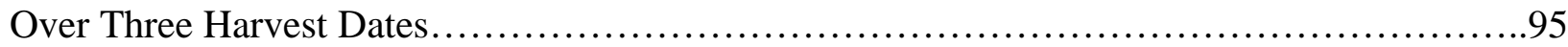

\section{APPENDIX D}

Figure D.1: Frequency Fungi Isolated from March-Harvested Acorns with Cotyledon

Discoloration and Weevil Damage.................................................... 97

Figure D.2: Frequency Fungi Isolated from June-Harvested Acorns with Cotyledon

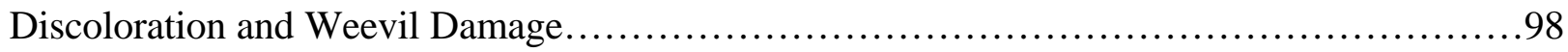

Figure D.3: Frequency of Fungi Isolated From June-Harvested Acorns with Cotyledon

Discoloration and Weevil Damage by Site......................................... 99

\section{APPENDIX E}

Figure E.1. Frequency of Fungi Isolated from December-Harvested Acorns with Weevil

Damage.

Figure E.2. Frequency of Fungi Isolated from March-Harvested Acorns with Weevil

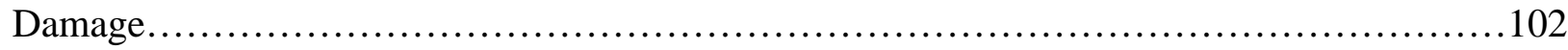

Figure E. 3. Frequency of Fungi Isolated from June-Harvested Acorns with Weevil Damage.103

Figure E.4. Frequency of Fungi Isolated From Glade Run Acorns with Weevil Damage......104

Figure E.5. Frequency of Fungi Isolated From Lick Run Acorns with Weevil Damage........105

Figure E.6. Frequency of Fungi Isolated From Laurel Run Acorns with Weevil Damage.......106

Figure E.7. Frequency of Fungi Isolated From Glade Run Acorns with Weevil Damage by

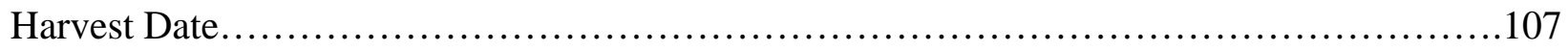

Figure E.8. Frequency of Fungi Isolated From Lick Run Acorns with Weevil Damage by

Harvest Date.

Figure E.9. Frequency of Fungi Isolated From Laurel Run Acorns with Weevil Damage by Harvest Date. 109 


\section{APPENDIX G}

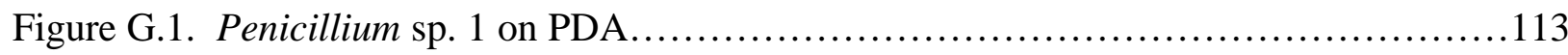

Figure G.2. Penicillium sp. 2 on PDA................................................ 113

Figure G.3. Penicillium sp. 1 and Penicillium sp. 2 (from left to right) on Czapeck Agar......114

Figure G.4. Trichoderma sp. 1 on PDA......................................... 114

Figure G.5. Fusarium sp. on PDA............................................... 115

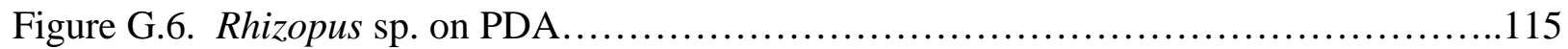

Figure G.7. Penicillium sp. 3 on PDA......................................... 116

Figure G.8. Unknown 2 on PDA............................................. 116

Figure G.9. Unknown 7 on PDA................................................ 117

Figure G.10. Unknown 18 on PDA........................................... 117

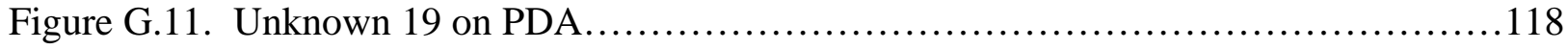

Figure G.12. Unknown 39 on PDA........................................... 118 


\section{Chapter 1}

\section{INTRODUCTION}

The genus Quercus is the most important group of hardwoods in the central hardwood region (Schopmeyer 1974 and Johnson et al. 2002). Oaks are found over a wide range of sites, from sandy to rocky, and from dry to moist; they occupy many different ecosystems. However, moist, well-drained coves and mid-to-low slope positions are optimal areas for oak growth (Schopmeyer 1974).

Generally, oaks begin fruiting at about 25 years of age, and bumper acorn crops are then produced erratically at 2-to-10 year intervals (Sander 1977). In the red oak group, acorns remain on the tree for two growing seasons. Ripening and dispersal occur in the fall between late August and early December (Schopmeyer 1974). Germination varies by species, but northern red oak (Quercus rubra) acorns require an over-wintering period before germination occurs the following spring.

Northern red oak is an important component of many forest ecosystems in the central hardwood region (Hicks 1998). Currently, the ability of this and other oak species to germinate, establish seedlings and mature into healthy trees is extremely low. This is especially true at the most productive sites. Site productivity in a forest is often measured in terms of site index, which is a relative measure of forest site quality based on the height growth rate of the dominant or codominant trees (Hicks 1998). The regeneration process includes production of adequate quantities of viable seed, seed germination, seedling establishment and release of seedlings into the canopy. Any factor that alters this chain of events can affect oak regeneration. Even when oak seedlings become established, they compete poorly with exploitive species like black cherry (Prunus serotina) and yellow-poplar (Liriodendron tulipifera) seedlings on good-to-excellent sites.

Aggressive species such as red maple (Acer rubrum), sugar maple (Acer saccharum), and American beech (Fagus grandifolia) are becoming the dominant canopy trees over much of the central hardwood region (Abrams 1998) and these less economically desirable species, from a 
forestry standpoint, are slowly replacing northern red oak (Hicks 1998). The reduction in importance of northern red and other oaks will have a dramatic effect on the entire forest ecosystem. Oaks are important timber species and northern red oak timber, in particular, is prized for veneer, furniture, and flooring. Acorns are an important winter food source for many wildlife species including white-tailed deer (Odocoileus virginianus), wild turkey (Meleagris gallopavo), black bear (Euarctos americanus), in addition to small mammals, and non-game birds. Thus, a reduction in northern red oak from the central hardwood region will have immeasurable ecological and economic effects.

There are several theories for the lack of successful oak regeneration. Predation of acorns by small mammals and white-tailed deer as well as over-browsing by deer is apparently part of the problem. Fire also is believed to favor oak regeneration over other competing species (Brose and Van Lear 2000, and Van Lear and Watt 1993) and the exclusion of fire may be a partial explanation for poor oak regeneration. But certainly poor acorn production and survival is a potential problem.

Many biotic and abiotic factors affect germination of northern red oak acorns and seedling establishment. Fungi may be an important factor that limits viable seed for the reproduction of northern red oak, but little work had been done to document the role of fungi in oak regeneration. There are a host of fungi found on the forest floor that are involved in the decay of leaf litter. Northern red oak acorns over-winter in wet leaf litter; this environment can provide ideal conditions that promote fungal growth. Fungi not only affect acorns, but the seedlings they produce as well.

Fungi also have been implicated in the failure of seedlings to develop into saplings (Swiecki, et al. 1991). Leaf blisters, powdery mildews, wilts, blights, and leaf rusts all occur on external portions of many different tree species. Causal fungi for these diseases include: Taphrina spp., Phyllactinia corylea, Ceratocystis fagacearum, Cryphonectria parasitica, and Cronartium quercuum f. sp. fusiforme, respectively. However, most of these appear insignificant to oaks. Additionally, many decay fungi are internal wood decayers that produce external fruiting bodies. Ganoderma applanatum, Oxyporus populinus, Phellinus everhartii, Phellinus igniarius, and 
Fomes fomentarius are the main decay fungi of hardwoods in this region. Again, these fungal diseases are of little consequence to young oak seedling and saplings.

Regardless of the type of pathogenicity, all fungi require means of dissemination to survive and subsequently initiate infection. Since fungi are not self-propelled (with few exceptions), they must depend on exterior forces for distribution — wind, water, activities of birds, animals and insects, and dissemination of host plants. While some fungal dissemination occurs via hyphae, the major means of dissemination is through spores, either sexual or asexual. Some sexual spores are forcibly discharged, allowing for long-distance spread. Sporulation is sensitive to environmental conditions such as moisture, light and temperature. Given the proper conditions, fungal spores flourish in certain environments. Forest leaf litter can provide ideal conditions for fungal growth. Acorns in this environment encounter countless micoorganisms and are thus subject to this insult.

Unfortunately, research on fungi associated with acorns, especially northern red oak, has been limited. Thus, the purpose of this research is to investigate fungi that are associated with northern red oak acorn germination and seedling establishment. In addition, an attempt will be made to determine if fungi, isolated from acorns, are pathogenic to northern red oak. Particular objectives of this study include: 1) identification of the most frequently isolated fungi that are associated with northern red oak acorns; 2) determine if acorn treatments (notched-buried, notched-surface, sound-buried, and sound-surface) have significant impacts on cotyledons with regard to discoloration; 3) assessment of storage site conditions and acorn age in conjunction with cotyledon discoloration and weevil damage; and, 4) examination of fungi associated with weevil damaged acorns. In addition, an inoculation test utilizing the most commonly isolated fungi was conducted to assess the role of the various fungi in the reduction of acorn germination and seedling establishment in northern red oak acorns. 


\section{LITERATURE REVIEW}

The long-term persistence of northern red oak in forest ecosystems depends on the successful completion of a chain of events starting with seed production and germination culminating with seedling growth and maturation. Low seedling establishment of northern red oak is one of the many factors that adversely affect the regeneration process. In many cases, small seedlings are present, but larger saplings are lacking (Gribko et al. 2002). In the Appalachian region, seedlings often become established in single cohorts during years of high acorn production (Gribko 1995, Gribko et al. 2002, and Schuler and Fajvan 1999). Release of these seedlings requires perfect timing. The factors that can affect initial acorn establishment include: 1) seed structure; 2) seed production; 3) seed germination; and, 4) impact of insects, microorganism, and vertebrates (Gribko et al. 2002).

\section{Seed Structure}

Northern red oak acorns are generally large in size. Their cap is flat, shallow, and covers less than one-fourth of the shell. The cap is comprised of a woody central axis that contains the vascular tissues, surrounded by these tissues are layers of suberized bracts. The cap is attached to the hilum-like structure at the top of the acorn (Winston 1956). Korstain (1927) stated that the pericarp or shell is made up of five distinct layers. Two layers form the outside of the pericarp. The outermost layer is highly cutinized while the second is comprised of thin-walled parenchyma cells. The next layer, heavily lignified, is thick, yellow, and consists of sclerechyma cells. The fourth layer comprises the majority of the shell and consists of thick-walled parenchyma cells and groups of stone cells. The inner surface layer is comprised primarily of epidermal cells. Fibers form from these cells and create the thick inner mat that is typical of the red oak group. The cavity of the acorn contains the cotyledons; two cotyledons surround the embryo. A thin, dark-brown membrane, the testa, surrounds the cotyledon.

\section{Seed production}

As previously stated, fruiting (acorn production) begins at about age 25 for oaks, and bumper crops are produced erratically at 2-to-10 year intervals (Sander 1977). Northern red oak acorns, as with other Erythrobalanus oaks, mature in 2 years. Once ripened, acorns fall to the ground between late August and early December (Schopmeyer 1974). Northern red oak acorns need an 
over wintering, stratification period before germination can occur. Stratification is usually complete allowing acorns to germinate in the spring of the following year.

Acorn crops are typically heavy every three to four years (Olson 1974). However, there are factors that predictably influence acorn production (Cecich 1992); the most important are weather-related. Early in the spring the flowering process is directly affected by weather. Sork and Bramble (1993) examined acorn crops of white, black and northern red oak and found the size of acorn crops was positively influenced by warm spring weather during the time in which the acorns were maturing. Larger acorns also resulted from warm spring weather. Sharp and Sprague (1967) also concluded that warm weather in late April followed by cool temperatures in May, resulted in larger white oak acorn crops. A negative correlation was found between acorn production and summer drought and late spring frost (Sork and Bramble 1993). Sharp and Chisman (1961) found that pollination is affected by extreme temperature changes, wind, late frost, prolonged rain, and relative humidity. All these factors can decrease the amount of flowers that become pollinated.

Acorn crop variations also can occur within locations as well as among species (Johnson et al. 2002). Tyron and Carvell (1962) found that tree-to-tree variations were significantly greater than year-to-year variations in white and northern red oaks. Periodicity in acorn production results from variation in factors that affect the timing and frequency of flowering and fruiting as well as environmental factors. Periodicity involves production at fixed time intervals. With regard to the red oak group, periodic acorn crops are extremely difficult to predict as compared to the white oak group (Tryon and Carvell 1962). This is due to asynchronous production of acorn crops by different trees and the influence of unpredictable weather conditions including extreme temperatures, humidity, and rain.

\section{Acorn Germination}

As previously stated, northern red oaks and other species in the red oak group (subgenus Erythrobalanus) require a period of dormancy prior to germination. This dormancy is broken by cool, moist conditions for a period of 30 to 45 days in northern red oaks (Schopmeyer 1974). In northern regions and at higher elevations of the Appalachians, dormancy lasts much longer due 
to cold winter conditions that extend into March. This type of dormancy is referred to as embryo dormancy (Johnson et al. 2002).

Cool nighttime temperatures (averaging $10^{\circ} \mathrm{C}$ ) and daytime temperatures (averaging $18^{\circ} \mathrm{C}$ ) are ideal conditions for germination. However, germination will not occur unless the temperatures are consistently above $4.5^{\circ} \mathrm{C}$. Excessively high temperatures, $>26.5^{\circ} \mathrm{C}$ at night and $35^{\circ} \mathrm{C}$ during the day, can damage the acorn and thus reduce germination (Korstian 1927). Early spring thaws followed by late freezes and/or cold temperatures also can decrease germination rates.

The number of viable acorns is highly variable (Johnson et al. 2002). Korstian (1927) discovered that northern red oak acorns that are undamaged germinate at a rate of 75 to 90 percent if their moisture content is between 50 and 60 percent. Acorns from the red oak group germinated best when concentrations of crude fat and carbohydrates were at their maximum and moisture content was 40 percent (Bonner and Vozzo 1987). Germination rates can decrease due to desiccation or when the moisture content remains at 15 to 25 percent for an extended period (Korstian 1927; Bonner and Vozzo 1987). In another study Bonner and Vozzo (1987) found that, acorns that had become desiccated regained viability after rehydration.

Leaf litter provides the cool, moist environment required for stratification and germination of acorns. Although conditions in the litter layer are beneficial to acorns, it creates conditions that are also ideal for microorganisms to thrive (Korstian 1927). Bonner and Vozzo (1987) believe that microorganisms may play a role in softening the pericarp and thus encourage germination. Therefore, the very fungi that are beneficial to the germination process may become detrimental when weather conditions (cool, moist) retard the development of the embryo.

\section{Acorn viability}

\section{Fungi and bacteria}

Fungi, bacteria, and other microorganisms associated with northern red oak acorns have received little attention. Winston (1956) published an account of microorganisms found in northern red oak acorns. He described in limited detail, several genera of organisms associated with acorns, at varying stages of decay. Only one species of Penicillium and one of Fusarium were found to 
initiate decay. Winston (1956) stated that these fungi were carried into the acorn by insects; while insects killed the embryo, decay fungi broke down the remainder of the acorn. He also noted that the style channel and the edges of the hilum provided another entry route for fungi.

Other fungi identified by Winston included an Oomycete (Pythium sp.), Zygomycetes (Mucor sp. and Rhizopus sp.), Entomophthorales (two species), Ascomycetes (Trichothecium roseum, Verticillium sp., Gliocladium penicilloides Corda, Phomopsis sp., Botrytis sp., and Chaetomium elatum), Basidiomycetes (Armillaria mellea, and Memmoniella echinata), and Deuteromycetes (Pestalozzia sp., Bermcularia sp., Alternaria sp., Penicillium sp. I, sp. II, Aspergillis sp., Fusarium sp. I, sp. II, Trichoderma lignorum Harz).

Dorsey et al. (1962) examined fungi as secondary invaders in acorns of black (Q. velutina), scarlet $(Q$. coccinea), and chestnut ( $Q$. prinus) oaks. The most commonly identified fungi were Phytophthora sp., Cytospora sp., Melanconium sp., Dothiorella sp. and Penicillium sp. They also noted that the genera Cytospora and Melanconium might be acorn parasites, but suggested that further investigations were necessary to verify this because primary fungal invaders were not explored.

Other researchers have identified specific organisms in acorns of several other oak species. The impact of diseases on acorns and naturally occurring seedlings of blue oak (Q. douglasii), in northern California was studied by Swiecki et al. (1991). Internal fungal growth was most frequently associated with acorns that had been damaged by other agents. Sporulating fungi were identified to genus when possible. Penicillium and Aspergillus were the genera most commonly identified colonizing acorns externally on the shell and/or internally on the cotyledon. In acorns with exit holes and internal boring from weevils, there was extensive sporulation by a species of Penicillium. Externally, fungi were often found to be associated with the abscission scar, where the cap connects to the acorn, but did not progress into the interior of the acorn. Other fungi observed in or on acorns included Fusarium oxysporum, Stemphylium sp., Trichothecium sp., and an unidentified Coelomycete (Swiecki et al. 1991). Sweicki et al. (1991) concluded that acorns fell prematurely from trees when they were damaged by fungi and/or insects. As the season progressed and acorns were harvested from the ground, damage ratings 
remained about the same. This was due to vertebrates consuming most of the sound as soon as they reached the ground. Although wounds caused by insects are the most common way for fungi to enter the acorn, the authors noted that fungi and bacteria do not require insects to facilitate entry.

The drippy nut disease pathogen (Erwinia quercina) has been documented from California live oak (Q. agrifolia) and interior live oak (Q. wislizenii) acorns (Hildebrand and Schroth 1967). In samples of English oak ( $Q$. robur) and sessile oak ( $Q$. petraea) acorns, the fungus that causes black rot has been identified (Ciboria batschiana) (Delatour and Morelet 1979). The presence of acorn fungi was the subject of a study involving white (Q. alba), cherrybark (Q. falcata var. pagodaefolia), water (Q. nigra), and willow oak (Q. phellos) by Vozzo (1984). Epicoccum purpurascens and Fusarium solani, were isolated from the acorn surface of white and water oak, but due to cracks in the shell they easily could have infected the cotyledon. There were unidentified fungi associated with white and water oak acorns as well (Vozzo 1984).

\section{Damage and burial of acorns by small mammals}

Acorns are an important food source for small mammals including squirrels (Sciurus spp. and Glaucomys spp.), chipmunks (Tamias spp.), and mice (Peromyscus spp.). They make up a significant percentage of a small mammal's winter diet (Van Dersal 1940, Korstian 1927). In two different studies, small mammals consumed more than half of the acorns placed out in late autumn (McShea and Schwede 1993, Gribko 1995). Because acorns have a high nutritive value small mammals seek them out for consumption, and in the process they inadvertently disperse them by caching, and scatterhoarding. This type of dispersal of acorns is not fully understood since the majority of acorns are not consumed immediately.

Many studies show an overwhelming relationship between acorn crops and small mammal populations from year-to-year (Bendell 1959, McCracken, et al. 1999, McShea 2000). Small mammals are also associated with the notching of acorns. Squirrels and other small mammals often notch or bite of the tips of acorns or part of the shell and then cache them. This notching sometimes destroys the viability of a substantial proportion of cached acorns (Wood 1938, Barnett 1977). Smith (1962) observed mice destroying more acorns than they actually consumed 
by notching and peeling. The few acorns that may remain viable have cotyledons that are exposed to external conditions such as fungal infection. This could lead to a greater risk of disease and insects entering, which could leave the embryo unviable (Smith 1962). However, there is a gap in the knowledge, about the effects of notching as an entry court for fungi.

White-footed mice (Peromyscus leucopus) and other Microtus species are more likely to consume acorns, rather than caching them for later use (Smith and Reichman 1984, Sork 1984). When mice cache acorns, they often do so in places where they have little chance of producing a seedling, such as under a log or rock (Sork 1984). A large proportion of acorns that are cached by mice are later consumed. Cached acorns, although not notched, are often damaged during handling by mice and a large portion is not viable (Smith 1962, Wood 1938, Barnett 1977).

The burial of acorns by small mammals poses other questions relating to acorn viability. Scatterhoarding is one technique that is commonly used by many acorn predators. Scatterhoarding is the dispersal and storage of one or a few food items at many scattered locations in the soil or litter within an animal's territory (Cahalane 1942). Because scatterhoarding usually involves shallow burial, this behavior could enhance the probability of acorn germination (Gribko and Washington 2001).

\section{Insects}

Many insects have been associated with the destruction of acorns (Winston 1956). However, there are only a few insects that damage the acorn during the germination period. These include: 1) acorn weevils (Curculio spp. and Conotrachelus spp.); 2) moths (filbertworm moth and acorn moth); 3) acorn gall wasps (cynipids); and, 4) nitidulid sap beetles (Johnson et al. 2002). Acorn weevils commonly account for most of the damage.

Curculio weevils are usually considered primary invaders (Johnson et al. 2002). The adult females chew a small hole in the shell of the acorn approximately two-to-three weeks before the acorns mature, and deposit an egg in the chamber that has been excavated near the inner surface of the shell. More than one egg may be placed in an acorn. Within 5-to-14 days, the larvae emerge and begin to feed on the acorn cotyledon. When the larvae exit the acorn, in the late 
autumn, they burrow into the soil. Weevils remain as larvae in the soil for 1-to-2 years then they pupate in the summer. The males and females mate and the female deposits her eggs in new acorns to repeat the cycle (Gibson 1969).

Infestation rates of Curculio weevils vary greatly. Studies have shown that single-year infestation rates range from 60 to 75\% (Dorsey 1967, Marquis et al. 1976, Gribko and Jones 1995), although infestations of less than 25\% have been reported (Brezner 1960, Galford et al. 1991, Steiner 1995). Dorsey et al. (1962) and Gibson (1982) recorded a 100\% infestation rate. Although the general belief is that Curculio-infested acorns are incapable of germinating, one study reported that a proportion of weevil infested acorns germinated (Gribko and Washington 2001).

Conotrachelus weevils are secondary invaders. The females lay their eggs in acorns that have been cracked or opened by other factors (Gibson 1972) including acorns that have been notched or partially consumed by wildlife (Johnson et al. 2002). After the larvae feed on the interior portion of the acorn and mature, they emerge by cutting an exit hole in the shell in the fall of the year. As with Curculio weevils, Conotrachelus larvae also burrow into the ground where they pupate and emerge in early summer to complete the cycle (Gibson 1972).

Because of their propensity to invade cracked acorns, Conotrachelus weevils infest white oak acorns more readily than red oak acorns in the autumn. This is because white oaks germinate immediately upon falling and the radical breeches the acorn shell, providing an entry point for the insects. As a consequence, Conotrachelus weevil populations are highest once acorns have fallen (Gibson 1964). However, their prominence in northern red oak acorns increases during years of poor white oak acorn production (Johnson et al. 2002). One study showed that northern red oak acorns were more likely to be infested by weevils in surface sown acorns than buried acorns (Gribko and Washington 2001).

\section{Interactions among factors}

There are many ways that fungi can enter acorns. These include the notching of acorns by small mammals and the penetration of the pericarp via insects. However, no study has documented whether fungi are introduced directly or indirectly by either of these agents. 


\section{Small mammals and fungi}

Mice, chipmunks, and squirrels can damage acorns by directly reducing viability. They may severely damage the cotyledon, which may result in the loss of viability. Winston (1956) observed squirrels smelling acorns and then discarding those that contained insects and/or were infected with microorganisms. Acorns selected were notched, thrown aside or taken up a tree. The opening created by small mammal notching provides an excellent entry court for fungi. A study completed in 2001 showed that burying acorns resulted in more disease than did placing them on the surface. No effort was made, however, to differentiate disease vectors in this study (Gribko and Washington 2001).

\section{Insects and fungi}

Insects also can introduce fungi into the acorn. Vozzo (1984) studied insect/fungi correlations in acorns. He isolated fungi from the head, gut, and carcass of Curculio larvae. A species of Penicillium was isolated from the head and carcass portions. However, Vozzo questioned whether insects are adequate vectors due to the small number of fungal spores that were isolated. Conversely, Winston (1956) isolated fungi from northern red oak acorns that were transported into the acorn via insects. He reasoned that insects were important vectors since larvae were found to have a large number of spores on their body and most discoloration of the cotyledon radiated out from the initiation point inside the acorn. Once insects killed the embryo, fungi began to decay the remainder of the acorn. In this way, Winston associated fungal entry with insects since they provided a method for fungi to enter the acorn and initiate the decay of the remainder of the cotyledon left by insects. 


\section{LITERATURE CITED}

Abrams, M.D. 1998. The red maple paradox. BioScience 48:355-364.

Barnett, R.J. 1977. The effects of burial by squirrels on germination and survival of oak and hickory nuts. American Midland Naturalist 98:319-330.

Bendell, J.F. 1959. Food as a control of a population of white-footed mice, Peromyscus leucopus noveboracensis (Fisher). Canadian Journal of Zoology 37:173-209.

Bonner, F.T. and J. A. Vozzo. 1987. Seed biology and technology of Quercus. UDSA Forest Service Southern Forest Experimental Station General Technical Report SO-66. 21 p.

Brezner, J. 1960. Biology, ecology, and taxonomy of insects infesting acorns. Missouri Agricultural Experimental Station Research Bulletin. 726. 40 pp.

Brose, P., and Van Lear, D.H. 2000. A shelterwood-burn technique for regenerating productive upland oak sites. Proceeding: Workshop on fire, people, and central hardwood landscape; March 12 - 14, Richmond, KY. Newtown Square, PA: USDA Forest Service Northestern Research Station General Technical Report NE-274. 123 p.

Calahane, B.H. 1942. Caching and recovery of food by the western fox squirrel. Journal of Wildlife Management 6:338-352.

Cecich, R.A. 1992. Flowering and oak regeneration. In Oak Regeneration: Serious Problems, Practical Recommendations. USDA Forest Service General Technical Report ES-84. 79-95.

Delatour, C. and M. Morelet. 1979. La pourriture noire des glands. Rev. Forestiere Francaise 31:101-115 [Seed Abstracts. 1980. 3:1737]

Dorsey, C.K. 1967. Experiments to control acorn weevils with systemic insecticides. Forest Science 31:101-115 [Seed Abstracts. 1980. 3:1737].

Dorsey, C.K., E. H. Tryon, and K. L. Carvell. 1962. Insect damage to acorns in West Virginia and control studies using granular systematic insectidies. Journal of Economic Entomology. 55: 885-888.

Galford, J.G. and D. Weiss-Cottrill. 1991. Response of insects to damaged and undamaged germinating acorns. USDA Forest Service Research Paper NE-656 7 p.

Gibson, L.P. 1964. Biology and life history of acorn-infesting weevils of the genus Conotrachelus (Coleoptera: Curculioidae). Annual Entomology Society of America 57:521-526.

Gibson, L.P. 1969. Monograph of the genus Curculio in the New World (Coleoptera: 
Curculioidae): Part I. United States and Canada. Miscellaneous Publication Entomology Society of America 6:241-285.

Gibson, L.P. 1972. Insects that damage white oak acorns. USDA Forest Service Research Paper NE-220 $7 \mathrm{p}$.

Gibson, L.P. 1982. Insects that damage northern red oak acorns. USDA Forest Service Research Paper NE-492 $6 \mathrm{p}$.

Gribko, L.S. 1995. Effects of small mammals and acorn insects on survival and germination of northern red oak acorns in north-central West Virginia. Morgantown, WV: West Virginia University, Division of Forestry. 195 p. Ph.D. dissertation.

Gribko, L.S. and W.E. Jones. 1995. Test of the float method of assessing northern red oak acorn viability. Tree Planter's Notes 46:143-147.

Gribko, L.S., T.M. Schuler, and W. M. Ford. 2002. Biotic and abiotic mechanisms in the establishment of northern red oak seedlings: a review. Gen. Tech. Rep. NE-295. Newtown Square, PA: USDA, Forest Service, Northeastern Research Station. 18 pp.

Gribko, L.S. and D. M. Washington. 2001. Viability of northern red oak acorns infested by Curculio weevil larvae. Unpublished Data.

Hicks, R.R., Jr. 1998. Ecology and Management of Central Hardwood Forests. John Wiley and Sons. New York. 412 pp.

Hildebrand, D.C. and M. N. Schroth. 1967. A new species of Erwinia causing drippy-nut disease of live oaks. Phytopathology 57:250-253.

Johnson, P.S., S. R. Shifley, and R. Rogers. 2002. Regeneration ecology I: flowering, fruiting and reproduction characteristics. In: The ecology and silviculture of oaks. CABI Publishing, New York, NY. 503 pp.

Korstian, C.F. 1927. Factors controlling germination and early survival in oaks. Bulletin No. 19. New Haven, CT: Yale University, School of Forestry. 115 p.

Marquis, D.A., P. L. Eckert, and B.A. Roach. 1976. Acorn weevils, rodents, and deer all contribute to oak regeneration difficulties in Pennsylvania. USDA Forest Service Research Paper NE-365. 5 pp.

McCracken, K.E., J.W. Witham, and M.L. Hunter, Jr. 1999. Relationships between seed fall of three tree species and Peromyscus leucopus and Clethrionomys gapperi during 10 years in an oak-pine forest. Journal of Mammology 80:1288-1296.

McShea, W.J. and G. Schwede. 1993. Variable acorn crops: responses of white-tailed deer and other mast consumers. Journal of Mammology 74:999-1006. 
McShea, W.J. 2000. The influence of acorn crops on annual variation in rodent and bird populations. Ecology 81:228-238.

Olson, D.F., Jr. 1974. Quercus L. Oak. USDA Forest Service Agriculture Handbook 450, 88 pp.

Sander, I.L. 1977. Manager's handbook for oaks in the north central States. USDA Forest Service General Technical Report NC-37, 35 p. North Central Forest Experimental Station, St. Paul, Minnesota.

Schopmeyer, C.S., tech. coord. 1974. Seeds of woody plants in the United States. USDA Forest Service Agricultural Handbook No. 450, 883 pp.

Schuler, T.M. and M.A. Fajvan. 1999. Understory tree characteristics and disturbance history of a central Appalachian forest prior to old-growth harvesting. Research Paper NE-710. Radnor, PA: USDA, Forest Service, NE Research Station. 12 p.

Sharp, W.M. and H.H. Chisman. 1961. Flowering and fruiting in the white oaks: I. Staminate flowering through pollen dispersal. Ecology 42:365-372.

Sharp, W.M. and V. G. Sprague. 1967. Flowering and fruiting in the white oaks: pistillate flowering, acorn development, weather, and yields. Ecology 48:243-251.

Smith, C.C. and O. J. Reichman. 1984. The evolution of food caching by birds and mammals. Annual Rev. Ecology Syst. 15:329-351.

Smith, R.L. 1962. Acorn consumption by white-footed mice. West Virginia University Agricultural Experimental Station Bulletin 482T. 15 pp.

Sork, V.L. 1984. Examination of seed dispersal and survival in red oak, Quercus rubra (Fagaceae), using metal-tagged acorns. Ecology 65:1020-1022.

Sork, V.L. and J. E. Bramble. 1993. Prediction of acorn crops in three species of North American oaks: Quercus alba, Q. rubra, and Q. velutina. Annales Des Sciences Forestierres 50 (Suppl. 1): 128s-136s.

Steiner, K.C. 1995. Autumn predation of northern red oak seed crops. pp. 489-494 in: Gottschalk, K.W., and Fosbroke, S.L.C. eds., Proc: Tenth Central Hardwoods Conference. March 5-8, 1995. Morgantown, WV. USDA Forest Service General Technical Report NE-197. 577 pp.

Swiecki, T.J., E. A. Bernhardt, and R. A. Arnold. 1991. Insect and disease impacts on blue oak acorns and seedlings. Proceeding on the symposium on oak woodlands and hardwood rangeland management; October 31 - November 2 1990, Davis, CA. USDA Forest Service General Technical Report PSW-126. pp. 149-155. 
Tyron, E.H. and K. L. Carvell. 1962. Acorn production and damage. West Virginia University Agricultural Experimental Station Bulletin 466T. 18 pp.

Van Dersal, W.R. 1940. Utilization of oaks by birds and mammals. Journal of Wildlife Management 4:404-428.

Van Lear, D.H. and J. M. Watt. 1993. The role of fire in oak regeneration. In: Proceedings: Oak Regeneration: Serious Problems, Practical Recommendations, D. Loftis and C. E. McGee (ed.). USDA Forest Service SEFES General Technical Report SE-84:66-78.

Vozzo, J.A. 1984. Insects and fungi associated with acorns of Quercus sp. USDA Forest Service General Technical Report S-40-43 p. Southern Forest Experimental. Station, Starkville, Mississippi.

Winston, P.W. 1956. The acorn microsphere, with special reference to arthropods. Ecology 37:120-132.

Wood, O.M. 1938. Seedling reproduction of oak in southern New Jersey. Ecology 19:276-293. 


\section{Chapter 2:}

\section{Fungi Isolated From Northern Red Oak Acorns after Simulated Small Mammal Notching and Burial}

\section{INTRODUCTION}

Many factors regulate the germination success of northern red oak acorns including small mammals, insects, microorganisms, and environmental conditions. While all of these may play a role, research is limited on the microbial agents that influence northern red oak acorn viability; although some studies have been conducted on microorganisms associated with acorns of other oak species. This research investigated fungi and weevils that may affect northern red oak acorn germination and seedling establishment. Bacteria and actinomycetes were not examined. In this study, I tested if an association existed between cotyledon discoloration, weevil presence and fungi presence during different acorn developmental stages. Four treatments (notched-buried, notched-surface sown, sound-buried and sound-surface sown) were examined at three sites during three harvest periods to evaluate the fungi and weevils that impact acorns after dispersal.

\section{MATERIALS AND METHODS}

\section{Study Sites}

This one-year study was initiated in October 2001. The three study sites were located on the West Virginia University Forest (WVUF) in Monongalia and Preston Counties, WV. The WVUF, located on the western-most anticline of the Allegheny Mountains, is in the Unglaciated Allegheny Plateau Physiographic Province. The mean elevation is $596 \mathrm{~m}$ with a range of 318 to $976 \mathrm{~m}$ (Fenneman 1938). The average maximum and minimum temperatures are $22.0^{\circ} \mathrm{C}$ and $7.1{ }^{\circ} \mathrm{C}$ in August and January, respectively. Average annual rainfall is $104 \mathrm{~cm}$ (NOAA 1999).

One site was located along Lick Run Road in the Lick Run watershed. A second was located in the Glade Run watershed, and the third in the Laurel Run watershed (Figures 2.1, 2.2). The three sites will be referred to as Lick Run, Glade Run and Laurel Run. Forests at these sites include a significant basal area of northern red oak that ranged from 70-80 years of age.

The Lick Run site was the most productive site of the three, indicated by a northern red oak site index of 89 ( $\mathrm{SE}=2.7)$. Lick Run had a gentle northeast-facing slope (0-7\%) and the site was 
located at midslope. The two most dominant overstory species at this site were yellow-poplar (Liriodendron tulipifera) and northern red oak (Quercus rubra). These two species accounted for $74 \%$ of the basal area in the stand. Other canopy species included black cherry (Prunus serotina), white oak (Quercus alba), cucumbertree (Magnolia acumminata), and chestnut oak (Quercus prinus) (Gribko and Washington 2001). Using the Society of American Foresters cover type designation, this stand was classified as type 59 (yellow-poplar-white oak-northern red oak) (Eyre 1980). The most dominant species in the understory was red maple (Acer rubrum). Other understory species included black gum (Nyssa silvatica), witch-hazel (Hamamelis virginiana), hickory (Carya spp.), and black birch (Betula lenta) (Gribko and Washington 2001).

Glade Run was a northwest-facing site with a slightly steeper inclination (12-17\%) than Lick Run. The site index for northern red oak at this site was 72 ( $\mathrm{SE}=1.3$ ), with northern red oak and black cherry accounting for $80 \%$ of the basal area in the overstory. Other canopy species included yellow-poplar, chestnut oak, black oak (Quercus velutina), and cucumbertree. The most dominant understory species again was red maple. Other understory species included black gum, witch-hazel, black birch, and mountain holly (Ilex montana) (Gribko and Washington 2001). The forest cover type for this site also was classified as a variant of the SAF type 59 (Eyre 1980).

The rocky, most exposed site with regard to sunlight was Laurel Run. This study area was located on a flat-topped ridge with a slight southeastern aspect. The slope ranged from 0 to $6 \%$. The site index for northern red oak at this site was 60 ( $\mathrm{SE}=1.0$ ), indicating that the Laurel Run site was the poorest of the three. Chestnut oak, scarlet oak (Quercus coccinea), and white oak accounted for $78 \%$ of the basal area. Associated canopy species were black oak, northern red oak, and red maple. The understory was comprised of red maple, black cherry, black gum, and sourwood (Oxydendrum arboreum) (Gribko and Washington 2001). The forest cover type was classified as a variation of the SAF chestnut oak type (type 44) (Eyre 1980). 


\section{Field Methods}

Research plots were established at each site under mature acorn-producing northern red oaks. Sixty caged plots were randomly established, twenty each at Glade Run, Laurel Run and Lick Run. Each plot consisted of a $0.3048-\mathrm{m}^{2}$ quadrat that was covered by a $1.27 \mathrm{~cm}$ wire mesh screen to create a cage or exclosure (Figure 2.3). The cage fully protected acorns from vertebrates, but permitted access by insects and microorganisms. A five centimeter depth of organic forest soil, obtained from each site at the time planting occurred, was added to the plots as the medium for acorn germination in each cage at all three sites.

Northern red oak acorns were collected near two of the sites in during the first two weeks of October 2001. Only acorns that appeared to be viable, with no visible external damage, e.g. weevil exit holes, were collected from approximately ten mature trees near Lick and Glade Run. No acorns were collected at Laurel Run due to poor acorn production. Acorns from the two sites were mixed thoroughly, soaked in water for 24 hours and float-tested in water to further determine their viability (Gribko and Jones 1995). The acorns that were planted in the test were those that sank during the float test and were free of external insect damage or discoloration. Acorns were stored in trays covered with moist newspaper for approximately 3 weeks and refrigerated slightly above $0{ }^{\circ} \mathrm{C}$, prior to sowing in cages.

Thirty-six acorns were sown into the soil at each plot during the first week of November 2001. Eighteen acorns were notched, exposing a small portion of the cotyledon, to simulate small mammal damage and placed on one side of the cage. The remaining eighteen were not notched and placed on the other side of the cage. Half of each notching treatment was buried $2.54 \mathrm{~cm}$ deep in the forest soil to simulate scatterhoarding by small mammals; the other half were placed on the soil surface (Figure 2.3). Surface-sown acorns were firmly pressed into the soil to prevent rolling. Leaf litter was placed on top of the soil inside the cages and cages were then securely wired shut.

Acorns were harvested three times from each site. During the second week of December (December 15-16, 2001), one third of each acorn treatment and sowing technique (notchedburied, notched-surface, sound-buried, and sound-surface) was removed from each plot. The second group was harvested during the first spring thaw (March 20-21, 2002) and the third on 
June 5-6 2002 after germination was complete and a seedling was produced. Acorns were transported to the laboratory after each collection in closed zipper storage bags, where they were then stored at $2{ }^{\circ} \mathrm{C}$ until they were cultured.

\section{Laboratory Procedures}

\section{Preliminary Test}

To determine what culturing technique would be used for this study, 40 acorns were cultured as a trial run. Twenty of these acorns were randomly selected from the group that sank during the float-test (those that had apparently healthy cotyledons) and the other twenty acorns were randomly selected from those that floated (those that had cotyledons that were only discolored and did not have weevil exit holes). Both cotyledons and shells were cultured from each acorn to determine what fungi if any were present.

\section{Acorn from Study Sites}

Following each harvest, acorns from the field experiment were taken from storage and the shell was removed. Prior to culturing, visual conditions were noted. These conditions included: 1) percent cotyledon with discoloration; 2) percent weevil damage; 3) presence or absence of germination; and, 4) a seedling vigor rating (for June harvested acorns). When vestigial cotyledons were dissected, an ocular estimate to the nearest ten-percent was used to assess the discoloration and/or weevil damage of the cotyledon. This assessment was made by removing the cotyledon completely from the shell and examining it on all sides. Cotyledons and shells were then cultured to determine presence or absence of fungi. Culturing was completed within two months after harvest. Potato Dextrose Agar (PDA), a common medium for growing fungi from plant material, was used for culturing. PDA is comprised of $20 \mathrm{~g}$ of dehydrated potato, 20 $\mathrm{g}$ of glucose and $15 \mathrm{~g}$ of agar dissolved in 1 liter of distilled water. This solution was then sterilized by autoclaving at $125^{\circ} \mathrm{C}$ for 25 minutes and was allowed to cool to $45^{\circ} \mathrm{C}$ in a water bath. The antibiotics tetracycline hydrochloride $(50 \mathrm{mg})$ and streptomycin sulfate $(10 \mathrm{mg})$ were added to limit bacterial growth and then approximately 25 milliliters of the PDA medium was poured into sterile petri dishes. 
All acorn shells and cotyledons were cultured regardless of outward appearance. If a portion of the cotyledon from acorns with weevil damage was still intact, it was cultured to determine the associated fungi. In acorns with both discoloration and weevil damage, the portion with discoloration was cultured. Three pieces of the cotyledon and the shell from each acorn were plated onto PDA. All cotyledon and shell pieces were sterilized in a $0.1 \%$ sodium hypochlorite solution for 5 minutes, removed and placed on PDA. Three cotyledon samples were incubated per Petri dish. Shells of each acorn were treated similarly. Petri dishes were incubated at room temperature $\left(23-25^{\circ} \mathrm{C}\right)$ under fluorescent light in a 13:11 hour photoperiod. After approximately one week, resulting fungi were transferred to PDA to obtain pure cultures (one colony per plate).

In many cases, more than one fungus was isolated from a single acorn. Identification of some fungi was conducted based on isolate morphology and spore characteristics (shape, size, color) (Barnett and Hunter 1972). Many genera (i.e. Trichoderma, Penicillium, Pestalotia) were identified easily based on culture morphology. Those fungi that were not identified were listed in a table based on morphological characteristics including: 1) growth pattern, 2) mycelium color, 3) conidia, and 4) conidiophores (Appendix F). Pictures of some these unidentified fungi on PDA were also taken (Appendix G). Pure cultures of these unidentified fungi were stored on agar slants and stored at $2{ }^{\circ} \mathrm{C}$ for future microscopic examination.

A subjective rating system (1-4) was used to assess seedling vigor of the June-harvested acorns based on size of the root and shoot (Table 2.1). Ratings $>1$ indicated that the acorn germinated. Vigor ratings $>2$ and above were considered successful and healthy seedlings. Acorns that failed to germinate were given a rating of 0 .

\section{Statistical analysis}

\section{Descriptive Statistics}

The number of acorns from each sample period (December, March and June) and site were categorized into the following condition classes based on the cotyledon: discoloration, a combination of discoloration and weevil damage, weevil damaged only and sound. These data were classified by the four acorn treatments. Within each acorn condition category, the average percent discoloration and/or weevil damage was calculated. This value was calculated by 
averaging the amount of discoloration and/or weevil damage seen in each cotyledon by site, time of harvest and treatments. For cotyledons having both discoloration and weevil damage, an ocular estimate was recorded for each within ten percent. For example, an acorn could have 30\% weevil damage and $40 \%$ discoloration. Conversely, for some cotyledons, only discoloration or weevil damage was recorded.

The percent germination and average seedling vigor rating for all June harvested acorns was calculated by treatments (notched-buried, notched-surface, sound-buried, and sound-surface), site (Glade, Lick and Laurel Run), and condition of cotyledon (undamaged, discolored, discolored and weevil damaged, and weevil damaged). If an acorn germinated, it was given a value of 1 ; if it did not germinate, it received a value of 0 . Seedling ratings were based on the rating system described above. Both germination and seedling ratings were averaged and values were presented by site, treatments, and condition. Germination rates were presented as percentages while seedling ratings were calculated to the nearest hundredth.

The frequencies of fungi isolated from acorns with discolored cotyledons, cotyledons with both discoloration and weevil damage, cotyledons with only weevil damage, and shells of acorns with these conditions were analyzed by month of harvest and site. After an acorn was cultured, the fungi that were present in the culture were recorded. If a fungus was present, it was given a value of 1 ; conversely, if the fungus was not present, a value of 0 was recorded. These values were averaged and analyzed by site, time of harvest, treatment and condition. These frequencies were presented as percentages.

\section{Discolored and Weevil Damaged Acorns}

Analysis of variance was conducted to examine the interaction between average percent discoloration and the four main treatment effects. These effects include notching treatment (sound or notched); sowing technique (buried or surface sown); site (Lick run, Glade Run, or Laurel Run); and, harvest date (mid-December, mid-March, and first week of June). A Chisquare test was used to determine if weevil damage was independent of a discolored cotyledon. Analysis of variance also was conducted to examine relationships between seedling rating and 
the four main treatment effects. The alpha-level for significance in all statistical analyses was 0.05 .

\section{RESULTS}

Although fungi and weevils affected acorns independently, both agents were associated with some acorns simultaneously. Of the 2,160 acorns examined from all three sites, 255 (12\%) exhibited only cotyledons discoloration associated with fungi, 50 were discolored and damaged by weevils (2\%) and 186 were damaged solely by weevils (9\%) (Tables 2.2-2.4).

\section{Visual Assessment of Cotyledons with Discoloration}

Forty-three percent of the acorns tested at Laurel Run had discolored cotyledons, followed by Lick Run (35\%) and Glade Run (22\%) (Table 2.2). Laurel Run not only had the largest number of acorns with discoloration, but the highest percentage of cotyledon discoloration as well. The average amount of discoloration seen with acorns at Laurel Run averaged 53\%, followed by Lick Run (52\%) and Glade Run (36\%) (Table 2.2). Therefore, site was a significant factor with regard to the number of acorns with discoloration and the amount cotyledon that was discolored $(\mathrm{p}<0.0001)$ (Table 2.2).

A greater number of acorns harvested in June (51\%) had discoloration associated with their cotyledons than did those harvested in March (32\%) and December (17\%) harvested acorns (Table 2.2). The amount of visual cotyledon discoloration was highest in June as well, 62\%, followed by March (45\%) and December (15\%) (Table 2.2). Thus, time of harvest also was a significant factor in relation to cotyledon discoloration $(\mathrm{p}<0.0001)$.

Notching treatment and sowing technique were both significant, in relation to the amount of acorns with cotyledon discoloration $(\mathrm{p}<0.0001$ and $\mathrm{p}=0.0054$ respectively). Notched acorns accounted for the majority of the acorns with discoloration (62\%) while $38 \%$ of non-notched acorns had discoloration (Table 2.2). With regard to sowing technique, $62 \%$ of surface sown acorns had cotyledons with discoloration while buried acorns accounted for only $38 \%$ (Table 2.2). 
There were two significant two-way interactions as well. The first was between site and notching treatment $(\mathrm{p}=0.0015)$. Fungi damaged more cotyledons when acorns were notched and planted at Laurel Run (Table 2.5). The second significant two-way interaction was between sowing technique and notching treatment $(\mathrm{p}=0.0153)$. Acorns that were notched and sown on the surface resulted in significantly more acorns with discoloration (Table 2.5). This treatment combination had two times more acorns displaying discolored cotyledons than each of the other three treatment combinations.

There were two significant three-way interactions. Time, site and sowing technique was one significant three-way interaction $(\mathrm{p}<0.0001)$ indicating that most acorns that had discoloration were June-harvested, surface sown acorns at Lick Run. Also, acorns at Laurel Run in June that were buried also were seen in approximately similar numbers (Table 2.6). The second three-way interaction that was significant was between time, sowing technique and notching treatment $(\mathrm{p}=0.0194)$. This significant interaction was characterized by the fact that most acorns with discolored cotyledons were found in June with the notched-surface treatment (Table 2.6).

\section{Visual Assessment of Cotyledons Discolored and Damaged by Weevils}

In few cases, weevil damage was evident in conjunction with discoloration. Chi-square analysis revealed that there was an association between discoloration and weevil damage of the cotyledon. Most of the concomitantly infected acorns were associated with June-harvested acorns at Laurel Run (42\%), followed by Lick Run (39\%) and Glade Run (35\%) (Table 2.3). Also, most discolored and weevil-damaged acorns were associated with the notched-surface treatment (Table 2.5).

\section{Visual Assessment of Cotyledons Damaged by Weevils}

Some acorns were damaged solely by weevils at all sites. The harvest period with the highest percentage of acorns damaged by weevils (69\%) was June, followed by December (18\%) and March (13\%) (Table 2.4). Laurel Run had the highest percentage of acorns with weevil damage (60\%) followed by Glade Run (28\%), and Lick Run (12\%) (Table 2.4). The average amount of cotyledon damaged by weevils was highest at Laurel Run in June (84\%) (Table 2.4). With 
regard to weevil damage and treatments, a large number of weevil-damaged acorns were associated with surface-sown acorns, 70\% (Table 2.5).

\section{Fungi Associated with Acorn Cotyledons when Cultured}

There were five species of fungi that were most frequently observed in association with discolored cotyledons when cultured. Of these, Penicillium sp. 2 was most frequently isolated (Figure 2.4). The other four fungi, ranked by frequency, were Trichoderma sp., Penicillium sp. 1, Rhizopus sp. 1, and Fusarium sp. Penicillium sp. 2 also was the most frequently isolated fungus when the acorns were discolored and damaged by weevils (Figure 2.5). Other species of fungi that were associated with these acorns were Penicillium sp. 1, Rhizopus sp. 1, and unknown 7. Some weevil-damaged acorns had cotyledons that were completely destroyed; this condition prohibited culturing fungi. Of the less damaged acorns that were cultured, Penicillium sp. 2 was most commonly isolated. Penicillium sp. 1, Trichoderma sp., and Fusarium sp. also were frequently isolated from weevil-damaged acorns (Figure 2.6).

\section{Fungi Cultured from Acorn Shells}

Many fungi were isolated from acorn shells, regardless of their internal cotyledon condition. However, the species of fungus that was most commonly isolated from acorn shells at all three sites was Trichoderma sp. (Figure 2.7); it was isolated from shells at every site, over $60 \%$ of the time. Six other species of fungi also were isolated quite frequently; Penicillium sp. 1, Penicillium sp. 2, Rhizopus sp. 1 and unknowns 7, 10, and 15 (Figure 2.7).

\section{Identification of Pencillium sp. 1 and 2}

Penicillium sp. 1 was tentatively identified as Penicillium chermesinum. Colonies of this fungus appear velvety; conidiophores borne primarily as short branches from loosely trailing vegetative hyphae; conidial areas are light gray-green to mineral gray shades on Czapek agar; colonies are broadly zonate, radiately wrinkled and buckled, surface tufted, granular. Penicilli strictly Monoverticillate and consistently small, typically borne on short lateral branches. Conidia are small, globose to elliptical, 2.0 to 3.0 micrometers in length. This species appears to be fairly abundant in nature and is considered a soil microorganism since most of the strains examined by 
others have been obtained from organic substrata subject to contact with the soil or dust contamination (Raper and Thom, 1949).

Penicillium sp. 2 was tentatively identified as Penicillium terrestre. The Penicillium terrestre series consists primarily of forms isolated with considerable frequency from soil. They are characterized by loose-textured to floccose or lanose colonies, which typically show the production of abundant ropes of aerial vegetative hyphae (Raper and Thom 1949). Penicillium sp. 2 had asymmetric monoverticillate condiophores with funiculose hyphae; conidiophores were slightly roughened; metulae and sterigmata smooth. Colonies on Czapek agar were constricted attaining a size a $5.0-7.0 \mathrm{~cm}$ in $7-9$ days at $25 \mathrm{C}$; colonies were azonate and yellow-brown. It produced a strong odor, like certain mushrooms; exudates were limited, if present. Conidia were globose, mostly 3.0-4.5 micrometers and smooth-walled (Raper and Thom 1949).

\section{Germination Rates}

December-harvested acorns germinated at the lowest rate, compared to March and Juneharvested acorns. Glade Run had the highest December germination rate (15\%) followed by Laurel Run (3\%) and Lick Run (2\%) (Table 2.7). In March, Lick Run had the highest overall germination rate (93\%) followed by Laurel Run (80\%) and Glade Run (73\%) (Table 2.7). Glade Run had the highest June germination rate, averaged among all treatments, $99 \%$. Ninety-three percent of the Lick Run acorns germinated followed by Laurel Run, 62\% (Table 2.7). Germination rate varied by harvest date, acorn condition (sound, cotyledon discoloration, discoloration and weevil damage, and only weevil damage), and site.

\section{December Acorns}

December-harvested acorns were not expected to germinate, however, in some instances germination did take place. This was especially true at Glade Run (Table 2.8) where sound acorns germinated at a rate of $13 \%$, acorns with discolored cotyledons (30\%) and acorns with weevil damage (44\%). The germination rates at Lick and Laurel Run were extremely low. However, weevil damaged at Lick Run germinated at a rate of $9 \%$, while sound acorns at Laurel Run germinated at a rate of $4 \%$ (Table 2.8). 


\section{March Acorns}

Acorns harvested in March were just beginning to germinate. Overall germination rates by site were similar with Lick Run having the best germination, 93\%, followed by Laurel Run (80\%), and Glade Run (73\%) (Table 2.9). Acorns with discolored cotyledons had the lowest germination rates at all sites. Glade Run acorns with discolored cotyledons had an overall germination rate of 71\%, followed by Lick Run (64\%), and Laurel Run (38\%) (Table 2.9). All

other acorns, sound, weevil damaged, and discolored and weevil damaged, had germination rates greater than $85 \%$, with the exception of acorns that were discolored and weevil damaged at Laurel Run (Table 2.9).

For March-harvested acorns, the degree of cotyledon discoloration appeared to be associated with germination rates. Using four categories of discoloration $(0-25 \%, 26-50 \%, 51-75 \%$, and 76-100\%), germination rates were found to be much higher when the amount of cotyledon discoloration was less than $50 \%$ (Table 2.10). An exception to this was seen with acorns at Lick Run in which the germination rates were low within all ranges of discoloration.

\section{June Acorns}

Undamaged acorns (those that did not exhibit any discoloration or weevil damage of the cotyledon) at Glade and Lick Run exhibited higher germination rates when compared to Laurel Run in June. Glade Run had the best germination rate, 99\% (Table 2.11). However, Lick Run was only slightly less with $97 \%$ while Laurel Run had the lowest rate, 77\% (Table 2.11).

Acorns with discolored cotyledons germinated best at Glade Run, 97\% followed by Lick Run (76\%) and Laurel Run (63\%) (Table 2.11). The best germination rates for discolored and weevil damaged acorns were associated with Glade Run, 100\% followed by Lick Run (88\%) and Laurel Run (47\%) (Table 2.11). Weevil damaged acorns, harvested in June had a 100\% germination rate at both Glade and Lick Run, while Laurel Run's germination rate was only 17\% (Table 2.11). The poorest June germination rates in every condition category (undamaged, discolored, discolored and weevil damaged and weevil damaged) were associated with Laurel Run (Table 2.11). 
When germination rates for June-harvested acorns at Glade Run were examined based on cotyledon discoloration, there was no decrease in germination rate with increasing cotyledon discoloration (Table 2.10). However, at Lick Run, germination rate decreased from 0-25\% discoloration to $51-75 \%$ discoloration category and then increased in the highest category of discoloration (Table 2.10). On the other hand, germination rates at Laurel Run were similar (about 55\%) within all categories of discoloration, with the exception being the 51-75\% category of discoloration, where the germination rate was $80 \%$ (Table 2.10).

\section{Seedling Ratings}

Seedling ratings were extremely variable when compared to acorn condition and site. Lick Run had the best seedling rating regardless of condition (1.34) followed by Glade Run (1.20) and Laurel Run (0.82) (Table 2.12). The best seedling ratings at both Glade and Laurel Run were seen with acorns that had discolored cotyledons, average seedling ratings of 1.66 and 1.25 , respectively. In contrast, Lick Run's best seedling rating was noted with undamaged acorns, an average seedling rating of 1.64. The poorest seedling ratings were seen with weevil damaged acorns at all sites (Table 2.12).

Only two of the four main effects, site $(\mathrm{p}<0.0001)$, and sowing technique $(\mathrm{p}<0.0001)$ were significant with regard to a relationship between percent cotyledon discoloration and seedling rating. The time effect was excluded from the analysis because no seedlings were produced by December and March-harvested acorns. The best average seedling rating was seen at Lick Run (1.57) followed by Glade (1.52) and Laurel Run (0.85) (Table 2.13). Sowing technique influenced seedling ratings as well. Buried acorns had the highest overall average seedling rating (1.56) when compared to surface sown acorns (1.06) (Table 2.13).

There were two significant two-way interactions, which were between site and notching treatment $(\mathrm{p}=0.0157)$, and site and sowing technique $(\mathrm{p}<0.0001)$. The first interaction was characterized by the fact that notched acorns at Laurel Run had very low average seedling rating (0.70) compared to the other sites and non-notched acorns (Table 2.13). There was a second significant interaction between site and sowing technique illustrating that acorns sown on the surface at Laurel Run had an extremely low average seedling rating (0.27) (Table 2.13). There 
also was one significant three-way interaction between site, notching treatment, and sowing technique ( $\mathrm{p}=0.0354)$ with relation to amount of cotyledon discoloration and seedling rating. This was because the lowest average seedling ratings were seen at Laurel Run with notchedsurface acorns (0.10) (Table 2.13).

\section{DISCUSSION}

Northern red oak is an important component of many forest ecosystems in the central hardwood region (Hicks 1998). Currently, the ability of this species to germinate, establish seedlings and mature into healthy trees is extremely low. In order for regeneration of oaks to be successful, a series of events must take place from flowering, fruiting, germination, seedling survival to canopy assertion. This study focused on the acorn germination process, and specifically on the role of fungi in this process and to a lesser extent weevil damage. As part of this, several potential vectors of fungi (weevils and notching) were examined as well as environmental conditions (sowing technique: surface or burial, and planting site). Acorns were removed from the field after different lengths of time and examined for cotyledon discoloration and/or weevil damage. Cotyledons and shells from all acorns were cultured to assess the presence of fungi.

During this study, all acorns were cultured regardless of their internal condition. The first finding of interest was that (based on excision of tested acorns) when the acorns were cut open most were sound and healthy (77\%) when harvested from any of the three study sites (Tables 2.2-2.4). Thus, at least in the fall of 2001, the acorns that were collected for testing, for the most part, appeared sound and probably were capable of producing a seedling. Therefore, most acorns that are initially sound remain healthy throughout their course of development and are visibly undamaged by microorganisms and/or insects.

Because the twenty acorns with healthy cotyledons that were cultured in a preliminary test had no in vitro fungal association, it was assumed that this would hold true for the acorns in this study. However, in time every acorn used in this study had multiple fungi associated with them, regardless of their condition. Even apparently sound acorns that were only in cages for a month, December-harvested acorns, had fungi associated with them when cultured. 
The major conclusion from these results was that the twenty acorns from the preliminary study had no fungal associations due to the fact that they had just fallen from the tree. Therefore, fungi may not have had sufficient time to invade these acorns. However, if the fungi were present in or on the surface of these twenty acorns, colonization might have been so small that the Clorox treatment may have eliminated the fungi. Therefore, all acorns with healthy cotyledons in this study had must have had fungal spores or hyphae associated with their shells and cotyledons even though the fungi did not cause discoloration of the cotyledon.

Since new fallen acorns did not yield fungi when cultured, it was concluded that fungi must gain entry after the acorns enter the leaf litter. While the majority of acorns examined throughout this study had no cotyledon discoloration, fungi were cultured from all acorns, from either the cotyledon or the shell. These fungi may be acting as saprophytes, growing without perceivable damage to the acorn and only time is required for their internal establishment. It is possible that fungal entry may have occurred through the hilum, the top of the acorn where the cap connects via the tree's vascular system. This area is the softest part of the shell and may permit fungal entry. Winston (1956) stated that fungi might enter through the style channels around the hilum, where the cap is connected. It is plausible that fungi and other microorganisms might gain entry into an acorn while it is encompassed in the microbial-rich environment provided by soil.

Although most acorns were not damaged, 23\% of all acorns tested had some type of damage associated with their cotyledons. The majority of acorns that were damaged in this study were those with cotyledon discoloration (12\%) (Table 2.2). Cotyledon discoloration was found at all sites, within all treatments and during all harvest periods. However, of the 2,160 acorns examined in this study, only 305 had perceivable cotyledon discoloration (Tables 2.2, 2.3). In the acorns with cotyledon discoloration, conditions must have changed allowing the fungi to become more aggressive saprophytes or just colonize the acorns. The fungi responsible for cotyledon discoloration could be considered parasitic; however acorn germination was not significantly altered. If saprophytic fungi enter the acorn and cause no visible damage, they may have a less aggressive nature than the fungi causing discoloration. A second, sounder assumption is that there is a time factor involved. This means that the more time a fungus resides inside an acorn, the more colonization that will ultimately occur. 
Data in Table 2.2 indicate that of the acorns with cotyledon discoloration, $62 \%$ of them were notched, compared to the remaining, which were sound (38\%). Likewise, acorns placed on the surface of the soil were more susceptible to cotyledon discoloration than buried acorns.

Conditions in the microclimate in the notched and surface treatments must be altered enough to permit saprophytic fungi better access to the acorn. Notched acorns have an obvious entry court for fungi, while surface acorns may be exposed to drier conditions, thus altering the acorn's susceptibility. In an earlier study at these same sites, buried acorns were more likely to have discolored cotyledons than those that were sown on the surface (Gribko and Washington 2001). However, fungi were not examined in this study. This difference could be related to seasonal variations in fungi or environmental conditions at the time of the studies. For example, moisture and temperature have a tremendous influence on fungal growth and sporulation. Any changes in these factors can change the amount and type of fungi at a given area and from year-to-year.

Data from Table 2.2 also indicate that while notched and surface-sown acorns have a greater number of affected acorns, the percentage of cotyledon damage is nearly identical in all four treatments. Nearly one-half of the cotyledons became discolored once fungi entered the acorn. Conversely, the other half of the cotyledon remained undamaged. This unadulterated portion of the acorn was apparently sufficient for germination to occur, as germination rates among the four treatments was very good at Glade Run (97\% overall) and Lick Run (93\%) (Table 2.11).

Conversely at Laurel Run, the driest of the three sites, only $62 \%$ of the acorns germinated. There is a causal relationship between site, acorn condition and subsequent germination rate. Laurel Run had the greatest number of discolored acorns (43\%) and had the poorest germination rate (62\%). Twenty-two percent of acorns at Glade Run and 35\% of the acorns at Lick Run were discolored, but their germination rates were above 90\%. Thus, acorns at Laurel Run may be predisposed due to site conditions that were not conducive to germination.

With regard to germination, differences among acorn treatments only seemed to be applicable to Laurel Run, the xeric site. In the two mesic sites, germination was high, regardless of treatment. At Laurel Run, 54\% of notched acorns germinated compared to $70 \%$ of sound acorns. Likewise, twice as many buried acorns germinated compared to surface sown acorns at Laurel Run (Table 2.11). If the best conditions for acorns overall was sound-buried acorns, Laurel Run acorns were 
at a disadvantage from the beginning, given their poor performance compared to the two mesic sites.

The dry condition of Laurel Run may be attributed to its aspect. Lick Run and Glade Run are both north-facing slopes, while Laurel Run has a southeastern aspect. This condition is reflected by the stand's species composition. While northern red oak was a dominant component of the two mesic sites, it was relegated to an associated canopy species at Laurel Run. The presence of scarlet oak as a common canopy tree at Laurel Run shows the poor nature of the site due to the habit of this species to occupy poor, rocky sites.

This predisposition to moisture is seen in acorns concomitantly affected by fungi and weevils as well as acorns damaged solely by weevils. Data from Table 2.3 indicate a significantly higher number of acorns affected by fungi and weevils at Laurel Run (62\%) than Glade Run (22\%) or Lick Run (16\%). Figures for weevil-damaged acorns were similar; 60\% of acorns at Laurel Run were weevil damaged while only $28 \%$ and $12 \%$, respectively, were affected at Glade Run and Lick Run. Thus, site plays a much more significant role in acorn health than any of the treatments conducted in this experiment.

This study had similar findings to Winston's study in that discoloration was associated with weevil-damaged cotyledons of northern red oak acorns (Winston 1956). Winston's findings not only encompassed fungi that were associated with acorns, but bacteria, insects and many other organisms. He strongly believed that most fungi entered the acorns via insects. Therefore, insects were primary invaders of acorns while fungi and bacteria were secondary invaders.

Contrary to Winston's findings, Sweicki et al. (1991) looked at acorns that fell prematurely from blue oak trees due to fungi and/or insect damage. They concluded that insects do not facilitate entry of fungi and bacteria into an acorn. However, they stated that wounds caused by insects are the entry court for most fungi on blue oak acorns, but insects themselves did not carry fungi into the acorn. In acorns with exit holes and internal weevil boring, there was extensive sporulation by a species of Penicillium (Sweicki et al. 1991). 
Another study indicated that insects might not be vectors due to the small amount of fungal spores isolated from the insects' bodies (Vozzo 1984). Vozzo's results may have differed from Winston's due to the small number of observations in Vozzo's study. However, Sweicki's study stated that exit holes created by insects could be an entry point for fungi. He never concluded that the insects actually carried the fungi inside.

Prior to acorn abscission, adult Curculio weevils deposit eggs inside acorns (Gibson 1969). Sometimes more than one egg is deposited. This is one possible entry court for fungi. They may enter directly on the eggs that are deposited or while the adult weevil is creating a small hole for the eggs. Another possible conclusion is that fungi enter via the hole that was created after the eggs are deposited. While some Curculio infested acorns are released prematurely due to large amounts of damage, others are not. Sometimes the damage that results from this weevil is minimal. Consequently, the weevil may exit the acorn without completely destroying the cotyledon. As previously stated Sweicki et al (1991) thought that this exit hole could serve as a point of entry for fungi.

The weevils that did the damage during this study were Conotrachelus, since they generally invade acorns following a break in the acorn shell (Gibson 1972). Since Curculio weevils often damage the cotyledon to the point that germination fails (Gibson 1964), the data suggest that the weevil damage in this study may be attributed to Conotrachelus weevils since the majority of weevil infested acorns germinated. However, most weevils had already exited the acorns before they were harvested and analyzed, thus the opportunity to identify them was lost.

Another justification that the weevils that damaged these acorns were Conotrachelus is the fact that all acorns were float-tested prior to placement in the cages. Many acorns that floated were infested and damaged by Curculio weevils. Thus, in all likelihood, the weevil infestation occurred post-placement. However, an acorn that was not yet damaged very extensively may have the passed the float test without detection. Also many studies have speculated that Curculio infested acorns are incapable of germinating. In a previous study done at these same three sites, acorn germination rates were greatly reduced by Curculio damage (Gribko and Washington 
2001). However, some of these acorns were placed at the sites knowing that they were infested with Curculio weevils.

Not only do acorns have more cotyledon damage due to both fungi and weevils at the xeric site, but also the seedlings were in poorer condition. Using a 0-4 scale to rate seedling vigor, Glade Run and Lick Run had seedling ratings of 1.20 and 1.34, respectively (Table 2.13). In comparison, Laurel Run had a seedling rating of 0.82 . Thus, data indicate that seedling development was not correlated to acorn health, except at the Laurel Run site. This study shows that an acorn with an undamaged cotyledon was not needed to produce a vigorous seedling (Table 2.12).

When vigor of seedlings was examined at Laurel Run, it appeared that weevil attack generally led to lower vigor seedlings. In addition, surface sown acorns, produced seedlings that were less vigorous than those produced by buried acorns (Table 2.12). There was little or no association of cotyledon discoloration with vigor of the seedlings produced. In fact, acorns with discolored cotyledons seemed to produce more vigorous seedlings than apparently sound acorns. This finding was unexpected, but it may indicate that fungi could serve a beneficial role in the germination process, perhaps by helping soften the acorn shell. Therefore, there may be a mutual relationship between fungi and the acorn. Once the fungi aid in germination and the root and shoot are produced, the cotyledon is no longer needed. The fungi can now easily enter the acorn and destroy the no-longer-needed cotyledon.

However, this study shows that if fungi enter before germination takes place germination is reduced. To determine if fungi were detrimental to an acorn with regard to germination, acorns from March and June that had discolored cotyledons were closely examined and compared. Germination rates for acorns harvested in March were generally high (Table 2.9). However, as the average amount of cotyledon discoloration increased, germination decreased (Table 2.10). The only exception was seen at Lick Run where the germination rate for the highest category of discoloration was higher than the previous to categories (Table 2.10). This shows that if cotyledon discoloration is great early, the impact becomes greater and the acorns are less likely to germinate. 
The cotyledon is used as a source of food in the early stages of development. Discoloration may lead to a weakened seedling or result in mortality. However, once the acorn has germinated, the developing seedling had leaves and roots and therefore begins to photosynthesize. The cotyledon is then expendable and thus vulnerable to fungal attack. It is not surprising that geminating seedlings have highly discolored cotyledons as evidence (Table 2.12).

Conversely, acorns with cotyledon discoloration germinated well in June, with the exception of those at Laurel Run (Table 2.11). Also, as the amount of cotyledon discoloration increased, the germination rate stayed approximately the same with the exception of those acorns at Laurel Run (Table 2.10). There were some variations seen in germination rate with regard to the amount of discoloration in June, but more than likely these variations had to do with site conditions at Laurel Run.

There was an association seen with weevil-damaged acorns and seedling rating. At all three sites, the lowest mean seedling rating from June harvested acorns was associated with weevil damaged acorns (Table 2.12). This was expected because some acorn cotyledons with weevil damage were completely consumed, leaving nothing for a small seedling to grown from before a root was established. The lack of germination of these weevil-damaged acorns reduces the overall average seedling rating for this category of acorns.

\section{Fungi Associated with All Acorns}

Fungi cultured from cotyledons did not seem to differ significantly with regard to site, harvest date, treatments and acorn condition. However, one species of fungus was much more prominent than all other fungi with regard to discolored cotyledons. Penicillium terrestre was the fungus found in highest frequency associated with all sites, treatments, harvest dates and conditions. Other fungi that were associated with acorns that had discolored cotyledons included one species of Trichoderma, Rhizopus, Fusarium and another species of Penicillium, tentatively identified as Penicillium chermesinum (Figures 2.4-2.6).

Fungi also were cultured from the acorn's shells, which was a limited part of the test. While Pencillium terrestre was most commonly isolated from acorn cotyledons, Trichoderma sp. was most frequently associated with acorn shells (Figure 2.7). This fungus was three times more 
likely to be isolated from an acorns shell than all other fungi. Trichoderma sp. also was found in association with acorn cotyledons, but not as frequently. Therefore this fungus may not be parasitic to the acorn. In fact it may aid in germination by softening the shell.

These data are in agreement with Winston's study, which reported that species of Penicillium and Fusarium were found to initiate decay in northern red oak acorns (Winston 1956). However, Winston did not record how often these fungi were isolated, but simply noted decay initiation by specific fungi. Some fungi isolated frequently in our study also were mentioned in Winston's extensive list of fungi. These fungi included a species of Rhizopus, Trichoderma, and another species of Penicillium. With the exception of Penicillium sp. and Fusarium sp., most fungi isolated during our study were not reported in studies of other oak species. Therefore, the only fungus found in both studies was Penicillium.

Dorsey et al. (1962) looked at fungi as a secondary invader in association with black, scarlet, and chestnut oak acorns. The most commonly found fungi in the Dorsey et al. study were Phytophthora sp., Cytospora sp., Melanconium sp., Dothiorella sp. and Penicillium sp. They also noted that the genera Cytospora and Melanconium might be acorn parasites. In samples of English oak and sessile oak acorns, the black rot fungus (Ciboria batschiana) was identified (Delatour and Morelet 1979).

The impact of diseases on acorns and naturally occurring seedlings of blue oak in northern California was studied (Swiecki et al. 1991). Internal fungal growth was most frequently associated with cotyledons with large amounts of discoloration. Penicillium and Aspergillus were the genera that most commonly colonized acorns externally and/or internally. Externally, fungi seen often were limited to the abscission scar, where the cap connects to the acorn. This fungal colonization did not progress into the interior of the acorn. Other fungi observed in or on acorns from this study included Fusarium oxysporum, Stemphylium sp., Trichothecium sp., and an unidentified Coelomycete. Swiecki's study had similar fungi common to our study.

In a study involving four species of oaks (white, cherrybark, water, and willow), presence of fungi internally and externally was studied. Epicoccum purpurascens and Fusarium solani were 
isolated from both white and water oak acorns. These fungi were isolated from the acorn surface, but due to cracks in the shell they could have easily worked their way into the cotyledon. There were other fungi that were found in association with white and water oak acorns that could not be identified as well (Vozzo 1984).

Some fungi isolated in this study were identified easily, based on morphological characters. Other fungi in this study were not identified and were simply listed as 'unknowns'. Some of the unknown fungi could have been similar to studies conducted by Winston, Swiecki, and Vozzo. However, many of the previous studies dealt with other oak species in areas of the United States that have environmental and habitat conditions that differ from West Virginia. Thus, it is not surprising that this study isolated similar and varying fungi, compared to previous studies.

\section{CONCLUSION}

In conclusion, fungi seem to be associated with northern red oak acorns at many stages of development. Cotyledon discoloration in northern red oak acorns does not have a major impact on germination and seedling establishment. However, the effect on germination was significant if discoloration occurred at high levels before the acorn germinates. This study has shown that fungi may actually be beneficial in that seedling vigor ratings were higher when cotyledon discoloration was present.

As reported in other studies, weevils can be detrimental to acorns to the point where infestation prevents germination. However, this was only true at one site, Laurel Run. Most weevil damaged acorns at both Lick and Glade Run sites germinated at a high rate. Therefore, weevils appear to be much more detrimental to germination and seedling vigor on certain sites.

Site was an extremely important factor with regard to many findings of this study. The poorest site in relation to northern red oak site index, Laurel Run, had the highest numbers of acorns in each of the three categories of damage (cotyledon discoloration, discoloration and weevil damage, and weevil damage alone). Laurel Run also had the lowest germination and seedling ratings. 
Sowing treatment and time of harvest had a specifically significant effect on cotyledon discoloration and germination as well. Surface sowing had a high overall percentage of cotyledon discoloration that resulted in lower germination rates in March. June germination rates were not significantly affected by the amount of discoloration present. When surface sown acorns were compared to those that were buried, they had lower seedling vigor ratings as well. Notching, to simulate small mammal damage, was only significant with regard to the amount of cotyledon discoloration that was present. Therefore, small mammals are both beneficial and detrimental with regard to acorn germination in that they aid in germination by scatterhoarding acorns, but the often increase chances of fungi entering acorns by notching them.

This study has answered many questions about northern red oak germination and seedling establishment with regard to fungi and has raised other questions. Future studies may focus on when infection of acorns by fungi may actually occur. Do fungi enter when the acorn is produced, as it develops on the tree or once the acorn falls to the ground? Whatever the cause, the number of acorns that were damaged as a whole was low. Most acorns, even those infected with fungi, were sound and capable of germination. This may indicate that factors other than germination limit the establishment of northern red oak. 
Table 2.1. Description of seedling vigor rating system.

\begin{tabular}{|c|c|}
\hline Rating & Description \\
\hline 0 & Did not germinate. \\
\hline 1 & $\begin{array}{l}\text { Germinated but had weak root system or shoot dieback. Root and / or } \\
\text { shoot may have died back and not resprouted. Poor chance of survival. }\end{array}$ \\
\hline 2 & $\begin{array}{l}\text { Strong root system and / or strong shoot. Root or shoot may have died } \\
\text { back once and resprouted. Good chance of survival. }\end{array}$ \\
\hline 3 & Strong root system, strong healthy shoot, but no true leaves. \\
\hline 4 & Same as rating 3 but at least one set of true leaves present. \\
\hline
\end{tabular}


Table 2.2. Acorns with cotyledon discoloration and average percentage of cotyledon damaged by fungi.

\begin{tabular}{|c|c|c|c|}
\hline & $\begin{array}{l}\text { Total \# of } \\
\text { Acorns } \\
\text { Examined }\end{array}$ & $\begin{array}{c}\text { \# of Acorns with } \\
\text { Discolored } \\
\text { Cotyledons }\end{array}$ & $\begin{array}{l}\text { Visual Assessment of } \\
\text { Cotyledon Damage }\end{array}$ \\
\hline Overall & 2160 & $255(12 \%)$ & $49 \%$ \\
\hline \multicolumn{4}{|l|}{ Site } \\
\hline Glade Run & 255 & $56(22 \%)^{a}$ & $36 \%{ }^{a}$ \\
\hline December & 56 & $10(18 \%)$ & $16 \%$ \\
\hline March & 56 & $14(25 \%)$ & $25 \%$ \\
\hline June & 56 & $32(57 \%)$ & $48 \%$ \\
\hline Lick Run & 255 & $89(35 \%)^{\mathbf{a}, \mathbf{b}}$ & $52 \%$ \\
\hline December & 89 & $13(15 \%)$ & $12 \%$ \\
\hline March & 89 & $25(28 \%)$ & $50 \%$ \\
\hline June & 89 & $51(57 \%)$ & $63 \%$ \\
\hline Laurel Run & 255 & $110(43 \%)^{\mathbf{b}}$ & $53 \%^{b}$ \\
\hline December & 110 & $20(18 \%)$ & $16 \%$ \\
\hline March & 110 & $42(38 \%)$ & $49 \%$ \\
\hline June & 110 & $48(44 \%)$ & $71 \%$ \\
\hline \multicolumn{4}{|l|}{ Time } \\
\hline December & 255 & $43(17 \%)^{\mathbf{a}}$ & $15 \%^{\mathrm{a}}$ \\
\hline March & 255 & $81(32 \%)^{\mathbf{a}, \mathbf{b}}$ & $45 \%^{b}$ \\
\hline June & 255 & $131(51 \%)^{b}$ & $62 \%^{c}$ \\
\hline \multicolumn{4}{|l|}{ Treatment } \\
\hline Notched & 255 & $157(62 \%)^{a}$ & $46 \%^{a}$ \\
\hline Sound & 255 & $98(38 \%)^{b}$ & $53 \%^{a}$ \\
\hline \multicolumn{4}{|c|}{ Sowing Technique } \\
\hline Buried & 255 & $96(38 \%)^{\mathbf{a}}$ & $48 \%^{\mathrm{a}}$ \\
\hline Surface & 255 & $159(62 \%)^{b}$ & $49 \%^{a}$ \\
\hline
\end{tabular}

* Numbers in the same column (broken into the four main treatment effects) followed a different letter are significantly different at $\mathrm{P}=0.05$. 
Table 2.3. Acorns with concomitant cotyledon damage by fungi and weevils and average percentage of cotyledon damage attributed to fungi and weevils.

\begin{tabular}{|c|c|c|c|c|}
\hline & \multirow[b]{2}{*}{$\begin{array}{c}\text { Total \# of } \\
\text { Acorns } \\
\text { Examined } \\
\end{array}$} & \multirow[b]{2}{*}{$\begin{array}{l}\text { \# of Acorns with } \\
\text { Concomitant Damage } \\
\text { by Fungi and Weevils }\end{array}$} & \multicolumn{2}{|c|}{$\begin{array}{l}\text { Visual Assessment of } \\
\text { Damage Attributed to: }\end{array}$} \\
\hline & & & Fungi & Weevils \\
\hline Overall & 2160 & $50(2 \%)$ & $42 \%$ & $24 \%$ \\
\hline \multicolumn{5}{|l|}{ Site } \\
\hline Glade Run & 50 & $11(22 \%)$ & $35 \%$ & $21 \%$ \\
\hline \begin{tabular}{|l|} 
December \\
\end{tabular} & 11 & $0(0 \%)$ & $0 \%$ & $0 \%$ \\
\hline March & 11 & $1(10 \%)$ & $50 \%$ & $30 \%$ \\
\hline June & 11 & $10(90 \%)$ & $33 \%$ & $20 \%$ \\
\hline Lick Run & 50 & $8(16 \%)$ & $39 \%$ & $41 \%$ \\
\hline \begin{tabular}{|l|} 
December \\
\end{tabular} & 8 & $0(0 \%)$ & $0 \%$ & $0 \%$ \\
\hline March & 8 & $0(0 \%)$ & $0 \%$ & $0 \%$ \\
\hline June & 8 & $8(100 \%)$ & $39 \%$ & $41 \%$ \\
\hline Laurel Run & 50 & $31(62 \%)$ & $46 \%$ & $43 \%$ \\
\hline December & 31 & $0(0 \%)$ & $0 \%$ & $0 \%$ \\
\hline March & 31 & $1(3 \%)$ & $40 \%$ & $30 \%$ \\
\hline June & 31 & $30(97 \%)$ & $46 \%$ & $44 \%$ \\
\hline \multicolumn{5}{|l|}{ Time } \\
\hline December & 50 & $0(0 \%)$ & $0 \%$ & $0 \%$ \\
\hline March & 50 & $2(4 \%)$ & $45 \%$ & $30 \%$ \\
\hline June & 50 & $48(96 \%)$ & $42 \%$ & $38 \%$ \\
\hline \multicolumn{5}{|l|}{ Treatments } \\
\hline Notched & 50 & $27(54 \%)$ & $38 \%$ & $41 \%$ \\
\hline Sound & 50 & $23(46 \%)$ & $46 \%$ & $35 \%$ \\
\hline \multicolumn{5}{|c|}{ Sowing Technique } \\
\hline Buried & 50 & $16(32 \%)$ & $45 \%$ & $36 \%$ \\
\hline Surface & 50 & $34(68 \%)$ & $41 \%$ & $39 \%$ \\
\hline
\end{tabular}


Table 2.4. Acorns damaged solely by weevils and average percentage of cotyledon damaged by weevils.

\begin{tabular}{|c|c|c|c|}
\hline & $\begin{array}{l}\text { Total \# of } \\
\text { Acorns } \\
\text { Examined }\end{array}$ & $\begin{array}{c}\text { \# of Acorns } \\
\text { Damaged by } \\
\text { Weevils }\end{array}$ & $\begin{array}{c}\text { Visual Assessment of } \\
\text { Cotyledon Damaged by } \\
\text { Weevils } \\
\end{array}$ \\
\hline Overall & 2160 & $186(9 \%)$ & $55 \%$ \\
\hline \multicolumn{4}{|l|}{ Site } \\
\hline Glade Run & 186 & $52(28 \%)^{a}$ & $29 \%^{a}$ \\
\hline December & 52 & $10(19 \%)$ & $28 \%$ \\
\hline March & 52 & $13(25 \%)$ & $23 \%$ \\
\hline June & 52 & $29(58 \%)$ & $32 \%$ \\
\hline Lick Run & 186 & $23(12 \%)^{b}$ & $29 \%^{a}$ \\
\hline December & 23 & $11(48 \%)$ & $36 \%$ \\
\hline March & 23 & $4(17 \%)$ & $25 \%$ \\
\hline June & 23 & $8(35 \%)$ & $21 \%$ \\
\hline Laurel Run & 186 & $111(60 \%)^{\mathrm{c}}$ & $73 \%{ }^{b}$ \\
\hline December & 111 & $12(11 \%)$ & $14 \%$ \\
\hline March & 111 & $7(6 \%)$ & $33 \%$ \\
\hline June & 111 & $92(83 \%)$ & $84 \%$ \\
\hline \multicolumn{4}{|l|}{ Time } \\
\hline December & 186 & $33(18 \%)^{a}$ & $26 \%{ }^{a}$ \\
\hline March & 186 & $24(13 \%)^{\mathbf{a}}$ & $22 \%$ \\
\hline June & 186 & $129(69 \%)^{b}$ & $69 \%^{b}$ \\
\hline \multicolumn{4}{|l|}{ Treatments } \\
\hline Notched & 186 & $88(47 \%)^{\mathbf{a}}$ & $64 \%^{a}$ \\
\hline Sound & 186 & $98(53 \%)^{a}$ & $48 \%^{b}$ \\
\hline \multicolumn{4}{|c|}{ Sowing Technique } \\
\hline Buried & 186 & $56(30 \%)^{\mathbf{a}}$ & $44 \%^{a}$ \\
\hline Surface & 186 & $130(70 \%)^{b}$ & $61 \%^{b}$ \\
\hline
\end{tabular}

* Numbers in the same column (broken into the four main treatment effects) followed by a different letter are significantly different at $\mathrm{P}=0.05$. 
Table 2.5. Number of discolored, discolored/weevil damaged and weevil damaged acorns associated with treatments by site.

\begin{tabular}{|l|c|c|c|c|c|c|c|c|c|c|c|c|c|}
\hline \multicolumn{10}{|c|}{ Number of Acorns by Condition, Treatment, and Site } \\
\hline Treatment & \multicolumn{3}{|c|}{ Discolored } & \multicolumn{3}{c|}{ Discolored \& Weevil } & \multicolumn{5}{c|}{ Weevil Damaged } \\
\hline & Glade & Lick & Laurel & Total & \multicolumn{1}{|c|}{ Glade } & Lick & Laure & Total & Glade & Lick & Laurel & Total \\
\hline Notched (N) & $3^{\mathbf{a}}$ & $4^{\mathbf{a}}$ & $78^{\mathbf{b}}$ & $\mathbf{1 5 7}$ & 5 & 4 & 18 & $\mathbf{2 7}$ & 24 & 7 & 57 & $\mathbf{8 8}$ \\
\hline Sound (SD) & 22 & 44 & 32 & $\mathbf{9 8}$ & 6 & 4 & 13 & $\mathbf{2 3}$ & 28 & 16 & 54 & $\mathbf{9 8}$ \\
\hline Buried (B) & 15 & 39 & 42 & $\mathbf{9 6}$ & 2 & 0 & 14 & $\mathbf{1 6}$ & 17 & 8 & 31 & $\mathbf{5 6}$ \\
\hline Surface (SF) & 41 & 50 & 68 & $\mathbf{1 5 9}$ & 9 & 8 & 17 & $\mathbf{3 4}$ & 35 & 15 & 80 & $\mathbf{1 3 0}$ \\
\hline NB & 8 & 18 & 25 & $\mathbf{5 1}$ & 1 & 0 & 6 & $\mathbf{7}$ & 8 & 3 & 18 & $\mathbf{2 9}$ \\
\hline SDB & 7 & 21 & 17 & $\mathbf{4 5}$ & 1 & 0 & 8 & $\mathbf{9}$ & 9 & 5 & 13 & $\mathbf{2 7}$ \\
\hline NSF & $26^{\mathbf{a}}$ & $27^{\mathbf{a}}$ & $53^{\mathbf{b}}$ & $\mathbf{1 0 6}$ & 4 & 4 & 12 & $\mathbf{2 0}$ & 16 & 4 & 39 & $\mathbf{5 9}$ \\
\hline SDSF & 15 & 23 & 15 & $\mathbf{5 3}$ & 5 & 4 & 5 & $\mathbf{1 4}$ & 19 & 11 & 41 & $\mathbf{7 1}$ \\
\hline Total & $\mathbf{5 6}$ & $\mathbf{8 9}$ & $\mathbf{1 1 0}$ & $\mathbf{2 5 5}$ & $\mathbf{1 1}$ & $\mathbf{8}$ & $\mathbf{3 1}$ & $\mathbf{5 0}$ & $\mathbf{5 2}$ & $\mathbf{2 3}$ & $\mathbf{1 1 1}$ & $\mathbf{1 8 6}$ \\
\hline
\end{tabular}

* Numbers in the same row in the discolored columns, followed by a different letter are significantly different at $\mathrm{P}=0.05$.

Table 2.6. Number of acorns with discolored cotyledons by treatments, sites and harvest dates.

\begin{tabular}{|l|c|c|c|c|c|c|c|c|c|c|c|c|}
\hline \multicolumn{9}{|c|}{ Number of Acorns with Discolored Cotyledons } \\
\hline Treatment & \multicolumn{3}{|c|}{ Glade Run } & \multicolumn{3}{c|}{ Lick Run } & \multicolumn{5}{c|}{ Laurel Run } \\
\hline & Dec. & Mar. & June & Total & Dec. & Mar. & June & Total & Dec. & Mar. & June & Total \\
\hline Notched (N) & 5 & 10 & 19 & $\mathbf{3 4}$ & 9 & 14 & 22 & $\mathbf{4 5}$ & 17 & 34 & 27 & $\mathbf{7 8}$ \\
\hline Sound (SD) & 5 & 4 & 13 & $\mathbf{2 2}$ & 4 & 11 & 29 & $\mathbf{4 4}$ & 3 & 8 & 21 & $\mathbf{3 2}$ \\
\hline Buried (B) & 2 & 4 & 9 & $\mathbf{1 5}$ & 10 & 12 & 17 & $\mathbf{3 9}$ & 2 & 6 & 34 & $\mathbf{4 2}$ \\
\hline Surface (SF) & 8 & 10 & 23 & $\mathbf{4 1}$ & 3 & 13 & 34 & $\mathbf{5 0}$ & 18 & 36 & 14 & $\mathbf{6 8}$ \\
\hline NB & 0 & 3 & 5 & $\mathbf{8}$ & 6 & 4 & 8 & $\mathbf{1 8}$ & 2 & 3 & 20 & $\mathbf{2 5}$ \\
\hline SDB & 2 & 1 & 4 & $\mathbf{7}$ & 4 & 8 & 9 & $\mathbf{2 1}$ & 0 & 3 & 14 & $\mathbf{1 7}$ \\
\hline NSF & 5 & 7 & 14 & $\mathbf{2 6}$ & 3 & 10 & 14 & $\mathbf{2 7}$ & 15 & 31 & 7 & $\mathbf{5 3}$ \\
\hline SDSF & 3 & 3 & 9 & $\mathbf{1 5}$ & 0 & 3 & 20 & $\mathbf{2 3}$ & 3 & 5 & 7 & $\mathbf{1 5}$ \\
\hline Total & $\mathbf{1 0}$ & $\mathbf{1 4}$ & $\mathbf{3 2}$ & $\mathbf{5 6}$ & $\mathbf{1 3}$ & $\mathbf{2 5}$ & $\mathbf{5 1}$ & $\mathbf{8 9}$ & $\mathbf{2 0}$ & $\mathbf{4 2}$ & $\mathbf{4 8}$ & $\mathbf{1 1 0}$ \\
\hline
\end{tabular}

Table 2.7. Germination rates for all three sites by treatment and harvest date.

\begin{tabular}{|l|c|c|c|c|c|c|c|c|c|}
\hline \multicolumn{7}{|c|}{ Germination Rates by Site and Time of Year } \\
\hline Treatment & \multicolumn{3}{|c|}{ Glade Run } & \multicolumn{3}{c|}{ Lick Run } & \multicolumn{3}{c|}{ Laurel Run } \\
\hline & December & March & June & December & March & June & December & March & June \\
\hline Notched (N) & $11 \%$ & $68 \%$ & $99 \%$ & $3 \%$ & $92 \%$ & $93 \%$ & $2 \%$ & $73 \%$ & $54 \%$ \\
\hline Sound (SD) & $19 \%$ & $78 \%$ & $99 \%$ & $2 \%$ & $93 \%$ & $93 \%$ & $5 \%$ & $88 \%$ & $70 \%$ \\
\hline Buried (B) & $23 \%$ & $79 \%$ & $100 \%$ & $3 \%$ & $97 \%$ & $98 \%$ & $6 \%$ & $99 \%$ & $82 \%$ \\
\hline Surface (SF) & $7 \%$ & $67 \%$ & $98 \%$ & $2 \%$ & $88 \%$ & $88 \%$ & $1 \%$ & $62 \%$ & $43 \%$ \\
\hline NB & $18 \%$ & $78 \%$ & $100 \%$ & $3 \%$ & $100 \%$ & $100 \%$ & $2 \%$ & $100 \%$ & $77 \%$ \\
\hline SDB & $3 \%$ & $58 \%$ & $98 \%$ & $2 \%$ & $83 \%$ & $87 \%$ & $2 \%$ & $48 \%$ & $32 \%$ \\
\hline NSF & $30 \%$ & $80 \%$ & $100 \%$ & $2 \%$ & $93 \%$ & $95 \%$ & $10 \%$ & $98 \%$ & $87 \%$ \\
\hline SDSF & $8 \%$ & $75 \%$ & $98 \%$ & $2 \%$ & $93 \%$ & $90 \%$ & $0 \%$ & $75 \%$ & $53 \%$ \\
\hline Overall \% & $\mathbf{1 5 \%}$ & $\mathbf{7 3 \%}$ & $\mathbf{9 9 \%}$ & $\mathbf{2 \%}$ & $\mathbf{9 3 \%}$ & $\mathbf{9 3 \%}$ & $\mathbf{3 \%}$ & $\mathbf{8 0 \%}$ & $\mathbf{6 2 \%}$ \\
\hline
\end{tabular}


Table 2.8. Germination rates for December-harvested acorn by site, treatment, and condition.

\begin{tabular}{|c|c|c|c|c|c|c|c|c|c|c|c|c|c|c|c|}
\hline \multicolumn{16}{|c|}{ Germination Rates for December-Harvested Acorns } \\
\hline Treatment & \multicolumn{5}{|c|}{ Glade Run } & \multicolumn{5}{|c|}{ Lick Run } & \multicolumn{5}{|c|}{ Laurel Run } \\
\hline & $\mathbf{S}^{*}$ & $\mathbf{D}^{* * *}$ & D \& $\mathbf{W}^{+}$ & $\mathbf{W}^{++}$ & $\mathbf{O}^{+++}$ & $\mathbf{S}^{*}$ & $\mathbf{D}^{* * *}$ & D \& $\mathbf{W}^{+}$ & $\mathbf{W}^{++}$ & $\mathbf{O}^{+++}$ & $\mathbf{S}^{*}$ & $\mathbf{D}^{* * *}$ & $\mathbf{D} \& \mathbf{W}^{+}$ & $\mathbf{W}^{++}$ & $\mathbf{O}^{+++}$ \\
\hline Notched $(\mathrm{N})$ & $8 \%$ & $20 \%$ & $\mathrm{NA}^{\mathrm{Y}}$ & $33 \%$ & $11 \%$ & $3 \%$ & $0 \%$ & $\mathrm{NA}^{\mathrm{Y}}$ & $0 \%$ & $3 \%$ & $2 \%$ & $0 \%$ & $\mathrm{NA}^{\mathrm{Y}}$ & $0 \%$ & $2 \%$ \\
\hline Sound (SD) & $17 \%$ & $20 \%$ & $\mathrm{NA}^{\mathrm{Y}}$ & $67 \%$ & $19 \%$ & $0 \%$ & $0 \%$ & $\mathrm{NA}^{\mathrm{Y}}$ & $11 \%$ & $2 \%$ & $5 \%$ & $0 \%$ & $\mathrm{NA}^{\mathrm{Y}}$ & $0 \%$ & $5 \%$ \\
\hline Buried (B) & $21 \%$ & $50 \%$ & $\mathrm{NA}^{\mathrm{Y}}$ & $57 \%$ & $23 \%$ & $2 \%$ & $0 \%$ & $\mathrm{NA}^{\mathrm{Y}}$ & $25 \%$ & $3 \%$ & $6 \%$ & $0 \%$ & $\mathrm{NA}^{\mathrm{Y}}$ & $0 \%$ & $6 \%$ \\
\hline Surface (SF) & $5 \%$ & $13 \%$ & $\mathrm{NA}^{\mathrm{Y}}$ & $0 \%$ & $7 \%$ & $1 \%$ & $0 \%$ & $\mathrm{NA}^{\mathrm{Y}}$ & $0 \%$ & $2 \%$ & $1 \%$ & $0 \%$ & $\mathrm{NA}^{\mathrm{Y}}$ & $0 \%$ & $1 \%$ \\
\hline $\mathrm{NB}$ & $14 \%$ & $\mathrm{NA}^{\mathrm{Y}}$ & $\mathrm{NA}^{\mathrm{Y}}$ & $50 \%$ & $18 \%$ & $4 \%$ & $0 \%$ & $\mathrm{NA}^{\mathrm{Y}}$ & $0 \%$ & $3 \%$ & $2 \%$ & $0 \%$ & $\mathrm{NA}^{\mathrm{Y}}$ & $0 \%$ & $2 \%$ \\
\hline SDB & $2 \%$ & $40 \%$ & $\mathrm{NA}^{\mathrm{Y}}$ & $0 \%$ & $3 \%$ & $2 \%$ & $0 \%$ & $\mathrm{NA}^{\mathrm{Y}}$ & $0 \%$ & $2 \%$ & $2 \%$ & $0 \%$ & $\mathrm{NA}^{\mathrm{Y}}$ & $0 \%$ & $2 \%$ \\
\hline NSF & $27 \%$ & $50 \%$ & $\mathrm{NA}^{\mathrm{Y}}$ & $67 \%$ & $30 \%$ & $0 \%$ & $0 \%$ & $\mathrm{NA}^{\mathrm{Y}}$ & $33 \%$ & $2 \%$ & $10 \%$ & $\mathrm{NA}^{\mathrm{Y}}$ & $\mathrm{NA}^{\mathrm{Y}}$ & $0 \%$ & $10 \%$ \\
\hline SDSF & $7 \%$ & $0 \%$ & $\mathrm{NA}^{\mathrm{Y}}$ & $0 \%$ & $8 \%$ & $0 \%$ & $\mathrm{NA}^{\mathrm{Y}}$ & $\mathrm{NA}^{\mathrm{Y}}$ & $0 \%$ & $2 \%$ & $0 \%$ & $0 \%$ & $\mathrm{NA}^{\mathrm{Y}}$ & $0 \%$ & $0 \%$ \\
\hline Overall \% & $13 \%$ & $30 \%$ & $\mathbf{N A}^{\mathrm{Y}}$ & $44 \%$ & $15 \%$ & $1 \%$ & 0\% & $\mathbf{N A}^{\mathrm{Y}}$ & $9 \%$ & $2 \%$ & $4 \%$ & $0 \%$ & $\mathbf{N A}^{Y}$ & 0\% & $4 \%$ \\
\hline${ }^{+}$Discoll & & & & & & & & & able & & & & & & \\
\hline
\end{tabular}

Table 2.9. Germination rates for March-harvested acorn by site, treatment, and condition.

\begin{tabular}{|c|c|c|c|c|c|c|c|c|c|c|c|c|c|c|c|}
\hline \multicolumn{16}{|c|}{ Germination Rates for March-Harvested Acorns } \\
\hline \multirow[t]{2}{*}{ Treatment } & \multicolumn{5}{|c|}{ Glade Run } & \multicolumn{5}{|c|}{\begin{tabular}{|c|} 
Lick Run \\
\end{tabular}} & \multicolumn{5}{|c|}{\begin{tabular}{|l} 
Laurel Run \\
\end{tabular}} \\
\hline & $\mathbf{S}^{*}$ & $\mathbf{D}^{* *}$ & D \& $\mathbf{W}^{+}$ & $\mathbf{W}^{++}$ & $\mathbf{O}^{+++}$ & $\mathbf{S}^{*}$ & $\mathbf{D}^{* * *}$ & $\mathbf{D} \boldsymbol{\&} \mathbf{W}^{+}$ & $\mathbf{W}^{++}$ & $\mathbf{O}^{+++}$ & $\mathbf{S}^{*}$ & $\mathbf{D}^{* *}$ & D \& $\mathbf{W}^{+}$ & $\mathbf{W}^{++}$ & $\mathbf{O}^{+++}$ \\
\hline Notched $(\mathrm{N})$ & $89 \%$ & $70 \%$ & $\mathrm{NA}^{\mathrm{Y}}$ & $100 \%$ & $68 \%$ & $91 \%$ & $79 \%$ & $\mathrm{NA}^{\mathrm{Y}}$ & $100 \%$ & $92 \%$ & $90 \%$ & $29 \%$ & $0 \%$ & $100 \%$ & $73 \%$ \\
\hline Sound (SD) & $97 \%$ & $75 \%$ & $100 \%$ & $86 \%$ & $78 \%$ & $98 \%$ & $45 \%$ & $\mathrm{NA}^{\mathrm{Y}}$ & $100 \%$ & $93 \%$ & $89 \%$ & $75 \%$ & $\mathrm{NA}^{\mathrm{Y}}$ & $80 \%$ & $88 \%$ \\
\hline Buried (B) & $99 \%$ & $100 \%$ & $\mathrm{NA}^{\mathrm{Y}}$ & $100 \%$ & $79 \%$ & $100 \%$ & $67 \%$ & $\mathrm{NA}^{\mathrm{Y}}$ & $100 \%$ & $97 \%$ & $100 \%$ & $83 \%$ & $0 \%$ & $100 \%$ & $99 \%$ \\
\hline Surface (SF) & $87 \%$ & $60 \%$ & $100 \%$ & $86 \%$ & $67 \%$ & $90 \%$ & $62 \%$ & $\mathrm{NA}^{\mathrm{Y}}$ & $100 \%$ & $88 \%$ & $75 \%$ & $31 \%$ & $\mathrm{NA}^{\mathrm{Y}}$ & $67 \%$ & $62 \%$ \\
\hline NB & $98 \%$ & $100 \%$ & $\mathrm{NA}^{\mathrm{Y}}$ & $100 \%$ & $78 \%$ & $100 \%$ & $100 \%$ & $\mathrm{NA}^{\mathrm{Y}}$ & $\mathrm{NA}^{\mathrm{Y}}$ & $100 \%$ & $100 \%$ & $100 \%$ & $0 \%$ & $100 \%$ & $100 \%$ \\
\hline SDB & $80 \%$ & $57 \%$ & $\mathrm{NA}^{\mathrm{Y}}$ & $100 \%$ & $58 \%$ & $82 \%$ & $70 \%$ & $\mathrm{NA}^{\mathrm{Y}}$ & $100 \%$ & $83 \%$ & $71 \%$ & $23 \%$ & $\mathrm{NA}^{\mathrm{Y}}$ & $100 \%$ & $48 \%$ \\
\hline NSF & $100 \%$ & $100 \%$ & $\mathrm{NA}^{\mathrm{Y}}$ & $100 \%$ & $80 \%$ & $100 \%$ & $50 \%$ & $\mathrm{NA}^{\mathrm{Y}}$ & $100 \%$ & $93 \%$ & $100 \%$ & $67 \%$ & $\mathrm{NA}^{\mathrm{Y}}$ & $100 \%$ & $98 \%$ \\
\hline SDSF & $94 \%$ & $67 \%$ & $100 \%$ & $75 \%$ & $75 \%$ & $96 \%$ & $33 \%$ & $\mathrm{NA}^{\mathrm{Y}}$ & $100 \%$ & $93 \%$ & $77 \%$ & $80 \%$ & $\mathrm{NA}^{\mathrm{Y}}$ & $50 \%$ & $75 \%$ \\
\hline Overall \% & $93 \%$ & $71 \%$ & $100 \%$ & $92 \%$ & $73 \%$ & $95 \%$ & $64 \%$ & $\mathbf{N A}^{\mathrm{Y}}$ & $100 \%$ & $93 \%$ & $89 \%$ & $38 \%$ & $\mathbf{0 \%}$ & $86 \%$ & $80 \%$ \\
\hline $\begin{array}{r}\text { Discol } \\
+ \\
+\end{array}$ & & Ions & & & & & & ot $\mathrm{Ar}$ & able & & & & & & \\
\hline
\end{tabular}

Table 2.10. Germination rate for March and June-harvested acorns with regard to amount of cotyledon discoloration.

\begin{tabular}{|c|c|c|c|c|c|c|}
\hline \multicolumn{7}{|c|}{ Germination Rate } \\
\hline & \multicolumn{3}{|c|}{ March } & \multicolumn{3}{c|}{ June } \\
\hline Discoloration & Glade & Lick & Laurel & Glade & Lick & Laurel \\
\hline $0-25 \%$ & $78 \%$ & $57 \%$ & $91 \%$ & $100 \%$ & $94 \%$ & $50 \%$ \\
\hline $26-50 \%$ & $75 \%$ & $38 \%$ & $67 \%$ & $100 \%$ & $70 \%$ & $55 \%$ \\
\hline $51-75 \%$ & $0 \%$ & $0 \%$ & $67 \%$ & $100 \%$ & $40 \%$ & $80 \%$ \\
\hline $76-100 \%$ & $0 \%$ & $40 \%$ & $25 \%$ & $100 \%$ & $77 \%$ & $57 \%$ \\
\hline
\end{tabular}


Table 2.11. Germination rates for June-harvested acorn by site, treatment, and condition.

\begin{tabular}{|c|c|c|c|c|c|c|c|c|c|c|c|c|c|c|c|}
\hline \multicolumn{16}{|c|}{ Germination Rates for June-Harvested Acorns } \\
\hline \multirow[t]{2}{*}{ Treatment } & \multicolumn{5}{|c|}{ Glade Run } & \multicolumn{5}{|c|}{ Lick Run } & \multicolumn{5}{|c|}{ Laurel Run } \\
\hline & $\mathbf{S}^{*}$ & $\mathbf{D}^{* * *}$ & $\mathbf{D} \& \mathbf{W}^{+}$ & $\mathbf{W}^{++}$ & $\mathbf{O}^{+++}$ & $\mathbf{S}^{*}$ & $\mathbf{D}^{* * *}$ & $\mathbf{D} \& \mathbf{W}^{+}$ & $\mathbf{W}^{++}$ & $\mathbf{O}^{+++}$ & $\mathbf{S}^{*}$ & $\mathbf{D}^{* * *}$ & D \& $\mathbf{W}^{+}$ & $\mathbf{W}^{++}$ & $\mathbf{O}^{+++}$ \\
\hline Notched $(\mathrm{N})$ & $99 \%$ & $95 \%$ & $100 \%$ & $100 \%$ & $99 \%$ & $98 \%$ & $73 \%$ & $75 \%$ & $100 \%$ & $93 \%$ & $81 \%$ & $63 \%$ & $29 \%$ & $12 \%$ & $54 \%$ \\
\hline Sound (SD) & $99 \%$ & $100 \%$ & $100 \%$ & $100 \%$ & $99 \%$ & $96 \%$ & $79 \%$ & $100 \%$ & $100 \%$ & $93 \%$ & $75 \%$ & $62 \%$ & $69 \%$ & $24 \%$ & $70 \%$ \\
\hline Buried (B) & $100 \%$ & $100 \%$ & $100 \%$ & $100 \%$ & $100 \%$ & $99 \%$ & $88 \%$ & $\mathrm{NA}^{\mathrm{Y}}$ & $100 \%$ & $98 \%$ & $94 \%$ & $82 \%$ & $100 \%$ & $9 \%$ & $82 \%$ \\
\hline Surfa & $97 \%$ & $95 \%$ & $100 \%$ & $100 \%$ & $98 \%$ & $94 \%$ & $71 \%$ & $88 \%$ & $100 \%$ & $88 \%$ & $32 \%$ & $14 \%$ & $6 \%$ & $20 \%$ & $43 \%$ \\
\hline NB & $100 \%$ & $100 \%$ & $100 \%$ & $100 \%$ & $100 \%$ & $100 \%$ & $100 \%$ & $\mathrm{NA}^{\mathrm{Y}}$ & $\mathrm{NA}^{\mathrm{Y}}$ & $100 \%$ & $95 \%$ & $80 \%$ & $100 \%$ & $7 \%$ & $77 \%$ \\
\hline SDB & $97 \%$ & $93 \%$ & $100 \%$ & $100 \%$ & $98 \%$ & $95 \%$ & $57 \%$ & $75 \%$ & $100 \%$ & $87 \%$ & $20 \%$ & $14 \%$ & $0 \%$ & $14 \%$ & $32 \%$ \\
\hline $\mathrm{NSF}$ & $100 \%$ & $100 \%$ & $100 \%$ & $100 \%$ & $100 \%$ & $98 \%$ & $78 \%$ & $\mathrm{NA}^{\mathrm{Y}}$ & $100 \%$ & $95 \%$ & $93 \%$ & $86 \%$ & $100 \%$ & $13 \%$ & $87 \%$ \\
\hline SDSF & $97 \%$ & $100 \%$ & $100 \%$ & $100 \%$ & $98 \%$ & $94 \%$ & $80 \%$ & $100 \%$ & $100 \%$ & $90 \%$ & $36 \%$ & $14 \%$ & $20 \%$ & $26 \%$ & $53 \%$ \\
\hline Overall \% & $99 \%$ & $97 \%$ & $100 \%$ & $100 \%$ & $99 \%$ & $97 \%$ & $76 \%$ & $88 \%$ & $100 \%$ & $93 \%$ & $77 \%$ & $63 \%$ & $47 \%$ & $17 \%$ & $62 \%$ \\
\hline${ }^{+}$Discol & 1. & u & $\mathrm{il} \mathrm{Da}$ & & & & & Not An & icab & & & & & & \\
\hline
\end{tabular}

Table 2.12. Average seedling rating for June harvested acorns by site and acorn condition.

\begin{tabular}{|l|c|c|c|c|}
\hline \multicolumn{5}{|c|}{$\begin{array}{c}\text { Average Seedling Rating for June Harvested Acorns by Site } \\
\text { and Acorn Condition }\end{array}$} \\
\hline Condition & Glade Run & Lick Run & Laurel Run & Overall \\
\hline Undamaged & 1.55 & 1.64 & 0.77 & $\mathbf{1 . 3 2}$ \\
\hline Discolored & 1.66 & 1.47 & 1.25 & $\mathbf{1 . 4 6}$ \\
\hline Discolored and Weevil & 1.30 & 1.25 & 0.87 & $\mathbf{1 . 1 4}$ \\
\hline Weevil Damaged & 0.28 & 1.00 & 0.40 & $\mathbf{0 . 5 6}$ \\
\hline Overall & $\mathbf{1 . 2 0}$ & $\mathbf{1 . 3 4}$ & $\mathbf{0 . 8 2}$ & $\mathbf{1 . 1 2}$ \\
\hline
\end{tabular}

Table 2.13. Average seedling ratings for June-harvested acorns by site and treatment.

\begin{tabular}{|l|c|c|c|c|}
\hline \multicolumn{6}{|c|}{$\begin{array}{c}\text { Average Seedling Ratings for June-Harvested Acorns } \\
\text { by Site and Treatments }\end{array}$} \\
\hline Treatments & Glade Run & Lick Run & Laurel Run & Overall \\
\hline Notched (N) & $1.55^{\text {a }}$ & $1.54^{\text {a }}$ & $0.70^{\text {b }}$ & $\mathbf{1 . 2 6}$ \\
\hline Sound (SD) & 1.49 & 1.60 & 1.01 & $\mathbf{1 . 3 7}$ \\
\hline Buried (B) & 1.53 & 1.73 & 1.43 & $\mathbf{1 . 5 6}^{\text {a }}$ \\
\hline Surface (SF) & 1.51 & 1.40 & 0.27 & $\mathbf{1 . 0 6}^{\text {b }}$ \\
\hline NB & 1.50 & 1.87 & 1.28 & $\mathbf{1 . 5 5}$ \\
\hline SDB & 1.61 & 1.22 & 1.57 & $\mathbf{1 . 4 7}$ \\
\hline NSF & 1.57 & 1.60 & 0.10 & $\mathbf{1 . 0 9}$ \\
\hline SDSF & 1.42 & 1.60 & 0.44 & $\mathbf{1 . 1 5}$ \\
\hline Overall & $\mathbf{1 . 5 2}^{\mathrm{a}}$ & $\mathbf{1 . 5 7}^{\mathrm{a}}$ & $\mathbf{0 . 8 5}$ & $\mathbf{1 . 3 1}$ \\
\hline
\end{tabular}

*Numbers in the same row followed by a different letter are significantly different at $\mathrm{P}=$ 0.05 . 
Figure 2.1. Map of Glade and Lick Run study site locations.

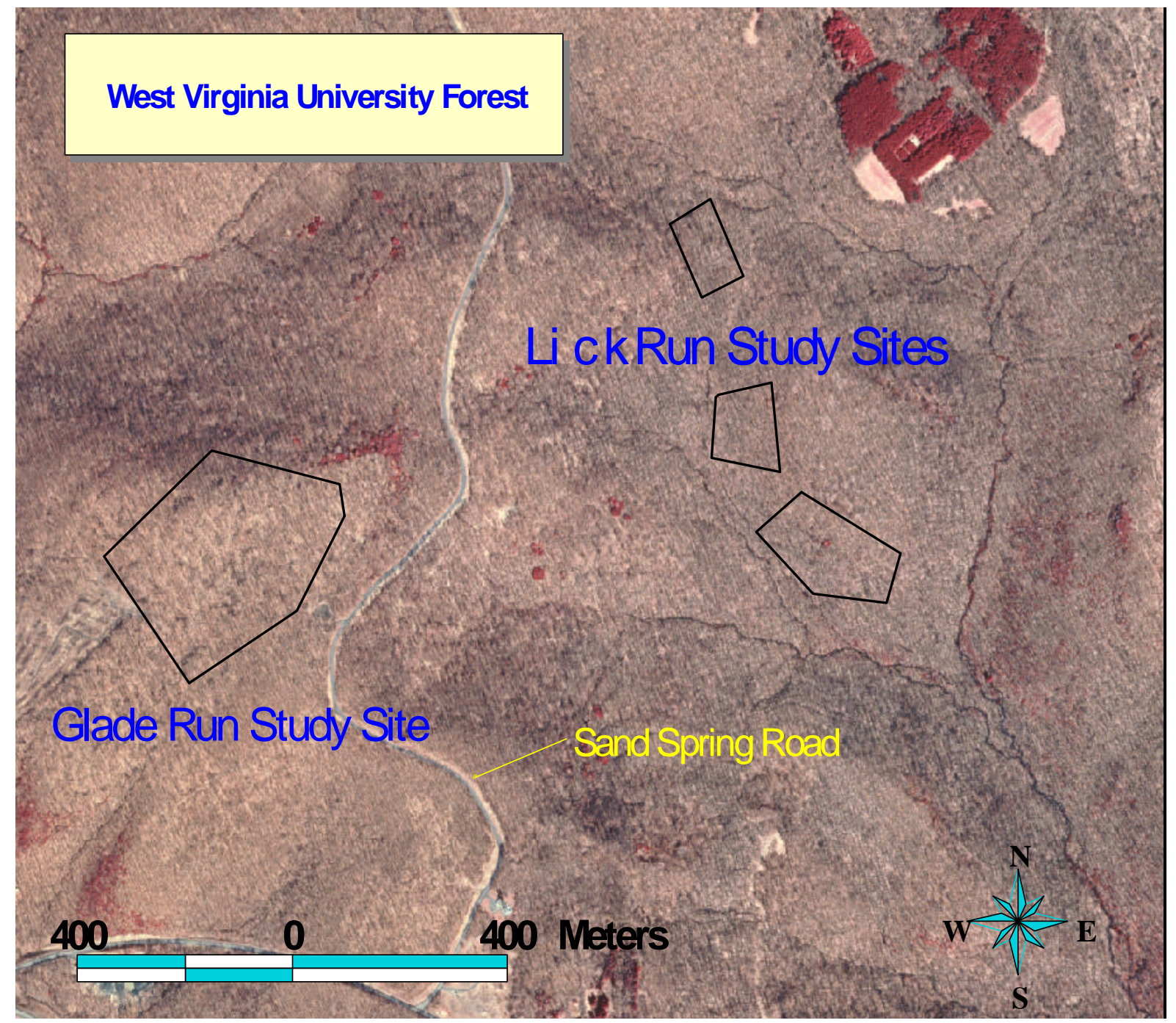


Figure 2.2. Map of Laurel Run study site locations.

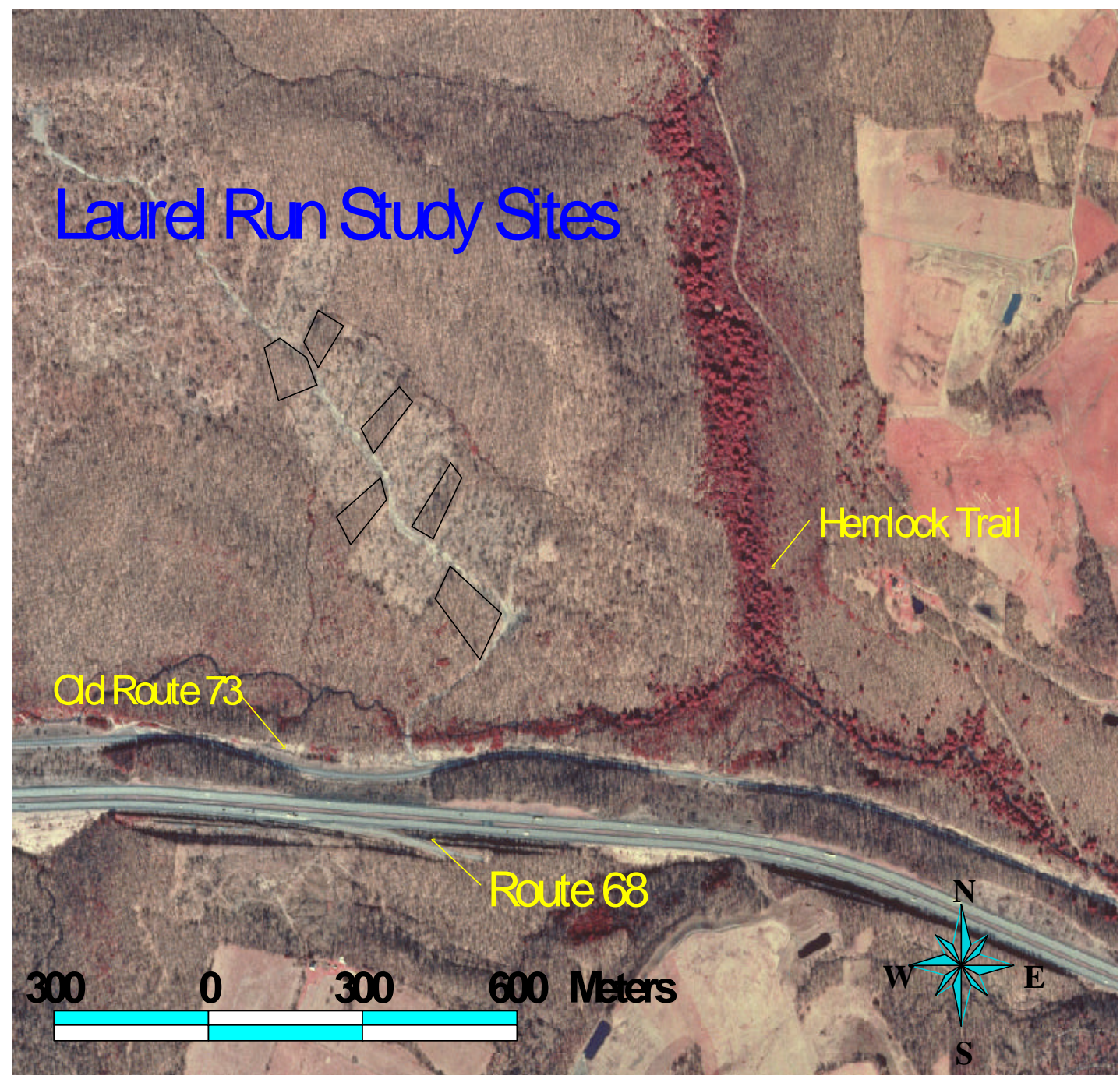


Figure 2.3. Acorn placement in cages at each plot. (Notched acorns were placed on the left side while non-notched were placed on the right side of the cage. Top left and bottom right acorns were buried while bottom left and top right acorns were placed on the surface.)

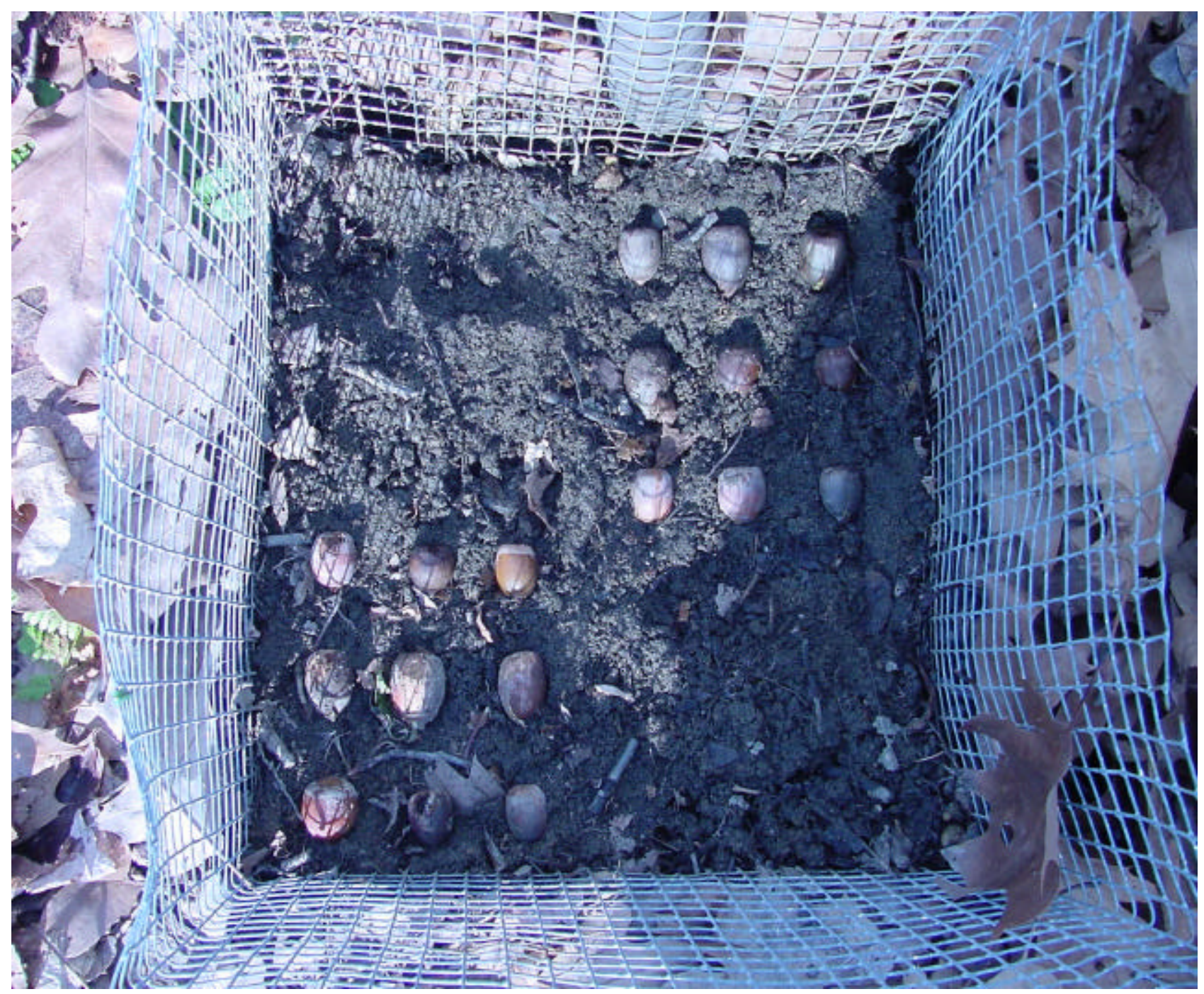


Figure 2.4: Frequency of Fungi Isolated From Acorns with Discolored Cotyledons

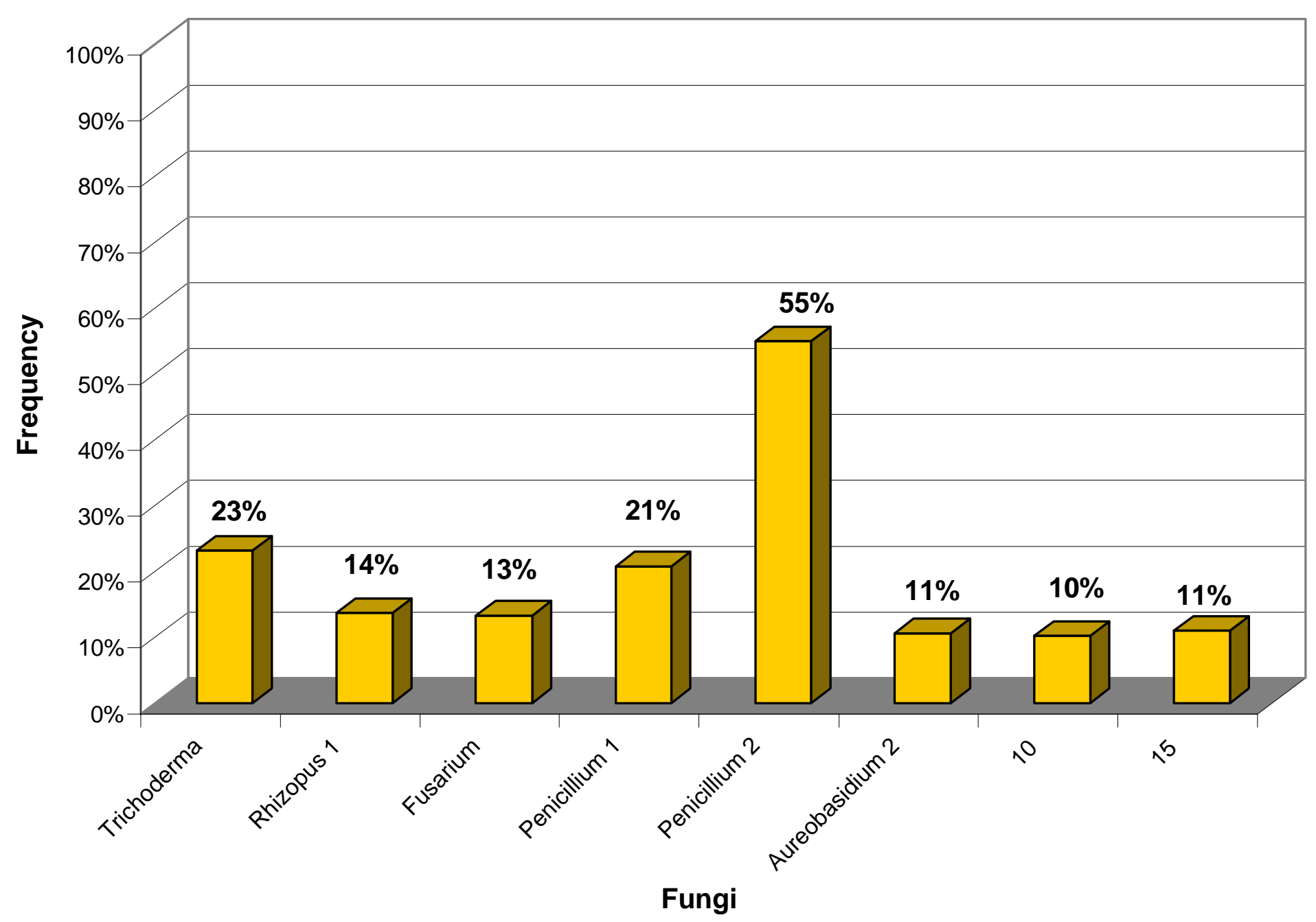


Figure 2.5: Frequency of Fungi Isolated From Acorns with Discolored Cotyledons and Weevil Damage

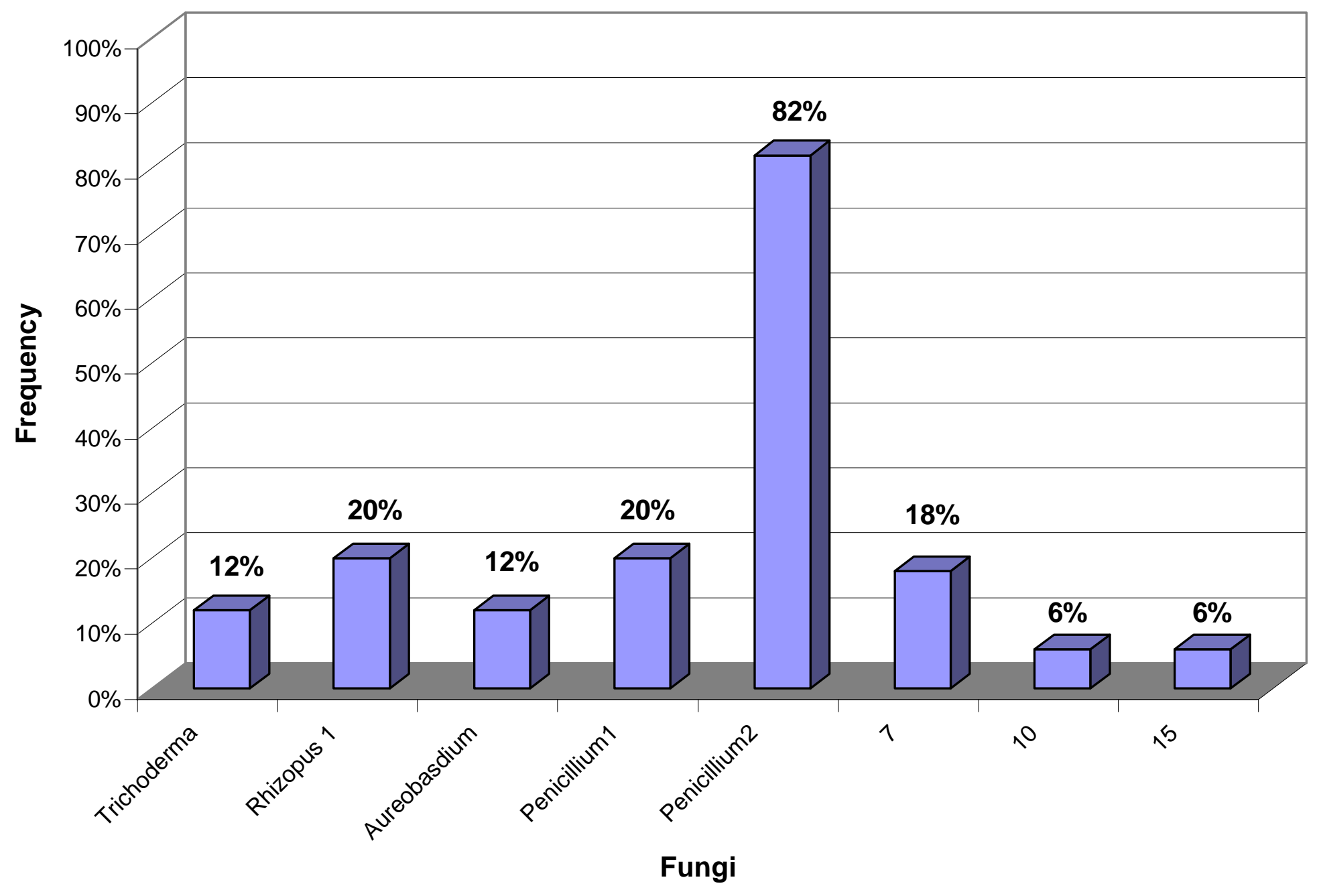


Figure 2.6: Frequency of Fungi Isolated from Acorns with Weevil Damage from all Sites and Harvest Dates

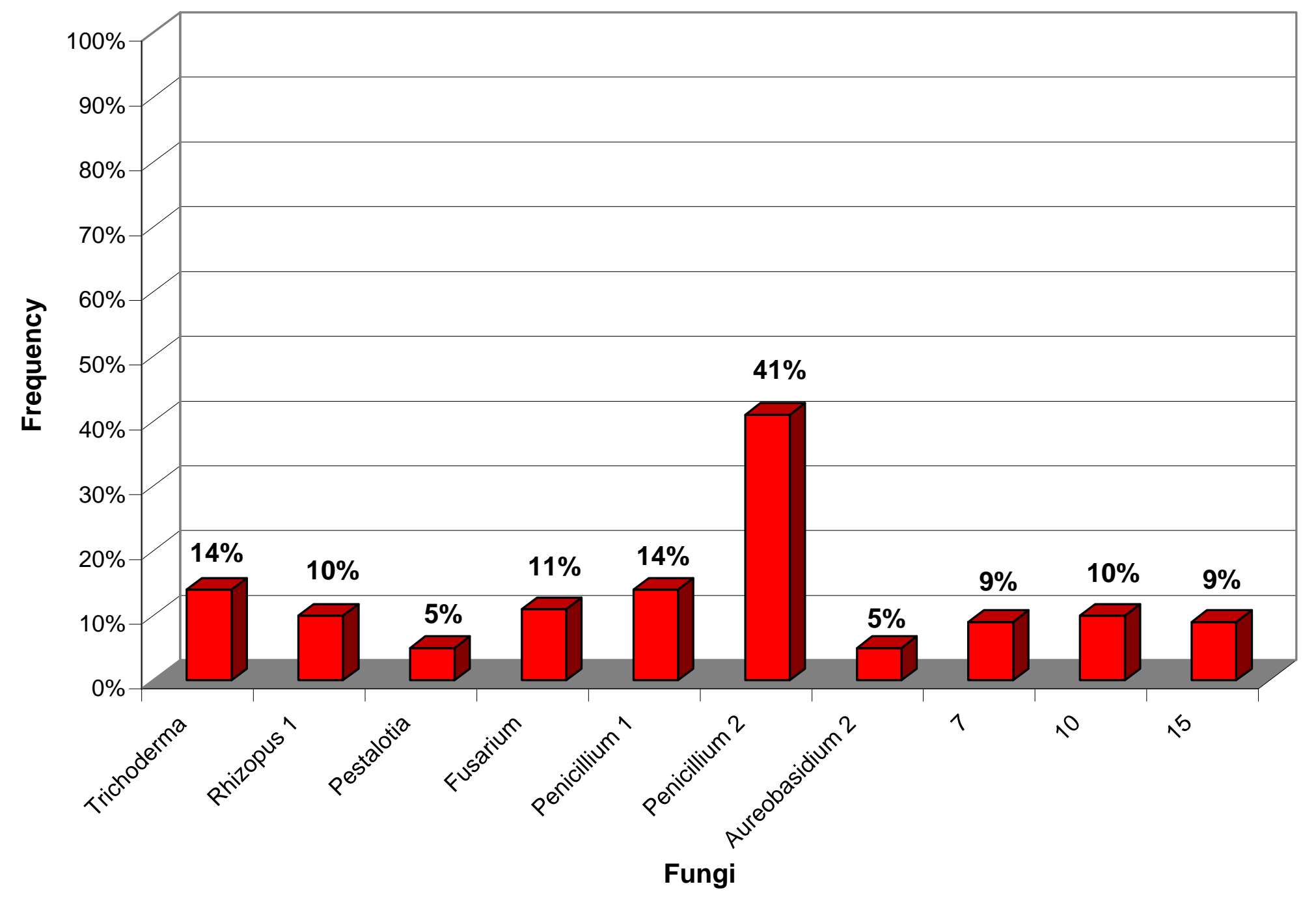


Figure 2.7: Frequency of Fungi Associated with Acorn Shells at all Sites

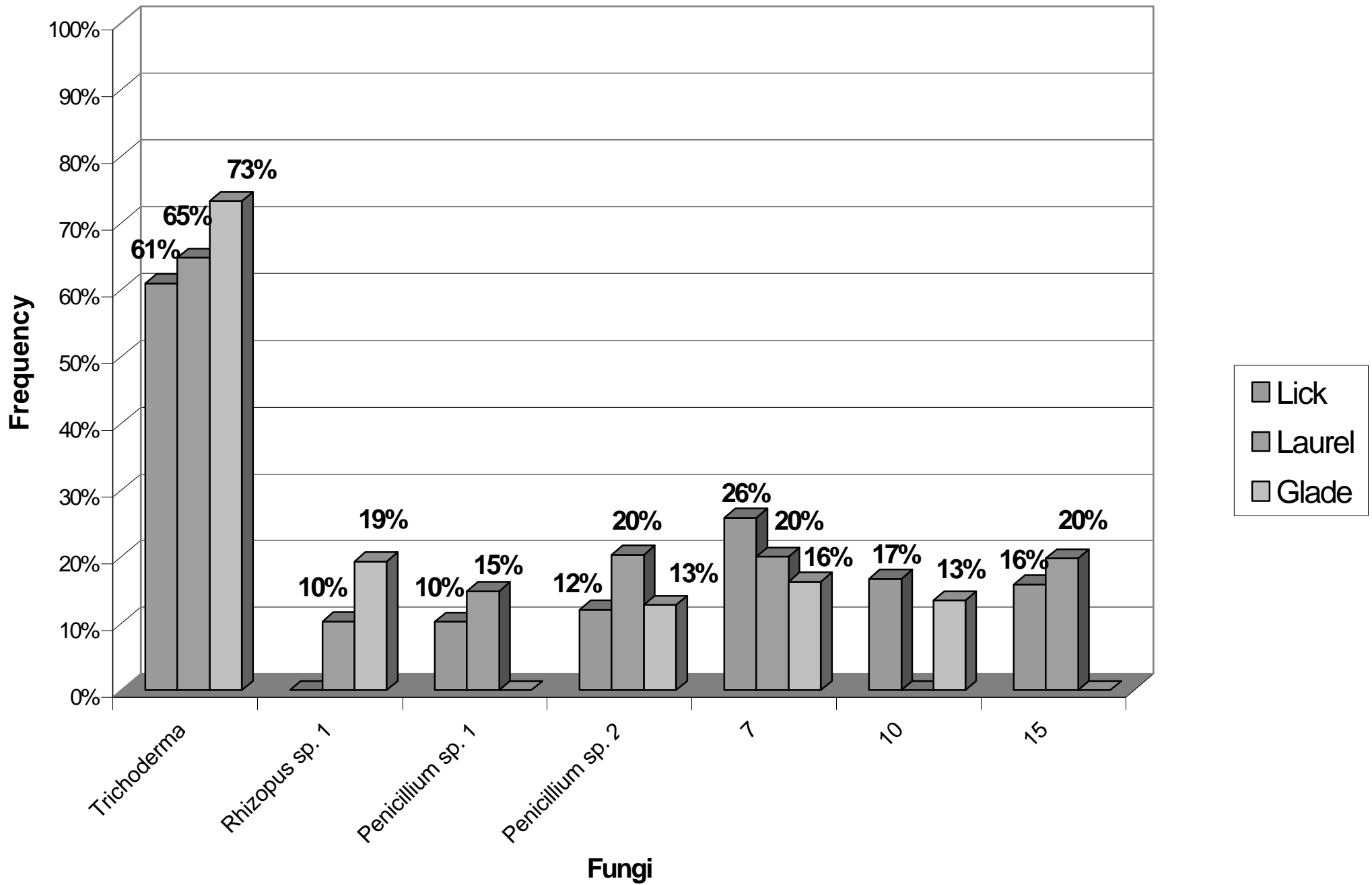




\section{LITERATURE CITED}

Barnett, H.L. and B.B. Hunter. 1972. Illustrated Genera of imperfect fungi. Burgess Publishing Co. Minneapolis, MN.

Delatour, C., and M. Morelet. 1979. La pourriture noire des glands. Rev. Forestiere Francaise 31:101-115 [Seed Abstracts. 1980. 3:1737]

Dorsey, C.K., E.H. Tryon. and K.L. Carvell. 1962. Insect damage to acorns in West Virginia and control studies using granular systematic insectidies. Journal of Economic Entomology 55: 885-888.

Eyre, F.H., ed. 1980. Forest cover types of the United States and Canada. Society of American Foresters, Washington, DC. 148 pp.

Fenneman, N.M. 1938. Physiography of the Eastern United States. McGraw-Hill, New York, New York. 714 pp.

Gibson, L.P. 1964. Biology and life history of acorn-infesting weevils of the genus Conotrachelus (Coleoptera: Curculioidae). Ann. Entomology Society of America 57:521-526.

Gibson, L.P. 1969. Monograph of the genus Curculio in the New World (Coleoptera: Curculioidae): Part I. United States and Canada. Miscellaneous Publication Entomology Society of America 6:241-285.

Gibson, L.P. 1972. Insects that damage white oak acorns. USDA Forest Service Research Paper NE-220 7pp.

Gribko, L.S. and W. E. Jones. 1995. Test of the float method of assessing northern red oak acorn viability. Tree Planter's Notes 46:143-147.

Gribko, L.S. and D. M. Washington. 2001. Viability of northern red oak acorns infested by Curculio weevil larvae. Unpublished Data.

Hicks, R.R., Jr. 1998. Ecology and Management of Central Hardwood Forests. John Wiley and Sons. New York. 412 pp.

National Oceanic and Atmospheric Administration. 1999. National Climatological Data: Morgantown, West Virginia. U. S. Department of Commerce, Washington, D. C., USA.

Raper, K.B. and C. Thom 1949. A Manual of the Penicillia. Williams and Wilkins Company, Baltimore, MD. 875 pp.

Swiecki, T.J., E. A, Bernhardt, and R.A. Arnold. 1991. Insect and disease impacts on blue oak acorns and seedlings. Proceeding on the symposium on oak woodlands and hardwood 
rangeland management; October 31 - November 2 1990, Davis, CA. USDA Forest Service General Technical Report PSW-126. pp. 149-155.

Vozzo, J.A. 1984. Insects and fungi associated with acorns of Quercus sp. USDA Forest Service General Technical Report S-40-43 p. Southern Forest Experimental Station, Starkville, Mississippi.

Winston, P.W. 1956. The acorn microsphere, with special reference to arthropods. Ecology 37:120-132. 


\section{Chapter 3: \\ Inoculation and Germination of Northern Red Oak Acorns}

\section{INTRODUCTION}

The ability to cause infection is an important component to determine the pathogenicity of a microorganism (i.e. completion of Koch's Postulates). To determine if the fungi previously cultured from northern red oak acorns could colonize and damage an acorn's cotyledon, a series of inoculations were made to "healthy" acorns. The five fungi most frequently isolated from the three study sites were selected as inocula for this test. These fungi included one species of Rhizopus, Trichoderma, Fusarium, and two species of Penicillium tentatively identified as Penicillium chermesinum and Penicillium terretre. Treatments included the five fungi injected alone, a combination of all five fungi, a $0.05 \%$ tween 20 in sterilized, distilled water control, and Cordyceps militaris, an insect pathogen that had no suspected pathogenicity to oak. Each treatment was replicated 30 times. A subset of acorns was cultured after 10, 20 and 30 days.

\section{MATERIALS AND METHODS}

\section{Field Methods}

Northern red oak acorns used in this test were collected at the West Virginia University Forest (WVUF) in late September and early October near the Lick Run site described previously. Due

to a poor seed crop year, the collection of acorns was limited to approximately five trees near the Lick Run study site from the previous experiment. Acorns were soaked in water for 24 hours and float-tested in water to determine their condition (Gribko and Jones 1995). Only acorns that were apparently sound, sank during the float test and had no obvious signs of insect or microorganism damage were used for this study. Because northern red oak acorns require a cold stratification period before they will germinate, (Schopmeyer 1974) they were stored at approximately $2^{\circ} \mathrm{C}$ in trays covered with moist newspaper for approximately 4 months.

\section{Laboratory Procedures}

Spores of each of the five fungal isolates, from the previous experiment, were washed from the agar surface and suspended in sterile distilled water amended with $0.05 \%$ tween 20 to reduce surface tension permitting the suspension of spores. Spore concentrations were adjusted to $5 \mathrm{x}$ 
$10^{5}$ spores per milliliter. Because sporulation by the Fusarium isolate was lost, hyphal fragments were used instead of spores. This concentration was adjusted to 4.5 fragments $x 10^{5}$ per milliliter. The acorns were inoculated by making an injection with a sterile 18-gauge hypodermic needle at the edge of the hilum. The inoculum $(\sim 1 \mathrm{ml})$ was delivered to the inside of the acorn cotyledon with a sterile $5 \mathrm{ml}$ syringe. A separate syringe was used for each of the eight treatments to prevent cross contamination. Two hundred and forty acorns were used in which thirty acorns were inoculated per treatment inoculum.

The acorns were then incubated in a propagation tray containing moist newspaper that was placed in the bottom of a greenhouse tray $(53.34-\mathrm{cm}$ by $27.3-\mathrm{cm})$ (Figure 3.1). Sterilized peat moss was then added and sprayed lightly with distilled water to moisten the peat moss. Acorns were elevated above the surface of the peat moss with hardware cloth. A clear, plastic propagation dome was placed on top of the tray to limit air borne contamination from the laboratory and maintain high humidity conditions for germination. Acorns placed on the hardware cloth were incubated at room temperature $\left(23-25^{\circ} \mathrm{C}\right)$ under florescent light in a 13:11 hour photoperiod for 10, 20, and 30 days. All acorns were examined for germination however; only the acorns from the 30-day period were expected to germinate.

A subset of acorns were removed and dissected after each inoculation period to observe cotyledon discoloration and to remove cotyledons for culturing. Ten acorns were removed from each inoculum treatment and cultured after 10, 20 and 30 days. A visual estimate of cotyledon discoloration was determined and three pieces of the cotyledon were plated onto PDA. All cotyledons, regardless of whether or not they had discolored cotyledons, were cultured and incubated at room temperature under florescent light in a 13:11 hour photoperiod. In many cases, multiple fungi were isolated from a single acorn cotyledon. Cultures were evaluated to ascertain if the fungi resembled those from the initial inoculum, thereby providing evidence to confirm a relationship.

The acorns that were dissected after the 10-day period contained cotyledons with discoloration, including those that were associated with both controls. Therefore, 50 acorns from both groups, floaters and sinkers, were randomly selected and cut open to test accuracy of the float test. The 
following conditions were noted: 1) percent of cotyledon discolored; 2) percent of cotyledon with weevil damage; 3) number of weevils; and, 4) number of exit holes. The 50 sinkers, those assumed to be free of fungal or weevil damage, were cultured on PDA to isolate any fungi, that were associated with them.

Because discoloration was evident in both controls during the first inoculation, a second inoculation was conducted. In the first inoculation, no acorns were sterilized and treatment needles were not flamed, while the second inoculation trial included sterilization of acorns and needles. Sterilization consisted of wiping the surface of the acorns with $70 \%$ ethanol prior to inoculation. During the second inoculation trial, the hypodermic needle was flamed after each inoculation.

\section{Statistical Analysis}

At the end of each sample period (10, 20 and 30 days), the percent cotyledon discoloration was averaged for each treatment inoculum. The overall percent germination for all acorns also was calculated and broken down by time and treatment inocula. The frequency with which fungi were isolated from all acorns with or without discolored cotyledons, from all treatment inocula and time period also was determined. Analysis of variance (ANOVA) was conducted to examine the interaction between average percent discoloration and the three main effects; inoculation trial, treatment inocula, and time. ANOVA also was used to determine if there was a significant interaction between germination rates and the two inoculation trails. The alpha-level for all statistical analyses was set at 0.05 .

\section{RESULTS}

Following both inoculation trials, cotyledon discoloration was evident in almost all acorns, even when they were inoculated with tween 20 water or Cordyceps militaris. During the two inoculation trials, only two acorns that had no discoloration associated with their cotyledons, which occurred in the first inoculation trial. One was evident in the 10-day culturing and the other in the 20-day. 


\section{Visual assessment of cotyledon discoloration}

A significant difference $(\mathrm{p}<0.0001)$ was detected between the two inoculation trials with regard to the amount of cotyledon discoloration. This significance was seen because the level of discoloration for the second inoculation was $22 \%$ higher than that of the first, among all treatments. The average amount of discoloration seen in the first trial was $48 \%$, compared to $70 \%$ with the second trial (Table 3.1).

The particular fungus used for inoculations also was significant $(\mathrm{p}<0.0001)$ with regard to the level discoloration. The two treatments with the highest average cotyledon discoloration for the first inoculation trial were Penicillium terrestre (62\% discoloration) and the combination of all five fungi (61\%) (Table 3.1). The lowest overall percent of discoloration for the first trial was seen with tween 20 water and Penicillium chermesinum, 38\% and 35\% respectively (Table 3.1). The same two treatments that were associated with the highest average discoloration in the first trial also were highest for the second inoculation trial; Penicillium terrestre (82\%) and the combination of all five fungi (83\%). However, the lowest amount of discoloration for the second trial was seen with the Penicillium chermesinum and Rhizopus sp. 1 treatments, 57\% and 58\% respectively (Table 3.1). This amount of discoloration was almost as high as the maximum level seen at the end of the first trial.

Time also played a significant role $(\mathrm{p}=0.0129)$ in the amount of the cotyledon that was discolored in the second inoculation trial. In the first inoculation, there was little difference in the overall amount of discoloration among the three periods (Table 3.1). During the second inoculation discoloration averaged 59\% after the 10-day period and progressed from $73 \%$ to $76 \%$ discoloration with the 20-day and 30-day period (Table 3.1). As may be expected, there was a significant two-way interaction between inoculation trial and time $(\mathrm{p}=0.0375)$ with regard to discoloration of the cotyledon, since the second inoculation trial showed a significant increase in discoloration over time compared to the first trial (Table 3.1).

Another significant two-way interaction also was seen between fungal inocula and time period $(\mathrm{p}=0.0072)$ with regard to discoloration. During the first inoculation, Penicillium terrestre, Trichoderma, Fusarium, and Cordyceps militaris treatments all had increasing amount of 
discoloration from 10 to 20 days (Figure 3.2). Of these, only Fusarium continued to have an increase in the amount of discoloration from 20 to 30 days (Figure 3.2). The other four treatments, Penicillium chermesinum, Rhizopus 1, combined fungi and tween 20 water had a decrease in percent discoloration from 10 to 20 days (Figure 3.2). During the second inoculation, discoloration increased from 10 to 20 days in all treatments with two exceptions, Rhizopus 1 and Cordyceps militaris (Figure 3.3). These two treatments, however, did have increased amounts of discoloration from 20 to 30 days. A continual increase in discoloration was only seen with Fusarium and tween 20 water during the 10 to 30 day time period (Figure $3.3)$.

Fungi Isolated from Cotyledons

\section{First Inoculation Trial}

While some fungi were reisolated more successfully than others, all fungi used as treatment inocula were routinely reisolated, except Cordyceps militaris. This was especially true with regard to Penicillium chermesinum and Penicillium terretre (Table 3.3). Both were successfully reisolated from 100 percent of the acorns that were inoculated with these isolates, during all three time periods. In some instances, fungi were recovered from less than 100 percent of inoculated acorns especially as time progressed. This occurred when Rhizopus sp. 1 and Fusarium were used as inoculum. When the acorns that were inoculated with Trichoderma were cultured, more acorns had this fungus associated with them during the 30-day examination than during the 10day (Table 3.3). The combination of all five fungi showed no trend as to how often the fungi were recovered. However, all fungi used as inocula were reisolated, with the exception of Fusarium (Table 3.3).

Fungi, other than those used for inoculation, often were recovered from acorns. This was particularly true in acorns inoculated with Rhizopus sp. 1, Trichoderma sp. and Fusarium sp. (Table 3.3). In the two controls, tween 20 water and $C$. militaris, fungi were routinely cultured from the inoculated acorns. These fungi included Penicillium chermesinum and Penicillium terretreI, Pestalotia sp. and Rhizopus sp. 2 for the tween 20 water treatment (Table 3.3). With regard to the C. militaris inoculation, Penicillium chermesinum and Penicillium terretre, and Pestalotia sp. were isolated most frequently (Table 3.3). 


\section{Second Inoculation Trial}

As in first inoculation trial, all fungi used as inoculum for the second inoculation trial were reisolated except Cordyceps militaris. Some fungi were reisolated at a greater frequency than others were. Penicillium chermesinum and Penicillium terretre were successfully reisolated from 100 percent of all acorns from the corresponding treatments during all periods $(10,20$ and 30 days) (Table 3.4). Conversely, the amount of acorns that Trichoderma sp. was reisolated from decreased from 10 to 30 days after their inoculation, (Table 3.4). Fusarium sp. was successfully reisolated from $60 \%$ of the acorns in all time periods (Table 3.4). An increase in the amount of acorns that Rhizopus sp. 1 was reisolated from was seen only between the 10 and 20 day time periods (Table 3.4). The combination of all five fungi showed no time trend, but all fungi used as inocula were reisolated except Fusarium sp. (Figure 3.3).

Fungi, other than those used for inocula in this second inoculation trial, often were recovered from acorns. This was particularly true in acorns inoculated with Rhizopus sp. 1, Trichoderma sp. and Fusarium sp. (Table 3.4). In the two controls, tween 20 water and C. militaris, fungi were often cultured from the inoculated acorns. These fungi included Penicillium chermesinum and terrestre, and Pestalotia sp. for the detergent water inoculation (Table 3.4). With regard to the C. militaris inoculated acorns, Penicillium chermesinum and Penicillium terretre were most frequently isolated (Table 3.4).

\section{Apparently Sound Acorns}

Of the 50 acorns that sank during the float test, only three had discolored cotyledons. The average percent cotyledon discoloration for these 50 acorns was $3 \%$. However, all of the acorns that floated had either cotyledons that were completely discolored or had weevil damage. Cotyledons from the 50 acorns that sank were cultured, regardless of the cotyledon condition. All cotyledons, whether discolored or totally white, yielded fungi when cultured. The most commonly isolated fungus was Penicillium terrestre, 68\% (Figure 3.4).

\section{Germination Rate}

Some of the acorns germinated during the culturing trial, especially those in the first inoculation trial. Germination rate was significantly different $(\mathrm{p}<0.0001)$ between the two inoculation trials. 
The germination rate for the second inoculation was only $1 \%$. However, the first inoculation trial had an overall average germination rate of $16 \%$ (Table 3.2).

There were no significant two-way interactions with regard to germination, but there was one significant three-way interaction between inoculation trial, treatment inocula and time ( $\mathrm{p}<0.0001)$. Germination rates for the 30-day inoculated acorns were highest with Rhizopus 1, Penicillium chermesinum, and Fusarium inoculations during the first inoculation trial (Table 3.2). The lowest germination rate was associated with Penicillium terretre inoculations (3\%) during the first inoculation trial (Table 3.2). The amount of discoloration was associated with the amount of acorns that germinated during the second inoculation trial (Table 3.2). Germination rates during this trial among all time periods were very low.

\section{DISCUSSION AND CONCLUSION}

The field experiment (Chapter 2) clearly demonstrated that acorns are contaminated with a variety of fungi at some point in their development. Yet the experiment did not define their role as factors in acorn viability and germination. In this chapter an effort was made to evaluate the ability of the most commonly isolated fungi to colonize what were apparently sound (acorns with out discolored cotyledons) acorns. The eight different treatment inocula were: Penicillium chermesinum, Penicillium terrestre, Trichoderma sp., Rhizopus sp. 1, Fusarium sp., a combination of all five fungi, a tween 20 distilled water solution, and Cordyceps militaris, a nonpathogen of oak.

\section{Visual assessment of cotyledon discoloration}

During the first inoculation, acorns treated with the two control inocula, tween 20 water and Cordyceps militaris, a pathogen of insects, were not expected to have cotyledon discoloration, but that was not the case. These controls were utilized to compare the differences among them and the other treatments with fungi previously isolated. Considerable discoloration was evident in these treatments. The tween 20 water solution treatment had an average percent cotyledon discoloration of $38 \%$ and Cordyceps militaris an average of $42 \%$ in the first inoculation trial (Table 3.1). Most of the discoloration seemed to radiate from the injection site. Lack of acorn and needle sterilization may have led to contaminating fungi being introduced via the injection. 
However, this unlikely because the previous field experiment and the culturing of 50 acorns that had apparently healthy cotyledons showed that fungi are present in and on acorns regardless of their internal cotyledon condition.

The second inoculation was conducted, using sterile techniques. For the second inoculation trail, all acorns were surface sterilized with $70 \%$ ethanol and all treatment needles were flamed.

Despite this effort, there was still discoloration associated with acorn cotyledons that received the two control treatments. The tween 20 water solution treatment had an average percent cotyledon discoloration of $64 \%$ while Cordyceps militaris had an average of $72 \%$ (Table 3.1), even larger amounts than the first inoculation.

The discoloration of cotyledons in control treatments was discouraging. Even after the adoption of more sterile experimental conditions that were initiated in the second inoculation trial, substantial discoloration occurred in control acorns. A possible conclusion is that the contaminating fungi may be entering through the style channels around the edges of the hilum, located at the top of the acorn where the cap was connected (Winston 1956). This area is much softer than the rest of the acorn, thus allowing for easier fungal entry. If fungi entered in this way, then they must have been present within the shell and withstood the alcohol treatment. The fungi could then have entered via the vascular tissues.

Another explanation may be that fungi were inadvertently introduced via inoculation. The fungi deep within the shell may have also been forced into the cotyledon when inoculation took place. The needle also could have provided an entry court for fungi. As the needle pushed into the acorn, so did part of the hilum. If any hyphae or spores were present on this part of the acorn, they could have been easily introduced this way. Possibly the sterilization procedure using $70 \%$ ethanol was not sufficient. Maybe the acorns needed total submersion for a several minutes to effectively kill fungi on the surface of the acorn.

These data raise the possibility that fungi might be a natural part of oak acorns during the course of their development. The fungi that were chosen as treatment inocula may have been saprophytes that are more aggressive and out competed the other naturally occurring fungi in the 
acorns. However, other fungi, not just treatment inocula, were cultured from acorns in all treatments (Tables 3.3 and 3.4). This may indicate that fungi are inherently present in the cotyledon at all times. This rationale was further validated when the cotyledons of the 50 acorns that sank during the float test were cultured. Fungi were found in association with all of these acorns even when discoloration of the cotyledon was not present (Figure 3.4). Also, during the previous field experiment (Chapter 2), practically all acorns cultured, regardless of internal cotyledon condition had fungi associated with them when cultured. Therefore, these fungi may very well have been present on or inside the acorns before inoculation occurred as a nature part of the acorns microflora.

Some fungal inocula produced higher levels of discoloration than others $(\mathrm{p}<0.0001)$. This was seen during both inoculations. The two treatments with the highest average cotyledon discoloration for both inoculation trials were Penicillium terretre and the combination of all five fungi (Table 3.1). This result was probably expected because at every site and time of year in the previous experiment (Chapter 2), Penicillium terretre was the fungus seen most frequently with discolored or weevil damaged acorns. Penicillium terretre is an extremely abundant fungus in the ecosystem, which indicates that it may be more aggressive and competitive than other naturally occurring fungi like other species of Penicillium and Rhizopus as well as Pestalotia.

Inoculation trial also was significant $(\mathrm{p}<0.0001)$ with regard to the proportion of the cotyledon that was discolored. This was significant because the level of discoloration for the second inoculation was higher than that of first among all treatments, 22\% higher (Table 3.1). This result was unexpected since in the second inoculation I used techniques that are more sterile. Logically, these acorns should have had less discoloration, especially in the controls. This outcome could relate to factors such as differing environmental conditions of the two tests (although they were supposed to be similar and the start of second inoculation occurred only two weeks after the first). Perhaps the aging process during storage predisposed them to higher amount of discoloration with time. Unfortunately, this study is unable to answer the question and any proposed explanation is simply speculation. 
As expected, the level of discoloration increased over the course of the study with regard to when acorns were removed for examination and culturing, e.g., the 30-day acorns would have more discoloration than the 10-day acorns. However, data did not always support this explanation. The Fusarium treatment was the only one that showed a consistent increase over all periods, while the Rhizopus treatment had the only continual decrease (Figure 3.2). During the second inoculation, the Fusarium and tween 20 water treatments both showed a continual increase over all periods, while the other treatment showed no trends (Figure 3.3). This result was counter to that obtained in the previous field experiment (Chapter 2) where levels of discoloration increased over time at every site. In some cases, the levels actually decreased during this inoculation experiment. One explanation is that removing these acorns at 10-day intervals did not allow sufficient time for differences to occur. An alternative explanation is that the discoloration progresses very rapidly early on and then tapers off; therefore, the 10-day examination would capture the major effect.

\section{Fungi Isolated from Cotyledons}

Fungi that did not resemble the inocula, were cultured from acorns from all eight treatments in both inoculations (Tables 3.3, 3.4). Nevertheless, it was anticipated that the five fungi that were used as inocula would be subcultured; this was the case, with one exception. In the Fusarium treatment and the combination of all five fungi treatment, Fusarium was isolated infrequently (Tables 3.3,3.4). Penicillium chermesinum and Penicillium terretre seemed to be natural inhabitants of these acorns and might have out competed Fusarium. This is the most likely senario since Penicillium chermesinum and Penicillium terretre were among the fungi that were isolated from both the tween 20 water and Cordyceps militaris controls most frequently. However, the Fusarium inoculation only consisted of pieces of hyphae and this could explain why it was not recovered as frequently. At any rate, these fungi are most likely naturally occurring in acorns. These five species of fungi used as inoculum are complex and need to be examined with regard to their general habits.

Penicillium is a large and complex genus with a worldwide distribution. It is one of the most abundant genera of fungi in soils. Penicillium is an air-borne Deuteromycete that is found in decaying vegetation and is often a problem in food spoilage. Some species produce toxins 
making food inedible or poisonous. However, other species of Penicillium are beneficial to humans, one being the source of the drug, penicillin, produced by Penicillium chrysogenum, a commonly occurring mold. Other species of Penicillium are used to ripen cheeses that are referred to as bleu cheeses (Alexopoulos et al. 1996).

Rhizopus is a fungal genus that also is extremely widespread. It is found in soil, decaying fruits and vegetables, animal feces, and old bread. While some Rhizopus species are simply contaminants, others occasionally cause serious (and often fatal) infections in humans (Alexopoulos et al. 1996). One species, Rhizopus arrhizus, has been associated with the disease referred to as zygomycosis (Ribes et al 2000).

Trichoderma is a ubiquitous fungus that is widely distributed in the soil as well as on plant material, decaying vegetation, and wood. Trichoderma species are strongly antagonistic to other fungi, suggesting that they are microbial predators. This behavior has led to their use as biological control agents for some plant pathogenic fungi, in particular soil borne pathogens. However, they can be serious pests in cultivated mushroom beds (Alexopoulos et al. 1996).

Commonly found in soil, Fusarium is a widely distributed fungus. Some species are plant pathogens causing root and stem rots, vascular wilts or fruit rots. Other species cause storage rot and are important mycotoxin producers. Several species of Fusarium, are recognized as being pathogenic to humans and other animals (Alexopoulos et al. 1996).

Because these fungi are so common in the environment, they are most likely a part of an acorns microflora. Validation for this concept was produced when 50 acorns that sank during the float test were examined and cultured. The fungi that were cultured from these acorns were identical to the fungi that were cultured from the two controls during this experiment. The only logical explanation is that some fungi are consistently present in or on acorns.

While we known that fungi are associated with northern red oak acorns, it is still not certain where or when these fungi are acquired, but even though their cotyledons appear to be "healthy" when the test was conducted; they were colonized to some extent. This was evident when the 
controls and the 50 acorns that sank during the float test were cultured. This experiment was actually introducing fungi to already contaminated acorns. Therefore, this experiment could have very well changed the natural chain of events because of the physical damage of inoculation.

\section{Germination Rate}

Germination of acorns was expected to occur after 30 days, regardless of treatment. Some acorns did begin to germinate in the 10 and 20-day samples, however this was unusual. During the first inoculation trial, after 20 days, all treatments had some germination except those inoculated with Penicillium terrestre and Trichoderma sp. This seems consistent because Penicillium terrestre had the highest average percent discoloration during this time (70\%) (Table 3.2). The high level of discoloration may have resulted in the embryo being damaged to the extent that germination did not occur. After 30 days, the germination rates had not increased substantially. This could be due to longer exposure of the cotyledon to the fungal organisms thus causing more discoloration, further impacting germination. Therefore, levels of discoloration were apparently correlated with germination. Looking at the overall amount of discoloration and the overall germination rate by treatment, a specific trend can be seen. Treatments with levels of discoloration between $30 \%$ and $60 \%$, had germination rates of $10 \%$ to $25 \%$. However, once levels of cotyledon discoloration increased beyond $60 \%$, germination was non-existent.

The association between discoloration and germination is of great significance with regard to the results of this study and the process of northern red oak regeneration. These inoculation experiments demonstrated that high levels of discoloration of the cotyledon reduce germination. Data indicate that fungi entering and causing discoloration before the acorn has germinated reduces the germination rate. If the fungi do not cause a substantial amount of discoloration, this cotyledon remains sufficiently healthy to germinate.

Another interesting finding was that germination rates between the two inoculation trials were significantly different $(\mathrm{p}<0.0001)$. The second inoculation had virtually no germination. This may be partially explained by Vozzo (1984) who stated that seeds, in particular acorns, do not germinate once surface sterilized. This could be because the presence of fungi aids in 
germination by softening the pericarp thus allowing the shell to break open more easily. This explanation for the lack of germination by acorns during the second inoculation is quite interesting. The fact that fungi may be beneficial to an acorn brings up the idea of a mutual relationship. The fungi may soften the shell to help the acorn germinate and in return the fungi can then begin to break down the rest of the acorn, including the cotyledon once germination has occurred.

Another explanation for the lack of germination during the second inoculation trial is that the embryo of the acorns was killed because of the alcohol sterilization. This could be true, however, the amount of alcohol the may have entered the acorns by just wiping their surface with alcohol may have been so small that there was little or no effect on germination. Whatever the cause, a reduction in germination during the second inoculation was evident.

In chapter 2, many June-harvested acorns had significant discoloration associated with their cotyledons, however they germinated and produced healthy seedlings. However, the Marchharvested acorns, which were just beginning to germinate, were not geminated when high levels of cotyledon discoloration were present. These two experiments prove that germination will occur if high levels of discoloration do not occur prior to the seed coat breaking open. However, fungi may apparently be beneficial to help soften the seed coat so that germination can take place. 
Table 3.1. Visual assessment of the average amount of cotyledon discolored for first and second inoculation by time.

\begin{tabular}{|c|c|c|c|c|c|c|c|c|c|c|}
\hline \multicolumn{11}{|c|}{ Average Amount of Cotyledon Discolored for First and Second Inoculation by Time } \\
\hline & & Penicillium 1 & Penicillium 2 & Rhizopus 1 & Trichoderma & Fusarium & All & Water & Cordyceps & Overall Average * \\
\hline \multirow{4}{*}{$\begin{array}{c}1^{\text {st }} \\
\text { Inoculation }\end{array}$} & 10-Days & $47 \%$ & $53 \%$ & $61 \%$ & $34 \%$ & $39 \%$ & $62 \%$ & $47 \%$ & $36 \%$ & $47 \%^{\mathrm{a}}$ \\
\hline & 20-Days & $27 \%$ & $70 \%$ & $58 \%$ & $58 \%$ & $59 \%$ & $61 \%$ & $27 \%$ & $46 \%$ & $51 \%^{a}$ \\
\hline & 30-Days & $32 \%$ & $62 \%$ & $20 \%$ & $51 \%$ & $69 \%$ & $61 \%$ & $40 \%$ & $44 \%$ & $47 \%^{a}$ \\
\hline & Overall * & $35 \%^{a}$ & $62 \%^{b}$ & $46 \%^{a}$ & $48 \%^{a}$ & $55 \%$ ab & $61 \%^{b}$ & $38 \%^{a}$ & $42 \%^{a}$ & $48 \%$ \\
\hline \multirow{4}{*}{$\begin{array}{c}2^{\text {nd }} \\
\text { Inoculation }\end{array}$} & 10-Days & $51 \%$ & $59 \%$ & $68 \%$ & $58 \%$ & $46 \%$ & $65 \%$ & $40 \%$ & $83 \%$ & $59 \%^{a}$ \\
\hline & 20-Days & $62 \%$ & $94 \%$ & $43 \%$ & $72 \%$ & $87 \%$ & $92 \%$ & $73 \%$ & $64 \%$ & $73 \%^{b}$ \\
\hline & 30-Days & $61 \%$ & $93 \%$ & $60 \%$ & $68 \%$ & $89 \%$ & $91 \%$ & $80 \%$ & $69 \%$ & $76 \%^{b}$ \\
\hline & Overall * & $58 \%^{a}$ & $82 \%^{b}$ & $57 \%^{a}$ & $66 \%{ }^{a b}$ & $74 \%{ }^{b}$ & $83 \%^{b}$ & $64 \%^{a}$ & $72 \%{ }^{b}$ & $70 \%$ \\
\hline
\end{tabular}

*Letters represent significant difference at the $\mathrm{p}<0.0001$.

Table 3.2. Germination rates for first and second inoculations.

\begin{tabular}{|c|c|c|c|c|c|c|c|c|c|c|}
\hline & & \multicolumn{9}{|c|}{ Germination Rates for First and Second Inoculations by Time } \\
\hline & & Penicillium 1 & Penicillium 2 & Rhizopus 1 & Trichoderma & Fusarium & All & Water & Cordyceps & Overall Percentage \\
\hline \multirow{4}{*}{$\begin{array}{c}1^{\text {st }} \\
\text { Inoculation }\end{array}$} & 10-Days & $10 \%$ & $0 \%$ & $0 \%$ & $0 \%$ & $0 \%$ & $0 \%$ & $0 \%$ & $0 \%$ & $1 \%$ \\
\hline & 20-Days & $40 \%$ & $0 \%$ & $40 \%$ & $0 \%$ & $30 \%$ & $10 \%$ & $20 \%$ & $30 \%$ & $21 \%$ \\
\hline & 30-Days & $10 \%$ & $10 \%$ & $30 \%$ & $40 \%$ & $30 \%$ & $20 \%$ & $30 \%$ & $30 \%$ & $25 \%$ \\
\hline & Overall & $20 \%$ & $3 \%$ & $23 \%$ & $13 \%$ & $20 \%$ & $10 \%$ & $17 \%$ & $20 \%$ & $16 \%$ \\
\hline \multirow{4}{*}{$\begin{array}{c}2^{\text {nd }} \\
\text { Inoculation }\end{array}$} & 10-Days & $0 \%$ & $0 \%$ & $0 \%$ & $0 \%$ & $0 \%$ & $0 \%$ & $0 \%$ & $0 \%$ & $0 \%$ \\
\hline & 20-Days & $0 \%$ & $0 \%$ & $0 \%$ & $0 \%$ & $0 \%$ & $0 \%$ & $0 \%$ & $0 \%$ & $0 \%$ \\
\hline & 30-Days & $0 \%$ & $0 \%$ & $0 \%$ & $10 \%$ & $0 \%$ & $0 \%$ & $0 \%$ & $10 \%$ & $3 \%$ \\
\hline & Overall & $0 \%$ & $0 \%$ & $0 \%$ & $3 \%$ & $0 \%$ & $0 \%$ & $0 \%$ & $3 \%$ & $1 \%$ \\
\hline
\end{tabular}


Table 3.3. Frequency of fungi isolated from first inoculation.

\begin{tabular}{|l|c|c|c|c|c|c|c|c|c|c|}
\hline \multicolumn{7}{|c|}{ Frequency of Fungi Isolated from First Inoculation } \\
\hline $\begin{array}{c}\text { Fungal } \\
\text { Inoculum }\end{array}$ & $\begin{array}{c}\text { Penicillium } \\
\mathbf{1}\end{array}$ & $\begin{array}{c}\text { Penicillium } \\
\mathbf{2}\end{array}$ & $\begin{array}{c}\text { Rhizopus } \\
\mathbf{1}\end{array}$ & Trichoderma & Fusarium & $\begin{array}{c}\text { Rhizopus } \\
\mathbf{2}\end{array}$ & Pestalotia & $\begin{array}{c}\text { Penicillium } \\
\mathbf{3}\end{array}$ & $\mathbf{7}$ & $\mathbf{2 0 5}$ \\
\hline Penicillium 1 & $100 \%$ & $7 \%$ & $0 \%$ & $0 \%$ & $3 \%$ & $0 \%$ & $10 \%$ & $0 \%$ & $3 \%$ & $3 \%$ \\
\hline Penicillium 2 & $3 \%$ & $100 \%$ & $0 \%$ & $10 \%$ & $0 \%$ & $3 \%$ & $3 \%$ & $0 \%$ & $0 \%$ & $3 \%$ \\
\hline Rhizopus 1 & $37 \%$ & $10 \%$ & $60 \%$ & $0 \%$ & $7 \%$ & $0 \%$ & $10 \%$ & $0 \%$ & $73 \%$ & $0 \%$ \\
\hline Trichoderma & $43 \%$ & $0 \%$ & $17 \%$ & $77 \%$ & $3 \%$ & $0 \%$ & $27 \%$ & $0 \%$ & $10 \%$ & $17 \%$ \\
\hline Fusarium & $87 \%$ & $0 \%$ & $3 \%$ & $0 \%$ & $23 \%$ & $13 \%$ & $0 \%$ & $0 \%$ & $7 \%$ & $3 \%$ \\
\hline All & $60 \%$ & $93 \%$ & $63 \%$ & $30 \%$ & $0 \%$ & $3 \%$ & $3 \%$ & $0 \%$ & $27 \%$ & $3 \%$ \\
\hline Water & $70 \%$ & $33 \%$ & $0 \%$ & $0 \%$ & $10 \%$ & $20 \%$ & $50 \%$ & $10 \%$ & $0 \%$ & $0 \%$ \\
\hline Cordyceps & $53 \%$ & $33 \%$ & $0 \%$ & $0 \%$ & $7 \%$ & $7 \%$ & $7 \%$ & $10 \%$ & $0 \%$ & $0 \%$ \\
\hline
\end{tabular}

Table 3.4. Frequency of fungi isolated from second inoculation.

\begin{tabular}{|c|c|c|c|c|c|c|c|c|c|c|c|}
\hline \multicolumn{12}{|c|}{ Frequency of Fungi Isolated from Second Inoculation } \\
\hline $\begin{array}{c}\text { Fungal } \\
\text { Inoculum }\end{array}$ & $\begin{array}{c}\text { Penicillium } \\
1\end{array}$ & $\underset{2}{\text { Penicillium }}$ & $\begin{array}{c}\text { Rhizopus } \\
1\end{array}$ & Trichoderma & Fusarium & \begin{tabular}{|c|} 
Rhizopus \\
2
\end{tabular} & Pestalotia & \begin{tabular}{|c} 
Penicillium \\
$\mathbf{3}$ \\
\end{tabular} & \begin{tabular}{|c} 
Penicillium \\
4
\end{tabular} & 7 & 207 \\
\hline Penicillium 1 & $100 \%$ & $0 \%$ & $0 \%$ & $0 \%$ & $0 \%$ & $7 \%$ & $0 \%$ & $0 \%$ & $0 \%$ & $0 \%$ & $0 \%$ \\
\hline Penicillium 2 & $0 \%$ & $100 \%$ & $0 \%$ & $0 \%$ & $3 \%$ & $7 \%$ & $0 \%$ & $0 \%$ & $3 \%$ & $3 \%$ & $0 \%$ \\
\hline Rhizopus 1 & $53 \%$ & $13 \%$ & $83 \%$ & $7 \%$ & $7 \%$ & $3 \%$ & $13 \%$ & $0 \%$ & $0 \%$ & $23 \%$ & $7 \%$ \\
\hline Trichoderma & $20 \%$ & $13 \%$ & $0 \%$ & $97 \%$ & $0 \%$ & $0 \%$ & $0 \%$ & $0 \%$ & $7 \%$ & $0 \%$ & $0 \%$ \\
\hline Fusarium & $87 \%$ & $37 \%$ & $17 \%$ & $0 \%$ & $60 \%$ & $0 \%$ & $10 \%$ & $17 \%$ & $0 \%$ & $7 \%$ & $10 \%$ \\
\hline All & $50 \%$ & $80 \%$ & $70 \%$ & $43 \%$ & $7 \%$ & $0 \%$ & $0 \%$ & $0 \%$ & $0 \%$ & $3 \%$ & $0 \%$ \\
\hline Water & $37 \%$ & $37 \%$ & $0 \%$ & $0 \%$ & $13 \%$ & $13 \%$ & $30 \%$ & $0 \%$ & $13 \%$ & $0 \%$ & $13 \%$ \\
\hline Cordyceps & $70 \%$ & $30 \%$ & $0 \%$ & $10 \%$ & $10 \%$ & $13 \%$ & $0 \%$ & $0 \%$ & $7 \%$ & $0 \%$ & $10 \%$ \\
\hline
\end{tabular}


Figure 3.1. Picture of tray containing 15 acorns

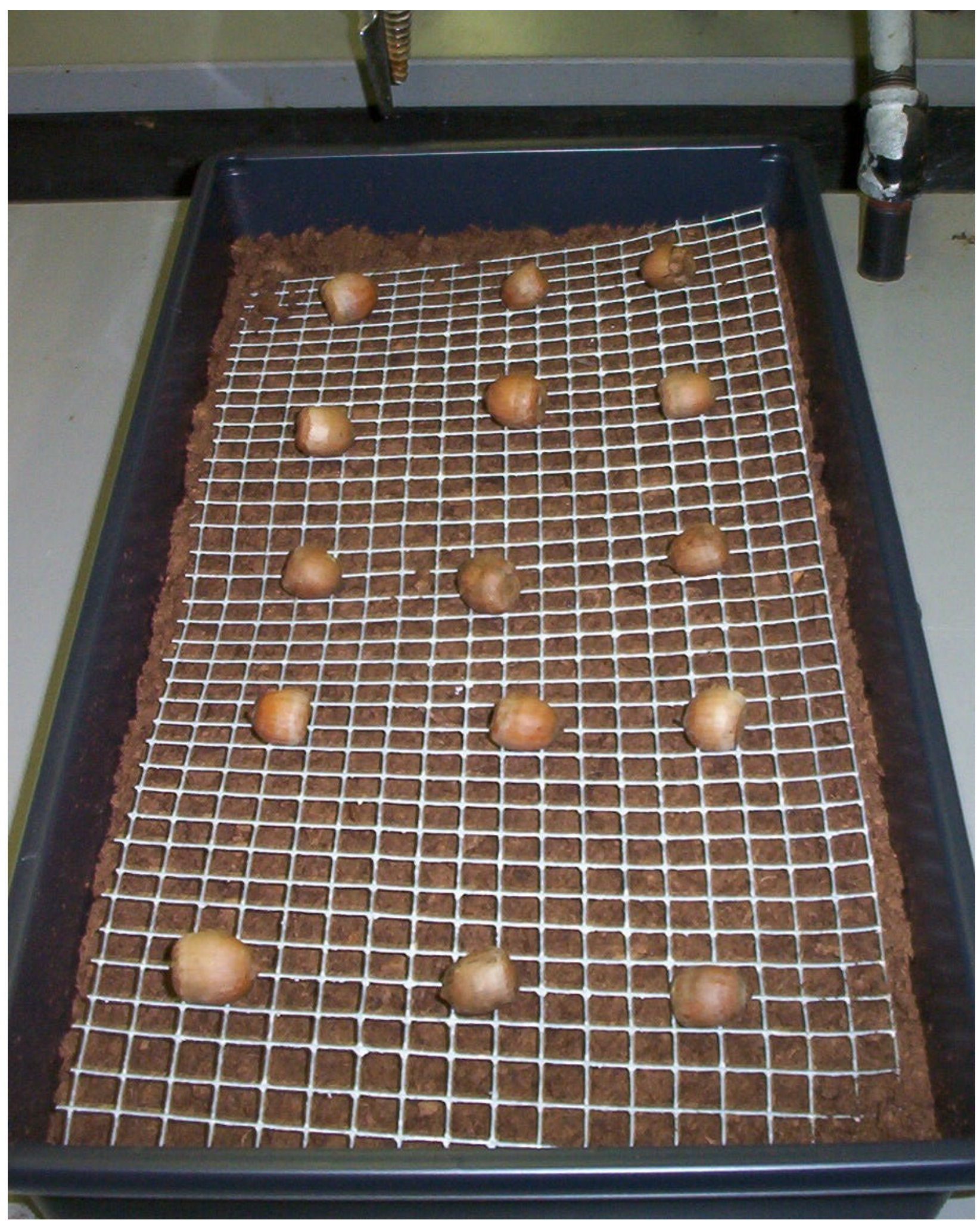


Figure 3.2: Average Percent Cotyledon Discoloration Over Time for First Inoculation

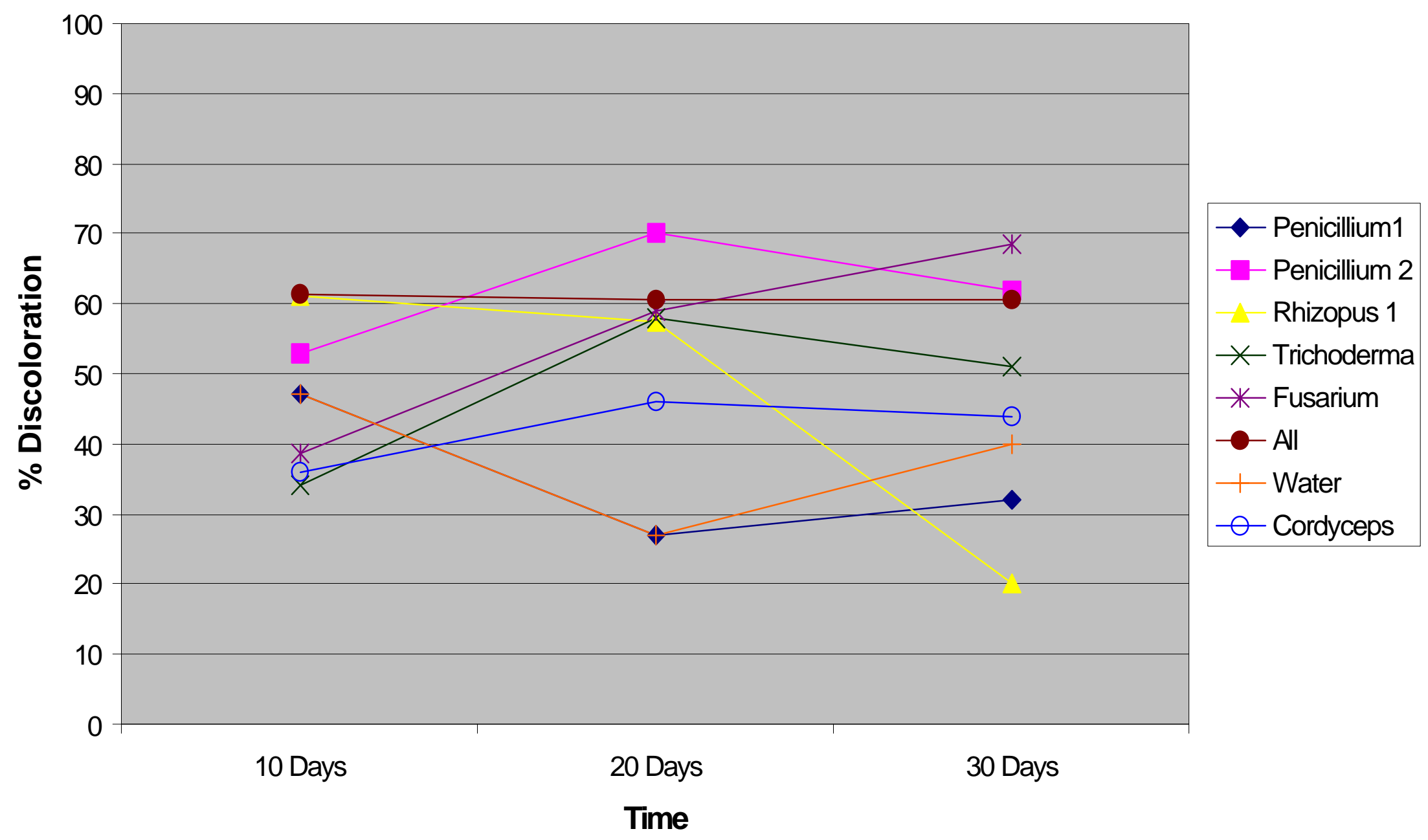


Figure 3.3: Average Percent Cotyledon Discoloration Over Time for Second Inoculation

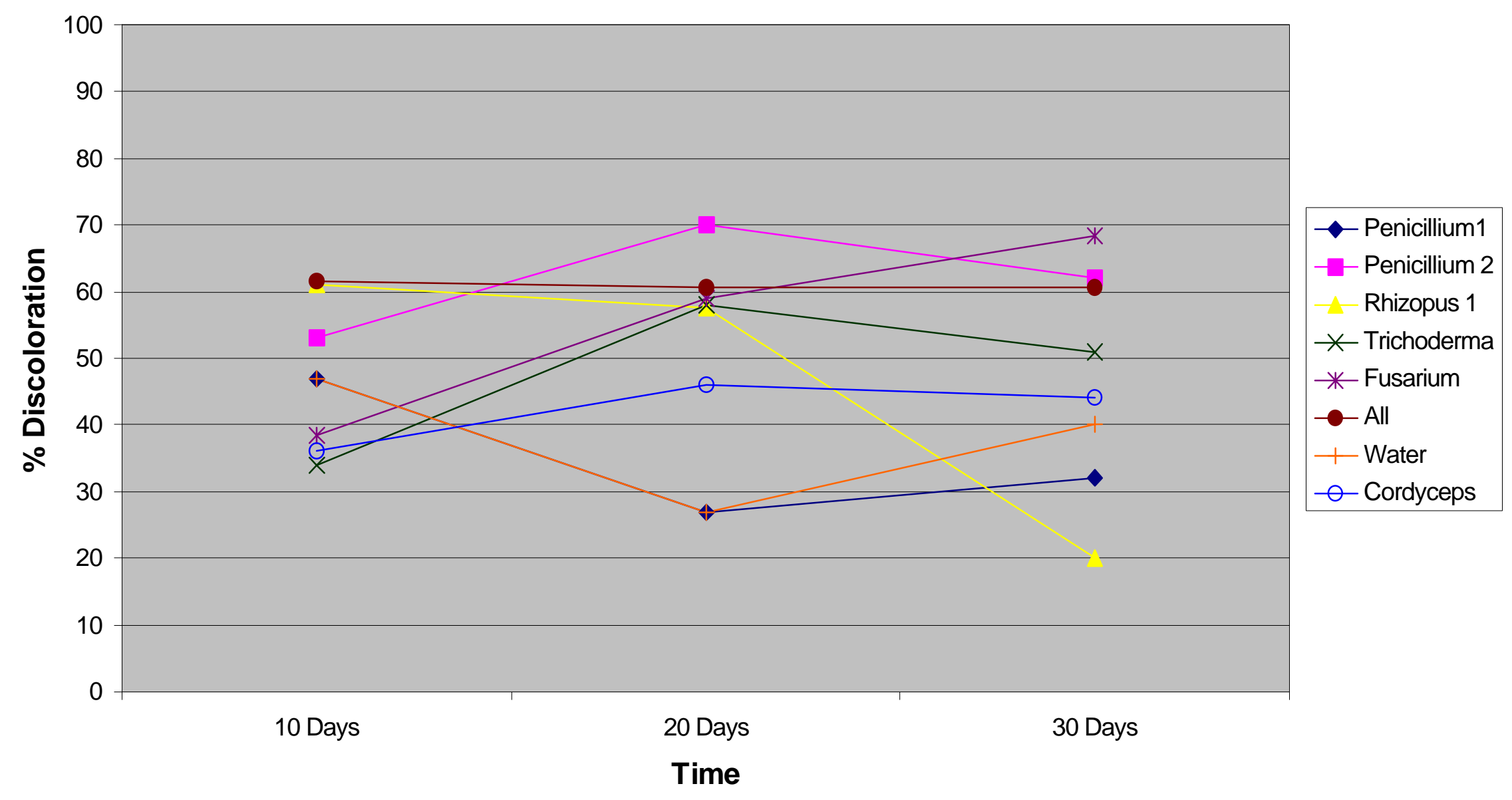


Figure 3.4: Frequency of Fungi Isolated from the Cotyledons of 50 Acorns that Sank During the Float Test

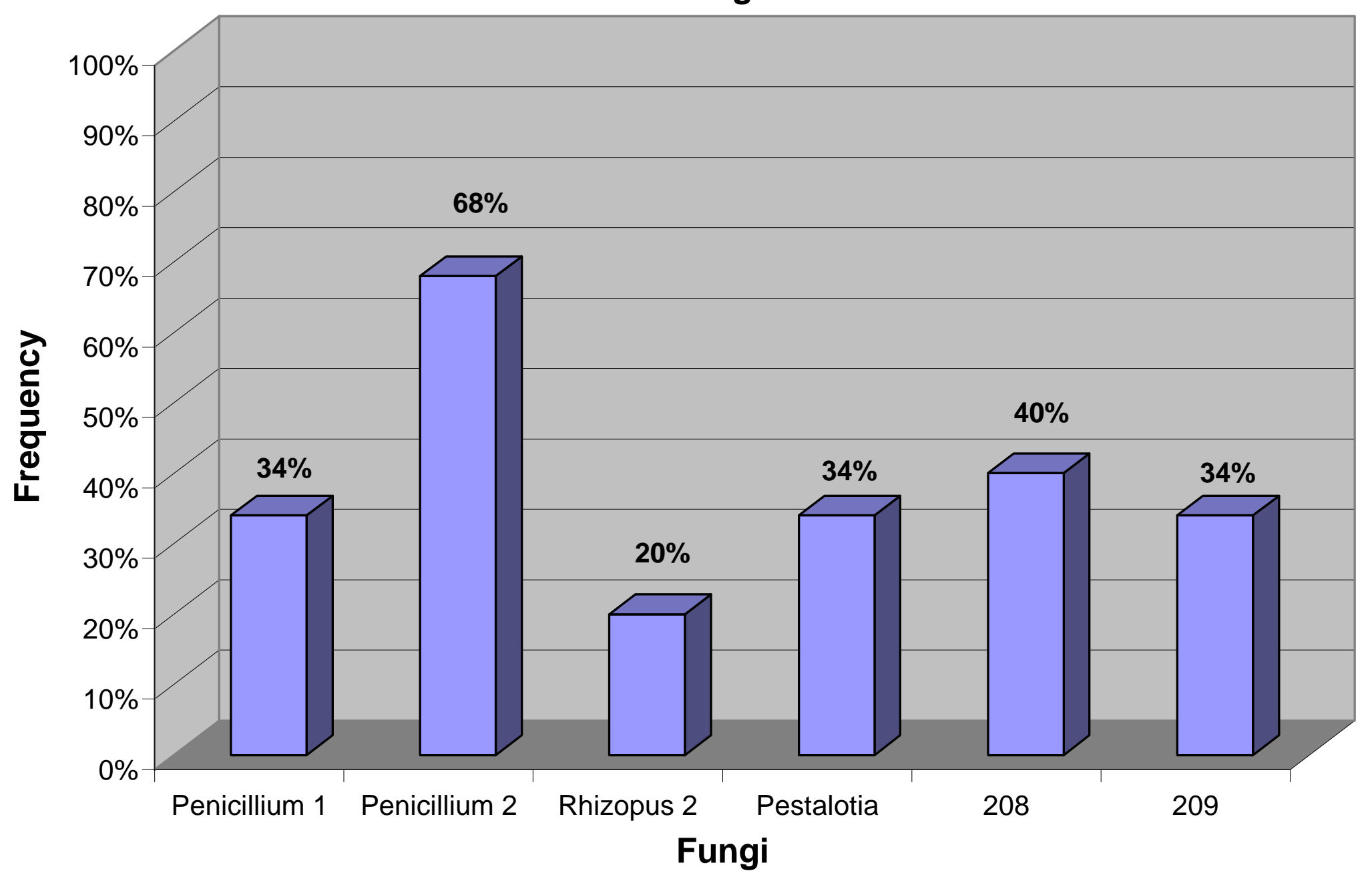




\section{LITERATURE CITED}

Alexopoulos, C.J., C.W. Mims, and M. Blackwell. 1996. Introductory Mycology, $4^{\text {th }}$ ed. John Wiley \& Sons, Inc. New York, New York.

Gribko, L.S. and W. E. Jones. 1995. Test of the float method of assessing northern red oak acorn viability. Tree Planter's Notes 46:143-147.

Ribes, J. A., C. L. Vanover-Sams, and D. J. Baker. 2000. Zygomycetes in human disease. Clinical Microbial Review 13:236-301.

Schopmeyer, C.S., tech. coord. 1974. Seeds of woody plants in the United States. USDA Forest Service Agricultural Handbook No. 450, 883 pp.

Vozzo, J.A. 1984. Insects and fungi associated with acorns of Quercus sp. USDA Forest Service General Technical Report S-40-43 p. Southern Forest Experimental Station, Starkville, Mississippi. 


\section{Appendix A \\ Tables: Number of Acorns by Harvest Date, Site, Treatment, and Condition.}


Table A.1. Number of December-harvested acorns that have discolored, discolored/weevil damaged and weevil damaged cotyledons by treatment and site.

\begin{tabular}{|l|c|c|c|c|c|c|c|c|c|c|c|c|c|}
\hline \multicolumn{10}{|c|}{ December-Harvested Acorns } \\
\hline Treatment & \multicolumn{4}{|c|}{ Discolored } & \multicolumn{1}{|c|}{ Discolored and Weevil } & \multicolumn{3}{c|}{ Weevil Damaged } \\
\hline & Laurel & Lick & Glade & Total & Laurel & Lick & Glade & Total & Laurel & Lick & Glade & Total \\
\hline Notched & 17 & 9 & 5 & $\mathbf{3 1}$ & 0 & 0 & 0 & $\mathbf{0}$ & 5 & 2 & 6 & $\mathbf{1 3}$ \\
\hline Sound & 3 & 4 & 5 & $\mathbf{1 2}$ & 0 & 0 & 0 & $\mathbf{0}$ & 7 & 9 & 4 & $\mathbf{2 0}$ \\
\hline Buried & 2 & 10 & 2 & $\mathbf{1 4}$ & 0 & 0 & 0 & $\mathbf{0}$ & 5 & 4 & 7 & $\mathbf{1 6}$ \\
\hline Surface & 18 & 3 & 8 & $\mathbf{2 9}$ & 0 & 0 & 0 & $\mathbf{0}$ & 7 & 7 & 3 & $\mathbf{1 7}$ \\
\hline Notched/Buried & 2 & 6 & 0 & $\mathbf{8}$ & 0 & 0 & 0 & $\mathbf{0}$ & 3 & 1 & 4 & $\mathbf{8}$ \\
\hline Sound/Buried & 0 & 4 & 2 & $\mathbf{6}$ & 0 & 0 & 0 & $\mathbf{0}$ & 2 & 3 & 3 & $\mathbf{8}$ \\
\hline Notched/Surface & 15 & 3 & 5 & $\mathbf{2 3}$ & 0 & 0 & 0 & $\mathbf{0}$ & 2 & 1 & 2 & $\mathbf{5}$ \\
\hline Sound/Surface & 3 & 0 & 3 & $\mathbf{6}$ & 0 & 0 & 0 & $\mathbf{0}$ & 5 & 6 & 1 & $\mathbf{1 2}$ \\
\hline Total & $\mathbf{2 0}$ & $\mathbf{1 3}$ & $\mathbf{1 0}$ & $\mathbf{4 3}$ & $\mathbf{0}$ & $\mathbf{0}$ & $\mathbf{0}$ & $\mathbf{0}$ & $\mathbf{1 2}$ & $\mathbf{1 1}$ & $\mathbf{1 0}$ & $\mathbf{3 3}$ \\
\hline
\end{tabular}

Table A.2. Number of March-harvested acorns that have discolored, discolored/weevil damaged and weevil damaged cotyledons by treatment and site.

\begin{tabular}{|l|c|c|c|c|c|c|c|c|c|c|c|c|c|}
\hline \multicolumn{10}{|c|}{ March-Harvested Acorns } \\
\hline Treatment & \multicolumn{9}{|c|}{ Discolored } & \multicolumn{1}{|c|}{ Discolored and Weevil } & \multicolumn{3}{c|}{ Weevil Damaged } \\
\hline & Laurel & Lick & Glade & Total & Laurel & Lick & Glade & Total & Laurel & Lick & Glade & Total \\
\hline Notched & 34 & 14 & 10 & $\mathbf{5 8}$ & 1 & 0 & 0 & $\mathbf{1}$ & 2 & 3 & 6 & $\mathbf{1 1}$ \\
\hline Sound & 8 & 11 & 4 & $\mathbf{2 3}$ & 0 & 0 & 1 & $\mathbf{1}$ & 5 & 1 & 7 & $\mathbf{1 3}$ \\
\hline Buried & 6 & 12 & 4 & $\mathbf{2 2}$ & 1 & 0 & 0 & $\mathbf{1}$ & 4 & 2 & 6 & $\mathbf{1 2}$ \\
\hline Surface & 36 & 13 & 10 & $\mathbf{5 9}$ & 0 & 0 & 1 & $\mathbf{1}$ & 3 & 2 & 7 & $\mathbf{1 2}$ \\
\hline Notched/Buried & 3 & 4 & 3 & $\mathbf{1 0}$ & 1 & 0 & 0 & $\mathbf{1}$ & 1 & 2 & 3 & $\mathbf{6}$ \\
\hline Sound/Buried & 3 & 8 & 1 & $\mathbf{1 2}$ & 0 & 0 & 0 & $\mathbf{0}$ & 3 & 0 & 3 & $\mathbf{6}$ \\
\hline Notched/Surface & 31 & 10 & 7 & $\mathbf{4 8}$ & 0 & 0 & 0 & $\mathbf{0}$ & 1 & 1 & 3 & $\mathbf{5}$ \\
\hline Sound/Surface & 5 & 3 & 3 & $\mathbf{1 1}$ & 0 & 0 & 1 & $\mathbf{1}$ & 2 & 1 & 4 & $\mathbf{7}$ \\
\hline Total & $\mathbf{4 2}$ & $\mathbf{2 5}$ & $\mathbf{1 4}$ & $\mathbf{8 1}$ & $\mathbf{1}$ & $\mathbf{0}$ & $\mathbf{1}$ & $\mathbf{2}$ & $\mathbf{7}$ & $\mathbf{4}$ & $\mathbf{1 3}$ & $\mathbf{2 4}$ \\
\hline
\end{tabular}

Table A.3. Number of June-harvested acorns that have discolored, discolored/weevil damaged and weevil damaged cotyledons by treatment and site.

\begin{tabular}{|l|c|c|c|c|c|c|c|c|c|c|c|c|c|}
\hline \multicolumn{10}{|c|}{ Dune-Harvested Acorns } \\
\hline Treatment & \multicolumn{9}{|c|}{ Discolored } & \multicolumn{10}{|c|}{ Discolored and Weevil } & \multicolumn{3}{c|}{ Weevil Damaged } \\
\hline & Laurel & Lick & Glade & Total & Laurel & Lick & Glade & Total & Laurel & Lick & Glade & Total \\
\hline Notched & 27 & 22 & 19 & $\mathbf{6 8}$ & 17 & 4 & 5 & $\mathbf{2 6}$ & 50 & 2 & 12 & $\mathbf{6 4}$ \\
\hline Sound & 21 & 29 & 13 & $\mathbf{6 3}$ & 13 & 4 & 5 & $\mathbf{2 2}$ & 42 & 6 & 17 & $\mathbf{6 5}$ \\
\hline Buried & 34 & 17 & 9 & $\mathbf{6 0}$ & 13 & 0 & 2 & $\mathbf{1 5}$ & 22 & 2 & 4 & $\mathbf{2 8}$ \\
\hline Surface & 14 & 34 & 23 & $\mathbf{7 1}$ & 17 & 8 & 8 & $\mathbf{3 3}$ & 70 & 6 & 25 & $\mathbf{1 0 1}$ \\
\hline Notched/Buried & 20 & 8 & 5 & $\mathbf{3 3}$ & 5 & 0 & 1 & $\mathbf{6}$ & 14 & 0 & 1 & $\mathbf{1 5}$ \\
\hline Sound/Buried & 14 & 9 & 4 & $\mathbf{2 7}$ & 8 & 0 & 1 & $\mathbf{9}$ & 8 & 2 & 3 & $\mathbf{1 3}$ \\
\hline Notched/Surface & 7 & 14 & 14 & $\mathbf{3 5}$ & 12 & 4 & 4 & $\mathbf{2 0}$ & 36 & 2 & 11 & $\mathbf{4 9}$ \\
\hline Sound/Surface & 7 & 20 & 9 & $\mathbf{3 6}$ & 5 & 4 & 4 & $\mathbf{1 3}$ & 34 & 4 & 14 & $\mathbf{5 2}$ \\
\hline Total & $\mathbf{4 8}$ & $\mathbf{5 1}$ & $\mathbf{3 2}$ & $\mathbf{1 3 1}$ & $\mathbf{3 0}$ & $\mathbf{8}$ & $\mathbf{1 0}$ & $\mathbf{4 8}$ & $\mathbf{9 2}$ & $\mathbf{8}$ & $\mathbf{2 9}$ & $\mathbf{1 2 9}$ \\
\hline
\end{tabular}


Table A.4. Number of acorns with discolored, discolored/weevil damaged and weevil damaged cotyledons by treatment, harvest date and site.

\begin{tabular}{|l|c|c|c|c|c|c|c|c|c|c|c|c|c|}
\hline \multicolumn{10}{|c|}{ Dumber of Acorns by Condition and Harvest Date } \\
\hline Treatment & \multicolumn{3}{|c|}{ Discolored } & \multicolumn{3}{c|}{ Discolored and Weevil } & \multicolumn{3}{c|}{ Weevil Damaged } \\
\hline & Dec. & Mar. & June & Total & Dec. & Mar. & June & Total & Dec. & Mar. & June & Total \\
\hline Notched & 31 & 58 & 68 & $\mathbf{1 5 7}$ & 0 & 1 & 26 & $\mathbf{2 7}$ & 13 & 11 & 64 & $\mathbf{8 8}$ \\
\hline Sound & 12 & 23 & 63 & $\mathbf{9 8}$ & 0 & 1 & 22 & $\mathbf{2 3}$ & 20 & 13 & 65 & $\mathbf{9 8}$ \\
\hline Buried & 14 & 22 & 60 & $\mathbf{9 6}$ & 0 & 1 & 15 & $\mathbf{1 6}$ & 16 & 12 & 28 & $\mathbf{5 6}$ \\
\hline Surface & 29 & 59 & 71 & $\mathbf{1 5 9}$ & 0 & 1 & 33 & $\mathbf{3 4}$ & 17 & 12 & 101 & $\mathbf{1 3 0}$ \\
\hline Notched/Buried & 8 & 10 & 33 & $\mathbf{5 1}$ & 0 & 1 & 6 & $\mathbf{7}$ & 8 & 6 & 15 & $\mathbf{2 9}$ \\
\hline Sound/Buried & 6 & 12 & 27 & $\mathbf{4 5}$ & 0 & 0 & 9 & $\mathbf{9}$ & 8 & 6 & 13 & $\mathbf{2 7}$ \\
\hline Notched/Surface & 23 & 48 & 35 & $\mathbf{1 0 6}$ & 0 & 0 & 20 & $\mathbf{2 0}$ & 5 & 5 & 49 & $\mathbf{5 9}$ \\
\hline Sound/Surface & 6 & 11 & 36 & $\mathbf{5 3}$ & 0 & 1 & 13 & $\mathbf{1 4}$ & 12 & 7 & 52 & $\mathbf{7 1}$ \\
\hline Total & $\mathbf{4 3}$ & $\mathbf{8 1}$ & $\mathbf{1 3 1}$ & $\mathbf{2 5 5}$ & $\mathbf{0}$ & $\mathbf{2}$ & $\mathbf{4 8}$ & $\mathbf{5 0}$ & $\mathbf{3 3}$ & $\mathbf{2 4}$ & $\mathbf{1 2 9}$ & $\mathbf{1 8 6}$ \\
\hline
\end{tabular}

Table A.5. Number of acorns with discoloration and weevil damaged cotyledons by treatment, harvest date and site.

\begin{tabular}{|l|c|c|c|c|c|c|c|c|c|c|c|c|}
\hline \multicolumn{10}{|c|}{ Discoloration and Weevil Damage Totals by Site and Harvest Date } \\
\hline Treatment & \multicolumn{4}{|c|}{ Glade } & \multicolumn{3}{c|}{ Lick } & \multicolumn{5}{c|}{ Laurel } \\
\hline & Dec. & Mar. June & Total & Dec. & Mar. & June & Total & Dec. & Mar. & June & Total \\
\hline Notched & 0 & 0 & 5 & $\mathbf{5}$ & 0 & 0 & 4 & $\mathbf{4}$ & 0 & 1 & 17 & $\mathbf{1 8}$ \\
\hline Sound & 0 & 1 & 5 & $\mathbf{6}$ & 0 & 0 & 4 & $\mathbf{4}$ & 0 & 0 & 13 & $\mathbf{1 3}$ \\
\hline Buried & 0 & 0 & 2 & $\mathbf{2}$ & 0 & 0 & 0 & $\mathbf{0}$ & 0 & 1 & 13 & $\mathbf{1 4}$ \\
\hline Surface & 0 & 1 & 8 & $\mathbf{9}$ & 0 & 0 & 8 & $\mathbf{8}$ & 0 & 0 & 17 & $\mathbf{1 7}$ \\
\hline Notched/Buried & 0 & 0 & 1 & $\mathbf{1}$ & 0 & 0 & 0 & $\mathbf{0}$ & 0 & 1 & 5 & $\mathbf{6}$ \\
\hline Sound/Buried & 0 & 0 & 1 & $\mathbf{1}$ & 0 & 0 & 0 & $\mathbf{0}$ & 0 & 0 & 8 & $\mathbf{8}$ \\
\hline Notched/Surface & 0 & 0 & 4 & $\mathbf{4}$ & 0 & 0 & 4 & $\mathbf{4}$ & 0 & 0 & 12 & $\mathbf{1 2}$ \\
\hline Sound/Surface & 0 & 1 & 4 & $\mathbf{5}$ & 0 & 0 & 4 & $\mathbf{4}$ & 0 & 0 & 5 & $\mathbf{5}$ \\
\hline Total & $\mathbf{0}$ & $\mathbf{1}$ & $\mathbf{1 0}$ & $\mathbf{1 1}$ & $\mathbf{0}$ & $\mathbf{0}$ & $\mathbf{8}$ & $\mathbf{8}$ & $\mathbf{0}$ & $\mathbf{1}$ & $\mathbf{3 0}$ & $\mathbf{3 1}$ \\
\hline
\end{tabular}

Table A.6. Number of weevil damaged acorns by treatment, harvest date and site.

\begin{tabular}{|c|c|c|c|c|c|c|c|c|c|c|c|c|}
\hline \multicolumn{13}{|c|}{ Weevil Damage Totals by Site and Harvest Date } \\
\hline Treatment & \multicolumn{4}{|c|}{ Glade } & \multicolumn{4}{|c|}{ Lick } & \multicolumn{4}{|c|}{ Laurel } \\
\hline & Dec. & Mar. & June & Total & Dec. & Mar. & June & Total & Dec. & Mar. & June & Total \\
\hline Notched & 6 & 6 & 12 & 24 & 2 & 3 & 2 & 7 & 5 & 2 & 50 & 57 \\
\hline Sound & 4 & 7 & 17 & 28 & 9 & 1 & 6 & 16 & 7 & 5 & 42 & 54 \\
\hline Buried & 7 & 6 & 4 & 17 & 4 & 2 & 2 & 8 & 5 & 4 & 22 & 31 \\
\hline Surface & 3 & 7 & 25 & 35 & 7 & 2 & 6 & 15 & 7 & 3 & 70 & 80 \\
\hline Notched/Buried & 4 & 3 & 1 & 8 & 1 & 2 & 0 & 3 & 3 & 1 & 14 & 18 \\
\hline Sound/Buried & 3 & 3 & 3 & 9 & 3 & 0 & 2 & 5 & 2 & 3 & 8 & 13 \\
\hline Notched/Surface & 2 & 3 & 11 & 16 & 1 & 1 & 2 & 4 & 2 & 1 & 36 & 39 \\
\hline Sound/Surface & 1 & 4 & 14 & 19 & 6 & 1 & 4 & 11 & 5 & 2 & 34 & 41 \\
\hline Total & 10 & 13 & 29 & 52 & 11 & 4 & 8 & 23 & 12 & 7 & 92 & 111 \\
\hline
\end{tabular}




\section{Appendix B \\ Tables: Germination Rates of Acorns by Harvest Date, Site, Treatment, and Condition.}


Table B.1. Germination rates for all three sites by treatment and harvest date.

\begin{tabular}{|l|c|c|c|c|c|c|c|c|c|}
\hline \multicolumn{7}{|c|}{ Germination Rates by Site and Time of Year } \\
\hline Treatment & \multicolumn{3}{|c|}{ Lick Run } & \multicolumn{3}{c|}{ Glade Run } & \multicolumn{3}{c|}{ Laurel Run } \\
\hline & December & March & June & December & March & June & December & March & June \\
\hline Notched & $3 \%$ & $92 \%$ & $93 \%$ & $11 \%$ & $68 \%$ & $99 \%$ & $2 \%$ & $73 \%$ & $54 \%$ \\
\hline Sound & $2 \%$ & $93 \%$ & $93 \%$ & $19 \%$ & $78 \%$ & $99 \%$ & $5 \%$ & $88 \%$ & $70 \%$ \\
\hline Buried & $3 \%$ & $97 \%$ & $98 \%$ & $23 \%$ & $79 \%$ & $100 \%$ & $6 \%$ & $99 \%$ & $82 \%$ \\
\hline Surface & $2 \%$ & $88 \%$ & $88 \%$ & $7 \%$ & $67 \%$ & $98 \%$ & $1 \%$ & $62 \%$ & $43 \%$ \\
\hline Notched-Buried & $3 \%$ & $100 \%$ & $100 \%$ & $18 \%$ & $78 \%$ & $100 \%$ & $2 \%$ & $100 \%$ & $77 \%$ \\
\hline Sound-Buried & $2 \%$ & $83 \%$ & $87 \%$ & $3 \%$ & $58 \%$ & $98 \%$ & $2 \%$ & $48 \%$ & $32 \%$ \\
\hline Notched-Surface & $2 \%$ & $93 \%$ & $95 \%$ & $30 \%$ & $80 \%$ & $100 \%$ & $10 \%$ & $98 \%$ & $87 \%$ \\
\hline Sound-Surface & $2 \%$ & $93 \%$ & $90 \%$ & $8 \%$ & $75 \%$ & $98 \%$ & $0 \%$ & $75 \%$ & $53 \%$ \\
\hline Overall \% & $\mathbf{2 \%}$ & $\mathbf{9 3 \%}$ & $\mathbf{9 3 \%}$ & $\mathbf{1 5 \%}$ & $\mathbf{7 3 \%}$ & $\mathbf{9 9 \%}$ & $\mathbf{4 \%}$ & $\mathbf{8 0 \%}$ & $\mathbf{6 2 \%}$ \\
\hline
\end{tabular}

Table B.2. Germination rates for Sound acorns for all three sites by treatment and harvest date.

\begin{tabular}{|l|c|c|c|c|c|c|c|c|c|}
\hline \multicolumn{7}{|c|}{ Germination Rates of Sound Acorns } \\
\hline Treatment & \multicolumn{3}{|c|}{ Lick Run } & \multicolumn{3}{c|}{ Glade Run } & \multicolumn{3}{c|}{ Laurel Run } \\
\hline & December & March & June & December & March & June & December & March & June \\
\hline Notched & $3 \%$ & $91 \%$ & $98 \%$ & $8 \%$ & $89 \%$ & $99 \%$ & $2 \%$ & $90 \%$ & $81 \%$ \\
\hline Sound & $0 \%$ & $98 \%$ & $96 \%$ & $17 \%$ & $97 \%$ & $99 \%$ & $5 \%$ & $89 \%$ & $75 \%$ \\
\hline Buried & $2 \%$ & $100 \%$ & $99 \%$ & $21 \%$ & $99 \%$ & $100 \%$ & $6 \%$ & $100 \%$ & $94 \%$ \\
\hline Surface & $1 \%$ & $90 \%$ & $94 \%$ & $5 \%$ & $87 \%$ & $97 \%$ & $1 \%$ & $75 \%$ & $32 \%$ \\
\hline Notched-Buried & $4 \%$ & $100 \%$ & $100 \%$ & $14 \%$ & $98 \%$ & $100 \%$ & $2 \%$ & $100 \%$ & $95 \%$ \\
\hline Sound-Buried & $2 \%$ & $82 \%$ & $95 \%$ & $2 \%$ & $80 \%$ & $97 \%$ & $2 \%$ & $71 \%$ & $20 \%$ \\
\hline Notched-Surface & $0 \%$ & $100 \%$ & $98 \%$ & $27 \%$ & $100 \%$ & $100 \%$ & $10 \%$ & $100 \%$ & $93 \%$ \\
\hline Sound-Surface & $0 \%$ & $96 \%$ & $94 \%$ & $7 \%$ & $94 \%$ & $97 \%$ & $0 \%$ & $77 \%$ & $36 \%$ \\
\hline Overall \% & $\mathbf{1 \%}$ & $\mathbf{9 5 \%}$ & $\mathbf{9 7 \%}$ & $\mathbf{1 3 \%}$ & $\mathbf{9 3 \%}$ & $\mathbf{9 9 \%}$ & $\mathbf{4 \%}$ & $\mathbf{8 9 \%}$ & $\mathbf{7 7 \%}$ \\
\hline
\end{tabular}

Table B.3. Germination rates for acorns with discolored cotyledons for all three sites by treatment and harvest date.

\begin{tabular}{|l|c|c|c|c|c|c|c|c|c|}
\hline \multicolumn{8}{|c|}{ Germination Rates of Acorns with Cotyledon Discoloration } \\
\hline Treatment & \multicolumn{3}{|c|}{ Lick Run } & \multicolumn{3}{c|}{ Glade Run } & \multicolumn{3}{c|}{ Laurel Run } \\
\hline & December & March & June & December & March & June & December & March & June \\
\hline Notched & $0 \%$ & $79 \%$ & $73 \%$ & $20 \%$ & $70 \%$ & $95 \%$ & $0 \%$ & $29 \%$ & $63 \%$ \\
\hline Sound & $0 \%$ & $45 \%$ & $79 \%$ & $20 \%$ & $75 \%$ & $100 \%$ & $0 \%$ & $75 \%$ & $62 \%$ \\
\hline Buried & $0 \%$ & $67 \%$ & $88 \%$ & $50 \%$ & $100 \%$ & $100 \%$ & $0 \%$ & $83 \%$ & $82 \%$ \\
\hline Surface & $0 \%$ & $62 \%$ & $71 \%$ & $13 \%$ & $60 \%$ & $95 \%$ & $0 \%$ & $31 \%$ & $14 \%$ \\
\hline Notched-Buried & $0 \%$ & $100 \%$ & $100 \%$ & NA & $100 \%$ & $100 \%$ & $0 \%$ & $100 \%$ & $80 \%$ \\
\hline Sound-Buried & $0 \%$ & $70 \%$ & $57 \%$ & $40 \%$ & $57 \%$ & $93 \%$ & $0 \%$ & $23 \%$ & $14 \%$ \\
\hline Notched-Surface & $0 \%$ & $50 \%$ & $78 \%$ & $50 \%$ & $100 \%$ & $100 \%$ & NA & $67 \%$ & $86 \%$ \\
\hline Sound-Surface & NA & $33 \%$ & $80 \%$ & $0 \%$ & $67 \%$ & $100 \%$ & $0 \%$ & $80 \%$ & $14 \%$ \\
\hline Overall \% & $\mathbf{0 \%}$ & $\mathbf{6 4 \%}$ & $\mathbf{7 6 \%}$ & $\mathbf{3 0 \%}$ & $\mathbf{7 1 \%}$ & $\mathbf{9 7 \%}$ & $\mathbf{0 \%}$ & $\mathbf{3 8 \%}$ & $\mathbf{6 3 \%}$ \\
\hline
\end{tabular}


Table B.4. Germination rates for acorns with cotyledon discoloration and weevil damage for all three sites by treatment and harvest date.

\begin{tabular}{|l|c|c|c|c|c|c|c|c|c|}
\hline \multicolumn{9}{|c|}{ Germination Rates of Acorns with Cotyledon Discoloration and Weevil Damage } \\
\hline Treatment & \multicolumn{3}{|c|}{ Lick Run } & \multicolumn{3}{c|}{ Glade Run } & \multicolumn{3}{c|}{ Laurel Run } \\
\hline & December & March & June & December & March & June & December & March & June \\
\hline Notched & NA & NA & $75 \%$ & NA & NA & $100 \%$ & NA & $0 \%$ & $29 \%$ \\
\hline Sound & NA & NA & $100 \%$ & NA & $100 \%$ & $100 \%$ & NA & NA & $69 \%$ \\
\hline Buried & NA & NA & NA & NA & NA & $100 \%$ & NA & $0 \%$ & $100 \%$ \\
\hline Surface & NA & NA & $88 \%$ & NA & $100 \%$ & $100 \%$ & NA & NA & $6 \%$ \\
\hline Notched-Buried & NA & NA & NA & NA & NA & $100 \%$ & NA & $0 \%$ & $100 \%$ \\
\hline Sound-Buried & NA & NA & $75 \%$ & NA & NA & $100 \%$ & NA & NA & $0 \%$ \\
\hline Notched-Surface & NA & NA & NA & NA & NA & $100 \%$ & NA & NA & $100 \%$ \\
\hline Sound-Surface & NA & NA & $100 \%$ & NA & $100 \%$ & $100 \%$ & NA & NA & $20 \%$ \\
\hline Overall \% & NA & NA & $\mathbf{8 8 \%}$ & NA & NA & $\mathbf{1 0 0 \%}$ & NA & NA & $\mathbf{4 7 \%}$ \\
\hline
\end{tabular}

Table B.5. Germination rates for weevil damaged acorns for all three sites by treatment and harvest date.

\begin{tabular}{|l|c|c|c|c|c|c|c|c|c|}
\hline \multicolumn{8}{|c|}{ Germination Rates of Weevil Damaged Acorns } \\
\hline Treatment & \multicolumn{3}{|c|}{ Lick Run } & \multicolumn{3}{c|}{ Glade Run } & \multicolumn{3}{c|}{ Laurel Run } \\
\hline & December & March & June & December & March & June & December & March & June \\
\hline Notched & $0 \%$ & $100 \%$ & $100 \%$ & $33 \%$ & $100 \%$ & $100 \%$ & $0 \%$ & $100 \%$ & $12 \%$ \\
\hline Sound & $11 \%$ & $100 \%$ & $100 \%$ & $67 \%$ & $86 \%$ & $100 \%$ & $0 \%$ & $80 \%$ & $24 \%$ \\
\hline Buried & $25 \%$ & $100 \%$ & $100 \%$ & $57 \%$ & $100 \%$ & $100 \%$ & $0 \%$ & $100 \%$ & $9 \%$ \\
\hline Surface & $0 \%$ & $100 \%$ & $100 \%$ & $0 \%$ & $86 \%$ & $100 \%$ & $0 \%$ & $67 \%$ & $20 \%$ \\
\hline Notched-Buried & $0 \%$ & $100 \%$ & NA & $50 \%$ & $100 \%$ & $100 \%$ & $0 \%$ & $100 \%$ & $7 \%$ \\
\hline Sound-Buried & $0 \%$ & $100 \%$ & $100 \%$ & $0 \%$ & $100 \%$ & $100 \%$ & $0 \%$ & $100 \%$ & $14 \%$ \\
\hline Notched-Surface & $33 \%$ & $100 \%$ & $100 \%$ & $67 \%$ & $100 \%$ & $100 \%$ & $0 \%$ & $100 \%$ & $13 \%$ \\
\hline Sound-Surface & $0 \%$ & $100 \%$ & $100 \%$ & $0 \%$ & $75 \%$ & $100 \%$ & $0 \%$ & $50 \%$ & $26 \%$ \\
\hline Overall \% & $\mathbf{9 \%}$ & $\mathbf{1 0 0 \%}$ & $\mathbf{1 0 0 \%}$ & $\mathbf{4 4 \%}$ & $\mathbf{9 2 \%}$ & $\mathbf{1 0 0 \%}$ & $\mathbf{0 \%}$ & $\mathbf{8 6 \%}$ & $\mathbf{1 7 \%}$ \\
\hline
\end{tabular}

Table B.6. Germination rates at Glade Run by harvest date and treatments.

\begin{tabular}{|l|c|c|c|c|c|c|c|c|c|}
\hline \multicolumn{10}{|c|}{ Glade Run Germination Rates } \\
\hline Treatment & \multicolumn{2}{|c|}{ December-Harvested } & \multicolumn{2}{|c|}{ March-Harvested } & \multicolumn{3}{c|}{ June-Harvested } \\
\hline & \# Germ. Total & \% Germ. & \# Germ. & Total & \% Germ. & \# Germ. & Total & \% Germ. \\
\hline Notched & 13 & 120 & $\mathbf{1 1 \%}$ & 82 & 120 & $\mathbf{6 8 \%}$ & 119 & 120 & $\mathbf{9 9 \%}$ \\
\hline Sound & 23 & 120 & $\mathbf{1 9 \%}$ & 93 & 120 & $\mathbf{7 8 \%}$ & 119 & 120 & $\mathbf{9 9 \%}$ \\
\hline Buried & 28 & 120 & $\mathbf{2 3 \%}$ & 95 & 120 & $\mathbf{7 9 \%}$ & 120 & 120 & $\mathbf{1 0 0 \%}$ \\
\hline Surface & 8 & 120 & $\mathbf{7 \%}$ & 80 & 120 & $\mathbf{6 7 \%}$ & 118 & 120 & $\mathbf{9 8 \%}$ \\
\hline Notched/Buried & 11 & 60 & $\mathbf{1 8 \%}$ & 47 & 60 & $\mathbf{7 8 \%}$ & 60 & 60 & $\mathbf{1 0 0 \%}$ \\
\hline Sound/Buried & 2 & 60 & $\mathbf{3 \%}$ & 35 & 60 & $\mathbf{5 8 \%}$ & 59 & 60 & $\mathbf{9 8 \%}$ \\
\hline Notched/Surface & 18 & 60 & $\mathbf{3 0 \%}$ & 48 & 60 & $\mathbf{8 0 \%}$ & 60 & 60 & $\mathbf{1 0 0 \%}$ \\
\hline Sound/Surface & 5 & 60 & $\mathbf{8 \%}$ & 45 & 60 & $\mathbf{7 5 \%}$ & 59 & 60 & $\mathbf{9 8 \%}$ \\
\hline Total & $\mathbf{3 6}$ & $\mathbf{2 4 0}$ & $\mathbf{1 5 \%}$ & $\mathbf{1 7 5}$ & $\mathbf{2 4 0}$ & $\mathbf{7 3 \%}$ & $\mathbf{2 3 8}$ & $\mathbf{2 4 0}$ & $\mathbf{9 9 \%}$ \\
\hline
\end{tabular}


Table B.7. Germination rates at Lick Run by harvest date and treatments.

\begin{tabular}{|l|c|c|c|c|c|c|c|c|c|}
\hline \multicolumn{7}{|c|}{ Lick Run Germination Rates } \\
\hline Treatment & \multicolumn{2}{|c|}{ December-Harvested } & \multicolumn{2}{|c|}{ March-Harvested } & \multicolumn{3}{c|}{ June-Harvested } \\
\hline & \# Germ. & Total & $\mathbf{\%}$ Germ. & \# Germ. & Total & \% Germ. & \# Germ. & Total & \% Germ. \\
\hline Notched & 3 & 120 & $\mathbf{3 \%}$ & 110 & 120 & $\mathbf{9 2 \%}$ & 112 & 120 & $\mathbf{9 3 \%}$ \\
\hline Sound & 2 & 120 & $\mathbf{2 \%}$ & 112 & 120 & $\mathbf{9 3 \%}$ & 111 & 120 & $\mathbf{9 3 \%}$ \\
\hline Buried & 3 & 120 & $\mathbf{3 \%}$ & 116 & 120 & $\mathbf{9 7 \%}$ & 117 & 120 & $\mathbf{9 8 \%}$ \\
\hline Surface & 2 & 120 & $\mathbf{2 \%}$ & 106 & 120 & $\mathbf{8 8 \%}$ & 106 & 120 & $\mathbf{8 8 \%}$ \\
\hline Notched/Buried & 2 & 60 & $\mathbf{3 \%}$ & 60 & 60 & $\mathbf{1 0 0 \%}$ & 60 & 60 & $\mathbf{1 0 0 \%}$ \\
\hline Sound/Buried & 1 & 60 & $\mathbf{2 \%}$ & 50 & 60 & $\mathbf{8 3 \%}$ & 52 & 60 & $\mathbf{8 7 \%}$ \\
\hline Notched/Surface & 1 & 60 & $\mathbf{2 \%}$ & 56 & 60 & $\mathbf{9 3 \%}$ & 57 & 60 & $\mathbf{9 5 \%}$ \\
\hline Sound/Surface & 1 & 60 & $\mathbf{2 \%}$ & 56 & 60 & $\mathbf{9 3 \%}$ & 54 & 60 & $\mathbf{9 0 \%}$ \\
\hline Total & $\mathbf{5}$ & $\mathbf{2 4 0}$ & $\mathbf{2 \%}$ & $\mathbf{2 2 2}$ & $\mathbf{2 4 0}$ & $\mathbf{9 3 \%}$ & $\mathbf{2 2 3}$ & $\mathbf{2 4 0}$ & $\mathbf{9 3 \%}$ \\
\hline
\end{tabular}

Table B.8. Germination rates at Laurel Run by harvest date and treatments.

\begin{tabular}{|c|c|c|c|c|c|c|c|c|c|}
\hline \multicolumn{10}{|c|}{ Laurel Run Germination Rates } \\
\hline \multirow[t]{2}{*}{ Treatment } & \multicolumn{3}{|c|}{ December-Harvested } & \multicolumn{3}{|c|}{ March-Harvested } & \multicolumn{3}{|c|}{ June-Harvested } \\
\hline & \# Germ. & Total & $\%$ Germ. & \# Germ. & Total & \% Germ. & \# Germ. & Total & $\%$ Germ. \\
\hline Notched & 2 & 120 & $2 \%$ & 88 & 120 & $\mathbf{7 3 \%}$ & 65 & 120 & $54 \%$ \\
\hline Sound & 6 & 120 & $5 \%$ & 105 & 120 & $88 \%$ & 84 & 120 & $70 \%$ \\
\hline Buried & 7 & 120 & $6 \%$ & 119 & 120 & $99 \%$ & 98 & 120 & $82 \%$ \\
\hline Surface & 1 & 120 & $1 \%$ & 74 & 120 & $62 \%$ & 51 & 120 & $43 \%$ \\
\hline Notched/Buried & 1 & 60 & $2 \%$ & 60 & 60 & $100 \%$ & 46 & 60 & $77 \%$ \\
\hline Sound/Buried & 1 & 60 & $2 \%$ & 29 & 60 & $48 \%$ & 19 & 60 & $32 \%$ \\
\hline Notched/Surface & 6 & 60 & $10 \%$ & 59 & 60 & $98 \%$ & 52 & 60 & $87 \%$ \\
\hline Sound/Surface & 0 & 60 & $\mathbf{0 \%}$ & 45 & 60 & $75 \%$ & 32 & 60 & $53 \%$ \\
\hline Total & 8 & 240 & $3 \%$ & 193 & 240 & $80 \%$ & 149 & 240 & $62 \%$ \\
\hline
\end{tabular}

Table B.9. Germination rates of Glade Run sound acorns by harvest date, and treatment.

\begin{tabular}{|l|c|c|c|c|c|c|c|c|c|}
\hline & \multicolumn{9}{|c|}{ Glade Sound Acorns } \\
\hline Treatment & \multicolumn{1}{|c|}{ December-Harvested } & \multicolumn{2}{c|}{ March-Harvested } & \multicolumn{3}{c|}{ June-Harvested } \\
\hline & \# Germ. & Total & \% Germ. & \# Germ. & Total & \% Germ. & \# Germ. & Total & \% Germ. \\
\hline Notched & 9 & 110 & $\mathbf{8 \%}$ & 93 & 104 & $\mathbf{8 9 \%}$ & 84 & 85 & $\mathbf{9 9 \%}$ \\
\hline Sound & 19 & 111 & $\mathbf{1 7 \%}$ & 105 & 108 & $\mathbf{9 7 \%}$ & 84 & 85 & $\mathbf{9 9 \%}$ \\
\hline Buried & 23 & 111 & $\mathbf{2 1 \%}$ & 109 & 110 & $\mathbf{9 9 \%}$ & 106 & 106 & $\mathbf{1 0 0 \%}$ \\
\hline Surface & 5 & 110 & $\mathbf{5 \%}$ & 89 & 102 & $\mathbf{8 7 \%}$ & 62 & 64 & $\mathbf{9 7 \%}$ \\
\hline Notched/Buried & 8 & 56 & $\mathbf{1 4 \%}$ & 53 & 54 & $\mathbf{9 8 \%}$ & 54 & 54 & $\mathbf{1 0 0 \%}$ \\
\hline Sound/Buried & 1 & 54 & $\mathbf{2 \%}$ & 40 & 50 & $\mathbf{8 0 \%}$ & 30 & 31 & $\mathbf{9 7 \%}$ \\
\hline Notched/Surface & 15 & 55 & $\mathbf{2 7 \%}$ & 56 & 56 & $\mathbf{1 0 0 \%}$ & 52 & 52 & $\mathbf{1 0 0 \%}$ \\
\hline Sound/Surface & 4 & 56 & $\mathbf{7 \%}$ & 49 & 52 & $\mathbf{9 4 \%}$ & 32 & 33 & $\mathbf{9 7 \%}$ \\
\hline Overall \% & $\mathbf{2 8}$ & $\mathbf{2 2 1}$ & $\mathbf{1 3 \%}$ & $\mathbf{1 9 8}$ & $\mathbf{2 1 2}$ & $\mathbf{9 3 \%}$ & $\mathbf{1 6 8}$ & $\mathbf{1 7 0}$ & $\mathbf{9 9 \%}$ \\
\hline
\end{tabular}


Table B.10. Germination rates of Lick Run sound acorns by harvest date, and treatment.

\begin{tabular}{|l|c|c|c|c|c|c|c|c|c|}
\hline & \multicolumn{9}{|c|}{ Lick Run Sound Acorns } \\
\hline & \multicolumn{1}{|c|}{ December-Harvested } & \multicolumn{2}{|c|}{ March-Harvested } & \multicolumn{3}{c|}{ June-Harvested } \\
\hline & \# Germ. & Total & \% Germ. & \# Germ. & Total & $\mathbf{\%}$ Germ. & \# Germ. & Total & \% Germ. \\
\hline Notched & 3 & 109 & $\mathbf{3 \%}$ & 94 & 103 & $\mathbf{9 1 \%}$ & 90 & 92 & $\mathbf{9 8 \%}$ \\
\hline Sound & 0 & 107 & $\mathbf{0 \%}$ & 106 & 108 & $\mathbf{9 8 \%}$ & 78 & 81 & $\mathbf{9 6 \%}$ \\
\hline Buried & 2 & 106 & $\mathbf{2 \%}$ & 106 & 106 & $\mathbf{1 0 0 \%}$ & 100 & 101 & $\mathbf{9 9 \%}$ \\
\hline Surface & 1 & 110 & $\mathbf{1 \%}$ & 94 & 105 & $\mathbf{9 0 \%}$ & 68 & 72 & $\mathbf{9 4 \%}$ \\
\hline Notched/Buried & 2 & 53 & $\mathbf{4 \%}$ & 54 & 54 & $\mathbf{1 0 0 \%}$ & 52 & 52 & $\mathbf{1 0 0 \%}$ \\
\hline Sound/Buried & 1 & 56 & $\mathbf{2 \%}$ & 40 & 49 & $\mathbf{8 2 \%}$ & 38 & 40 & $\mathbf{9 5 \%}$ \\
\hline Notched/Surface & 0 & 53 & $\mathbf{0 \%}$ & 52 & 52 & $\mathbf{1 0 0 \%}$ & 48 & 49 & $\mathbf{9 8 \%}$ \\
\hline Sound/Surface & 0 & 54 & $\mathbf{0 \%}$ & 54 & 56 & $\mathbf{9 6 \%}$ & 30 & 32 & $\mathbf{9 4 \%}$ \\
\hline Overall \% & $\mathbf{3}$ & $\mathbf{2 1 6}$ & $\mathbf{1 \%}$ & $\mathbf{2 0 0}$ & $\mathbf{2 1 1}$ & $\mathbf{9 5 \%}$ & $\mathbf{1 6 8}$ & $\mathbf{1 7 3}$ & $\mathbf{9 7 \%}$ \\
\hline
\end{tabular}

Table B.11. Germination rates of Laurel Run sound acorns by harvest date, and treatment.

\begin{tabular}{|l|c|c|c|c|c|c|c|c|c|}
\hline & \multicolumn{7}{|c|}{ Laurel Run Sound Acorns } \\
\hline Treatment & \multicolumn{2}{|c|}{ December-Harvested } & \multicolumn{2}{|c|}{ March-Harvested } & \multicolumn{3}{c|}{ June-Harvested } \\
\hline & \# Germ. & Total & \% Germ. & \# Germ. & Total & \% Germ. & \# Germ. & Total & \% Germ. \\
\hline Notched & 2 & 98 & $\mathbf{2 \%}$ & 75 & 83 & $\mathbf{9 0 \%}$ & 21 & 26 & $\mathbf{8 1 \%}$ \\
\hline Sound & 6 & 110 & $\mathbf{5 \%}$ & 95 & 107 & $\mathbf{8 9 \%}$ & 33 & 44 & $\mathbf{7 5 \%}$ \\
\hline Buried & 7 & 113 & $\mathbf{6 \%}$ & 109 & 109 & $\mathbf{1 0 0 \%}$ & 48 & 51 & $\mathbf{9 4 \%}$ \\
\hline Surface & 1 & 95 & $\mathbf{1 \%}$ & 61 & 81 & $\mathbf{7 5 \%}$ & 6 & 19 & $\mathbf{3 2 \%}$ \\
\hline Notched/Buried & 1 & 55 & $\mathbf{2 \%}$ & 55 & 55 & $\mathbf{1 0 0 \%}$ & 20 & 21 & $\mathbf{9 5 \%}$ \\
\hline Sound/Buried & 1 & 43 & $\mathbf{2 \%}$ & 20 & 28 & $\mathbf{7 1 \%}$ & 1 & 5 & $\mathbf{2 0 \%}$ \\
\hline Notched/Surface & 6 & 58 & $\mathbf{1 0 \%}$ & 54 & 54 & $\mathbf{1 0 0 \%}$ & 28 & 30 & $\mathbf{9 3 \%}$ \\
\hline Sound/Surface & 0 & 52 & $\mathbf{0 \%}$ & 41 & 53 & $\mathbf{7 7 \%}$ & 5 & 14 & $\mathbf{3 6 \%}$ \\
\hline Overall \% & $\mathbf{8}$ & $\mathbf{2 0 8}$ & $\mathbf{4 \%}$ & $\mathbf{1 7 0}$ & $\mathbf{1 9 0}$ & $\mathbf{8 9 \%}$ & $\mathbf{5 4}$ & $\mathbf{7 0}$ & $\mathbf{7 7 \%}$ \\
\hline
\end{tabular}

Table B.12. Germination rates of Glade Run acorns with cotyledon discoloration by harvest date, and treatment.

\begin{tabular}{|l|c|c|c|c|c|c|c|c|c|}
\hline \multicolumn{10}{|c|}{ Glade Run Acorns with Discolored Cotyledons } \\
\hline & \multicolumn{2}{|c|}{ December-Harvested } & \multicolumn{2}{|c|}{ March-Harvested } & \multicolumn{3}{c|}{ June-Harvested } \\
\hline & \# Germ. & Total & \% Germ. & \# Germ. & Total & $\mathbf{\%}$ Germ. & \# Germ. & Total & \% Germ. \\
\hline Notched & 1 & 5 & $\mathbf{2 0 \%}$ & 7 & 10 & $\mathbf{7 0 \%}$ & 18 & 19 & $\mathbf{9 5 \%}$ \\
\hline Sound & 1 & 5 & $\mathbf{2 0 \%}$ & 3 & 4 & $\mathbf{7 5 \%}$ & 12 & 12 & $\mathbf{1 0 0 \%}$ \\
\hline Buried & 1 & 2 & $\mathbf{5 0 \%}$ & 4 & 4 & $\mathbf{1 0 0 \%}$ & 9 & 9 & $\mathbf{1 0 0 \%}$ \\
\hline Surface & 1 & 8 & $\mathbf{1 3 \%}$ & 6 & 10 & $\mathbf{6 0 \%}$ & 21 & 22 & $\mathbf{9 5 \%}$ \\
\hline Notched/Buried & 0 & 0 & NA & 3 & 3 & $\mathbf{1 0 0 \%}$ & 5 & 5 & $\mathbf{1 0 0 \%}$ \\
\hline Sound/Buried & 2 & 5 & $\mathbf{4 0 \%}$ & 4 & 7 & $\mathbf{5 7 \%}$ & 13 & 14 & $\mathbf{9 3 \%}$ \\
\hline Notched/Surface & 1 & 2 & $\mathbf{5 0 \%}$ & 1 & 1 & $\mathbf{1 0 0 \%}$ & 4 & 4 & $\mathbf{1 0 0 \%}$ \\
\hline Sound/Surface & 0 & 3 & $\mathbf{0 \%}$ & 2 & 3 & $\mathbf{6 7 \%}$ & 8 & 8 & $\mathbf{1 0 0 \%}$ \\
\hline Overall \% & $\mathbf{3}$ & $\mathbf{1 0}$ & $\mathbf{3 0 \%}$ & $\mathbf{1 0}$ & $\mathbf{1 4}$ & $\mathbf{7 1 \%}$ & $\mathbf{3 0}$ & $\mathbf{3 1}$ & $\mathbf{9 7 \%}$ \\
\hline
\end{tabular}


Table B.13. Germination rates of Lick Run acorns with cotyledon discoloration by harvest date, and treatment.

\begin{tabular}{|l|c|c|c|c|c|c|c|c|c|}
\hline \multicolumn{10}{|c|}{ Lick Run Acorns with Discolored Cotyledon } \\
\hline & \multicolumn{2}{|c|}{ December-Harvested } & \multicolumn{2}{|c|}{ March-Harvested } & \multicolumn{3}{c|}{ June-Harvested } \\
\hline & \# Germ. & Total & \% Germ. & \# Germ. & Total & \% Germ. & \# Germ. & Total & \% Germ. \\
\hline Notched & 0 & 9 & $\mathbf{0 \%}$ & 11 & 14 & $\mathbf{7 9 \%}$ & 16 & 22 & $\mathbf{7 3 \%}$ \\
\hline Sound & 0 & 4 & $\mathbf{0 \%}$ & 5 & 11 & $\mathbf{4 5 \%}$ & 23 & 29 & $\mathbf{7 9 \%}$ \\
\hline Buried & 0 & 10 & $\mathbf{0 \%}$ & 8 & 12 & $\mathbf{6 7 \%}$ & 15 & 17 & $\mathbf{8 8 \%}$ \\
\hline Surface & 0 & 3 & $\mathbf{0 \%}$ & 8 & 13 & $\mathbf{6 2 \%}$ & 24 & 34 & $\mathbf{7 1 \%}$ \\
\hline Notched/Buried & 0 & 6 & $\mathbf{0 \%}$ & 4 & 4 & $\mathbf{1 0 0 \%}$ & 8 & 8 & $\mathbf{1 0 0 \%}$ \\
\hline Sound/Buried & 0 & 3 & $\mathbf{0 \%}$ & 7 & 10 & $\mathbf{7 0 \%}$ & 8 & 14 & $\mathbf{5 7 \%}$ \\
\hline Notched/Surface & 0 & 4 & $\mathbf{0 \%}$ & 4 & 8 & $\mathbf{5 0 \%}$ & 7 & 9 & $\mathbf{7 8 \%}$ \\
\hline Sound/Surface & 0 & 0 & NA & 1 & 3 & $\mathbf{3 3 \%}$ & 16 & 20 & $\mathbf{8 0 \%}$ \\
\hline Overall \% & $\mathbf{0}$ & $\mathbf{1 3}$ & $\mathbf{0 \%}$ & $\mathbf{1 6}$ & $\mathbf{2 5}$ & $\mathbf{6 4 \%}$ & $\mathbf{3 9}$ & $\mathbf{5 1}$ & $\mathbf{7 6 \%}$ \\
\hline
\end{tabular}

Table B.14. Germination rates of Laurel Run acorns with cotyledon discoloration by harvest date, and treatment.

\begin{tabular}{|l|c|c|c|c|c|c|c|c|c|}
\hline \multicolumn{8}{|c|}{ Laurel Run Acorns with Discolored Cotyledons } \\
\hline & \multicolumn{2}{|c|}{ December-Harvested } & \multicolumn{2}{|c|}{ March-Harvested } & \multicolumn{3}{c|}{ June-Harvested } \\
\hline & \# Germ. & Total & \% Germ. & \# Germ. & Total & \% Germ. & \# Germ. & Total & \% Germ. \\
\hline Notched & 0 & 17 & $\mathbf{0 \%}$ & 10 & 34 & $\mathbf{2 9 \%}$ & 17 & 27 & $\mathbf{6 3 \%}$ \\
\hline Sound & 0 & 3 & $\mathbf{0 \%}$ & 6 & 8 & $\mathbf{7 5 \%}$ & 13 & 21 & $\mathbf{6 2 \%}$ \\
\hline Buried & 0 & 5 & $\mathbf{0 \%}$ & 5 & 6 & $\mathbf{8 3 \%}$ & 28 & 34 & $\mathbf{8 2 \%}$ \\
\hline Surface & 0 & 15 & $\mathbf{0 \%}$ & 11 & 36 & $\mathbf{3 1 \%}$ & 2 & 14 & $\mathbf{1 4 \%}$ \\
\hline Notched/Buried & 0 & 2 & $\mathbf{0 \%}$ & 3 & 3 & $\mathbf{1 0 0 \%}$ & 16 & 20 & $\mathbf{8 0 \%}$ \\
\hline Sound/Buried & 0 & 15 & $\mathbf{0 \%}$ & 7 & 31 & $\mathbf{2 3 \%}$ & 1 & 7 & $\mathbf{1 4 \%}$ \\
\hline Notched/Surface & 0 & 0 & NA & 2 & 3 & $\mathbf{6 7 \%}$ & 12 & 14 & $\mathbf{8 6 \%}$ \\
\hline Sound/Surface & 0 & 3 & $\mathbf{0 \%}$ & 4 & 5 & $\mathbf{8 0 \%}$ & 1 & 7 & $\mathbf{1 4 \%}$ \\
\hline Overall \% & $\mathbf{0}$ & $\mathbf{2 0}$ & $\mathbf{0 \%}$ & $\mathbf{1 6}$ & $\mathbf{4 2}$ & $\mathbf{3 8 \%}$ & $\mathbf{3 0}$ & $\mathbf{4 8}$ & $\mathbf{6 3 \%}$ \\
\hline
\end{tabular}

Table B.15. Germination rates of Glade Run acorns with cotyledon discoloration and weevil damage by harvest date, and treatment.

\begin{tabular}{|l|c|c|c|c|c|c|c|c|c|}
\hline & \multicolumn{9}{|c|}{ Glade Run Acorns with Discoloration and Weevil Damage } \\
\hline Treatment & \multicolumn{3}{|c|}{ December-Harvested } & \multicolumn{2}{c|}{ March-Harvested } & \multicolumn{3}{c|}{ June-Harvested } \\
\hline & \# Germ. Total & \% Germ. & \# Germ. & Total & \% Germ. & \# Germ. & Total & \% Germ. \\
\hline Notched & 0 & 0 & NA & 0 & 0 & NA & 5 & 5 & $\mathbf{1 0 0 \%}$ \\
\hline Sound & 0 & 0 & NA & 1 & 1 & $\mathbf{1 0 0 \%}$ & 5 & 5 & $\mathbf{1 0 0 \%}$ \\
\hline Buried & 0 & 0 & NA & 0 & 0 & NA & 2 & 2 & $\mathbf{1 0 0 \%}$ \\
\hline Surface & 0 & 0 & NA & 1 & 1 & $\mathbf{1 0 0 \%}$ & 8 & 8 & $\mathbf{1 0 0 \%}$ \\
\hline Notched/Buried & 0 & 0 & NA & 0 & 0 & NA & 1 & 1 & $\mathbf{1 0 0 \%}$ \\
\hline Sound/Buried & 0 & 0 & NA & 0 & 0 & NA & 4 & 4 & $\mathbf{1 0 0 \%}$ \\
\hline Notched/Surface & 0 & 0 & NA & 0 & 0 & NA & 1 & 1 & $\mathbf{1 0 0 \%}$ \\
\hline Sound/Surface & 0 & 0 & NA & 1 & 1 & $\mathbf{1 0 0 \%}$ & 4 & 4 & $\mathbf{1 0 0 \%}$ \\
\hline Overall \% & $\mathbf{0}$ & $\mathbf{0}$ & NA & $\mathbf{0}$ & $\mathbf{0}$ & $\mathbf{1 0 0 \%}$ & $\mathbf{1 0}$ & $\mathbf{1 0}$ & $\mathbf{1 0 0 \%}$ \\
\hline
\end{tabular}


Table B.16. Germination rates of Lick Run acorns with cotyledon discoloration and weevil damage by harvest date, and treatment.

\begin{tabular}{|l|c|c|c|c|c|c|c|c|c|}
\hline & \multicolumn{6}{|c|}{ Lick Run Acorns with Discoloration and Weevil Damage } \\
\hline Treatment & \multicolumn{6}{|c|}{ December-Harvested } & \multicolumn{2}{c|}{ March-Harvested } & \multicolumn{3}{c|}{ June-Harvested } \\
\hline & \# Germ. & Total & \% Germ. & \# Germ. & Total & \% Germ. & \# Germ. & Total & \% Germ. \\
\hline Notched & 0 & 0 & NA & 0 & 0 & NA & 3 & 4 & $\mathbf{7 5 \%}$ \\
\hline Sound & 0 & 0 & NA & 0 & 0 & NA & 4 & 4 & $\mathbf{1 0 0 \%}$ \\
\hline Buried & 0 & 0 & NA & 0 & 0 & NA & 0 & 0 & NA \\
\hline Surface & 0 & 0 & NA & 0 & 0 & NA & 7 & 8 & $\mathbf{8 8 \%}$ \\
\hline Notched/Buried & 0 & 0 & NA & 0 & 0 & NA & 0 & 0 & NA \\
\hline Sound/Buried & 0 & 0 & NA & 0 & 0 & NA & 3 & 4 & $\mathbf{7 5 \%}$ \\
\hline Notched/Surface & 0 & 0 & NA & 0 & 0 & NA & 0 & 0 & NA \\
\hline Sound/Surface & 0 & 0 & NA & 0 & 0 & NA & 4 & 4 & $\mathbf{1 0 0 \%}$ \\
\hline Overall \% & $\mathbf{0}$ & $\mathbf{0}$ & NA & $\mathbf{0}$ & $\mathbf{0}$ & NA & $\mathbf{7}$ & $\mathbf{8}$ & $\mathbf{8 8 \%}$ \\
\hline
\end{tabular}

Table B.17. Germination rates of Laurel Run acorns with cotyledon discoloration and weevil damage by harvest date, and treatment.

\begin{tabular}{|l|c|c|c|c|c|c|c|c|c|}
\hline & \multicolumn{6}{|c|}{ Laurel Run Acorns with Discoloration and Weevil Damage } \\
\hline Treatment & \multicolumn{2}{|c|}{ December-Harvested } & \multicolumn{2}{|c|}{ March-Harvested } & \multicolumn{3}{c|}{ June-Harvested } \\
\hline & \# Germ. & Total & \% Germ. & \# Germ. & Total & \% Germ. & \# Germ. & Total & $\%$ Germ. \\
\hline Notched & 0 & 0 & NA & 0 & 1 & $\mathbf{0 \%}$ & 5 & 17 & $\mathbf{2 9 \%}$ \\
\hline Sound & 0 & 0 & NA & 0 & 0 & NA & 9 & 13 & $\mathbf{6 9 \%}$ \\
\hline Buried & 0 & 0 & NA & 0 & 1 & $\mathbf{0 \%}$ & 13 & 13 & $\mathbf{1 0 0 \%}$ \\
\hline Surface & 0 & 0 & NA & 0 & 0 & NA & 1 & 17 & $\mathbf{6 \%}$ \\
\hline Notched/Buried & 0 & 0 & NA & 0 & 1 & $\mathbf{0 \%}$ & 5 & 5 & $\mathbf{1 0 0 \%}$ \\
\hline Sound/Buried & 0 & 0 & NA & 0 & 0 & NA & 0 & 12 & $\mathbf{0 \%}$ \\
\hline Notched/Surface & 0 & 0 & NA & 0 & 0 & NA & 8 & 8 & $\mathbf{1 0 0 \%}$ \\
\hline Sound/Surface & 0 & 0 & NA & 0 & 0 & NA & 1 & 5 & $\mathbf{2 0 \%}$ \\
\hline Overall \% & $\mathbf{0}$ & $\mathbf{0}$ & NA & $\mathbf{0}$ & $\mathbf{0}$ & $\mathbf{0 \%}$ & $\mathbf{1 4}$ & $\mathbf{3 0}$ & $\mathbf{4 7 \%}$ \\
\hline
\end{tabular}

Table B.18. Germination rates of Glade Run weevil damaged acorns by harvest date, and treatment.

\begin{tabular}{|l|c|c|c|c|c|c|c|c|c|}
\hline & \multicolumn{9}{|c|}{ Glade Run Weevil Damaged Acorns } \\
\hline Treatment & \multicolumn{2}{|c|}{ December-Harvested } & \multicolumn{2}{c|}{ March-Harvested } & \multicolumn{3}{c|}{ June-Harvested } \\
\hline & \# Germ. & Total & \% Germ. & \# Germ. & Total & \% Germ. & \# Germ. & Total & \% Germ. \\
\hline Notched & 2 & 6 & $\mathbf{3 3 \%}$ & 6 & 6 & $\mathbf{1 0 0 \%}$ & 12 & 12 & $\mathbf{1 0 0 \%}$ \\
\hline Sound & 2 & 3 & $\mathbf{6 7 \%}$ & 6 & 7 & $\mathbf{8 6 \%}$ & 17 & 17 & $\mathbf{1 0 0 \%}$ \\
\hline Buried & 4 & 7 & $\mathbf{5 7 \%}$ & 6 & 6 & $\mathbf{1 0 0 \%}$ & 4 & 4 & $\mathbf{1 0 0 \%}$ \\
\hline Surface & 0 & 2 & $\mathbf{0 \%}$ & 6 & 7 & $\mathbf{8 6 \%}$ & 25 & 25 & $\mathbf{1 0 0 \%}$ \\
\hline Notched/Buried & 2 & 4 & $\mathbf{5 0 \%}$ & 3 & 3 & $\mathbf{1 0 0 \%}$ & 1 & 1 & $\mathbf{1 0 0 \%}$ \\
\hline Sound/Buried & 0 & 2 & $\mathbf{0 \%}$ & 3 & 3 & $\mathbf{1 0 0 \%}$ & 11 & 11 & $\mathbf{1 0 0 \%}$ \\
\hline Notched/Surface & 2 & 3 & $\mathbf{6 7 \%}$ & 3 & 3 & $\mathbf{1 0 0 \%}$ & 3 & 3 & $\mathbf{1 0 0 \%}$ \\
\hline Sound/Surface & 0 & 0 & $\mathbf{0 \%}$ & 3 & 4 & $\mathbf{7 5 \%}$ & 14 & 14 & $\mathbf{1 0 0 \%}$ \\
\hline Overall \% & $\mathbf{4}$ & $\mathbf{9}$ & $\mathbf{4 4 \%}$ & $\mathbf{1 2}$ & $\mathbf{1 3}$ & $\mathbf{9 2 \%}$ & $\mathbf{2 9}$ & $\mathbf{2 9}$ & $\mathbf{1 0 0 \%}$ \\
\hline
\end{tabular}


Table B.19. Germination rates of Lick Run weevil damaged acorns by harvest date, and treatment.

\begin{tabular}{|l|c|c|c|c|c|c|c|c|c|}
\hline & \multicolumn{8}{|c|}{ Lick Run Weevil Damaged Acorns } \\
\hline Treatment & \multicolumn{1}{|c|}{ December-Harvested } & \multicolumn{2}{c|}{ March-Harvested } & \multicolumn{3}{c|}{ June-Harvested } \\
\hline & \# Germ. & Total & \% Germ. & \# Germ. & Total & \% Germ. & \# Germ. & Total & \% Germ. \\
\hline Notched & 0 & 2 & $\mathbf{0 \%}$ & 2 & 2 & $\mathbf{1 0 0 \%}$ & 2 & 2 & $\mathbf{1 0 0 \%}$ \\
\hline Sound & 1 & 9 & $\mathbf{1 1 \%}$ & 2 & 2 & $\mathbf{1 0 0 \%}$ & 6 & 6 & $\mathbf{1 0 0 \%}$ \\
\hline Buried & 1 & 4 & $\mathbf{2 5 \%}$ & 2 & 2 & $\mathbf{1 0 0 \%}$ & 2 & 2 & $\mathbf{1 0 0 \%}$ \\
\hline Surface & 0 & 7 & $\mathbf{0 \%}$ & 2 & 2 & $\mathbf{1 0 0 \%}$ & 6 & 6 & $\mathbf{1 0 0 \%}$ \\
\hline Notched/Buried & 0 & 1 & $\mathbf{0 \%}$ & 1 & 1 & $\mathbf{1 0 0 \%}$ & 0 & 0 & NA \\
\hline Sound/Buried & 0 & 1 & $\mathbf{0 \%}$ & 1 & 1 & $\mathbf{1 0 0 \%}$ & 2 & 2 & $\mathbf{1 0 0 \%}$ \\
\hline Notched/Surface & 1 & 3 & $\mathbf{3 3 \%}$ & 1 & 1 & $\mathbf{1 0 0 \%}$ & 2 & 2 & $\mathbf{1 0 0 \%}$ \\
\hline Sound/Surface & 0 & 6 & $\mathbf{0 \%}$ & 1 & 1 & $\mathbf{1 0 0 \%}$ & 4 & 4 & $\mathbf{1 0 0 \%}$ \\
\hline Overall \% & $\mathbf{1}$ & $\mathbf{1 1}$ & $\mathbf{9 \%}$ & $\mathbf{4}$ & $\mathbf{4}$ & $\mathbf{1 0 0 \%}$ & $\mathbf{8}$ & $\mathbf{8}$ & $\mathbf{1 0 0 \%}$ \\
\hline
\end{tabular}

Table B.20. Germination rates of Laurel Run weevil damaged acorns by harvest date, and treatment.

\begin{tabular}{|l|c|c|c|c|c|c|c|c|c|}
\hline & \multicolumn{8}{|c|}{ Laurel Run Weevil Damaged Acorns } \\
\hline & \multicolumn{2}{|c|}{ December-Harvested } & \multicolumn{2}{|c|}{ March-Harvested } & \multicolumn{2}{c|}{ June-Harvested } \\
\hline & \# Germ. & Total & \% Germ. & \# Germ. & Total & $\mathbf{\%}$ Germ. & \# Germ. & Total & \% Germ. \\
\hline Notched & 0 & 5 & $\mathbf{0 \%}$ & 2 & 2 & $\mathbf{1 0 0 \%}$ & 6 & 50 & $\mathbf{1 2 \%}$ \\
\hline Sound & 0 & 7 & $\mathbf{0 \%}$ & 4 & 5 & $\mathbf{8 0 \%}$ & 10 & 42 & $\mathbf{2 4 \%}$ \\
\hline Buried & 0 & 5 & $\mathbf{0 \%}$ & 4 & 4 & $\mathbf{1 0 0 \%}$ & 2 & 22 & $\mathbf{9 \%}$ \\
\hline Surface & 0 & 7 & $\mathbf{0 \%}$ & 2 & 3 & $\mathbf{6 7 \%}$ & 14 & 70 & $\mathbf{2 0 \%}$ \\
\hline Notched/Buried & 0 & 3 & $\mathbf{0 \%}$ & 1 & 1 & $\mathbf{1 0 0 \%}$ & 1 & 14 & $\mathbf{7 \%}$ \\
\hline Sound/Buried & 0 & 2 & $\mathbf{0 \%}$ & 1 & 1 & $\mathbf{1 0 0 \%}$ & 5 & 36 & $\mathbf{1 4 \%}$ \\
\hline Notched/Surface & 0 & 2 & $\mathbf{0 \%}$ & 3 & 3 & $\mathbf{1 0 0 \%}$ & 1 & 8 & $\mathbf{1 3 \%}$ \\
\hline Sound/Surface & 0 & 5 & $\mathbf{0 \%}$ & 1 & 2 & $\mathbf{5 0 \%}$ & 9 & 34 & $\mathbf{2 6 \%}$ \\
\hline Overall \% & $\mathbf{0}$ & $\mathbf{1 2}$ & $\mathbf{0 \%}$ & $\mathbf{6}$ & $\mathbf{7}$ & $\mathbf{8 6 \%}$ & $\mathbf{1 6}$ & $\mathbf{9 2}$ & $\mathbf{1 7 \%}$ \\
\hline
\end{tabular}

Table B.21. Overall germination rates by harvest date and treatments.

\begin{tabular}{|l|c|c|c|c|c|c|c|c|c|}
\hline & \multicolumn{8}{|c|}{ Germination Rates by Harvest Date } \\
\hline Treatment & \multicolumn{1}{|c|}{ December-Harvested } & \multicolumn{3}{c|}{ March-Harvested } & \multicolumn{3}{c|}{ June-Harvested } \\
\hline & \# Germ. & Total & \% Germ. & \# Germ. & Total & \% Germ. & \# Germ. & Total & \% Germ. \\
\hline Notched & 18 & 360 & $\mathbf{5 \%}$ & 280 & 360 & $\mathbf{7 8 \%}$ & 296 & 360 & $\mathbf{8 2 \%}$ \\
\hline Sound & 31 & 360 & $\mathbf{9 \%}$ & 310 & 360 & $\mathbf{8 6 \%}$ & 314 & 360 & $\mathbf{8 7 \%}$ \\
\hline Buried & 38 & 360 & $\mathbf{1 1 \%}$ & 330 & 360 & $\mathbf{9 2 \%}$ & 335 & 360 & $\mathbf{9 3 \%}$ \\
\hline Surface & 11 & 360 & $\mathbf{3 \%}$ & 260 & 360 & $\mathbf{7 2 \%}$ & 275 & 360 & $\mathbf{7 6 \%}$ \\
\hline Notched/Buried & 14 & 180 & $\mathbf{8 \%}$ & 167 & 180 & $\mathbf{9 3 \%}$ & 166 & 180 & $\mathbf{9 2 \%}$ \\
\hline Sound/Buried & 4 & 180 & $\mathbf{2 \%}$ & 114 & 180 & $\mathbf{6 3 \%}$ & 130 & 180 & $\mathbf{7 2 \%}$ \\
\hline Notched/Surface & 25 & 180 & $\mathbf{1 4 \%}$ & 163 & 180 & $\mathbf{9 1 \%}$ & 169 & 180 & $\mathbf{9 4 \%}$ \\
\hline Sound/Surface & 6 & 180 & $\mathbf{3 \%}$ & 146 & 180 & $\mathbf{8 1 \%}$ & 145 & 180 & $\mathbf{8 1 \%}$ \\
\hline Total & $\mathbf{4 9}$ & $\mathbf{7 2 0}$ & $\mathbf{7 \%}$ & $\mathbf{5 9 0}$ & $\mathbf{7 2 0}$ & $\mathbf{8 2 \%}$ & $\mathbf{6 1 0}$ & $\mathbf{7 2 0}$ & $\mathbf{8 5 \%}$ \\
\hline
\end{tabular}


Table B.22. Germination rates for acorns at all three sites by harvest date.

\begin{tabular}{|c|l|c|c|c|c|}
\hline Site & Time & \# Germinated & \# Failed & Total & \% Germinated \\
\hline \multirow{4}{*}{$\begin{array}{c}\text { Lick } \\
\text { Run }\end{array}$} & December & 5 & 235 & 240 & $\mathbf{2 \%}$ \\
\cline { 2 - 6 } & March & 222 & 18 & 240 & $\mathbf{9 3 \%}$ \\
\cline { 2 - 6 } & June & 223 & 17 & 240 & $\mathbf{9 3 \%}$ \\
\cline { 2 - 6 } & Total & $\mathbf{4 5 0}$ & $\mathbf{2 7 0}$ & $\mathbf{7 2 0}$ & $\mathbf{6 3 \%}$ \\
\hline \multirow{3}{*}{$\begin{array}{c}\text { Glade } \\
\text { Run }\end{array}$} & December & 36 & 204 & 240 & $\mathbf{1 5 \%}$ \\
\cline { 2 - 6 } & March & 174 & 66 & 240 & $\mathbf{7 3 \%}$ \\
\cline { 2 - 6 } & June & 238 & 2 & 240 & $\mathbf{9 9 \%}$ \\
\cline { 2 - 6 } & Total & $\mathbf{4 4 8}$ & $\mathbf{2 7 2}$ & $\mathbf{7 2 0}$ & $\mathbf{6 2 \%}$ \\
\hline \multirow{3}{*}{$\begin{array}{c}\text { Laurel } \\
\text { Run }\end{array}$} & December & 8 & 232 & 240 & $\mathbf{3 \%}$ \\
\cline { 2 - 6 } & March & 193 & 47 & 240 & $\mathbf{8 0 \%}$ \\
\cline { 2 - 6 } & June & 149 & $\mathbf{3 7 0}$ & $\mathbf{7 2 0}$ & $\mathbf{4 9 \%}$ \\
\cline { 2 - 6 } & Total & $\mathbf{3 5 0}$ & $\mathbf{9 1 2}$ & $\mathbf{2 1 6 0}$ & $\mathbf{5 8 \%}$ \\
\hline \multirow{2}{*}{ Overall Totals } & $\mathbf{1 2 4 8}$ & & & \\
\hline
\end{tabular}


Appendix C

Figures: Frequency of Fungi Isolated by Site and Harvest Date for Acorns with Cotyledon Discoloration 
Figure C.1: Frequency of Fungi from Isolated from December-Harvested Acorns with Cotyledon Discoloration

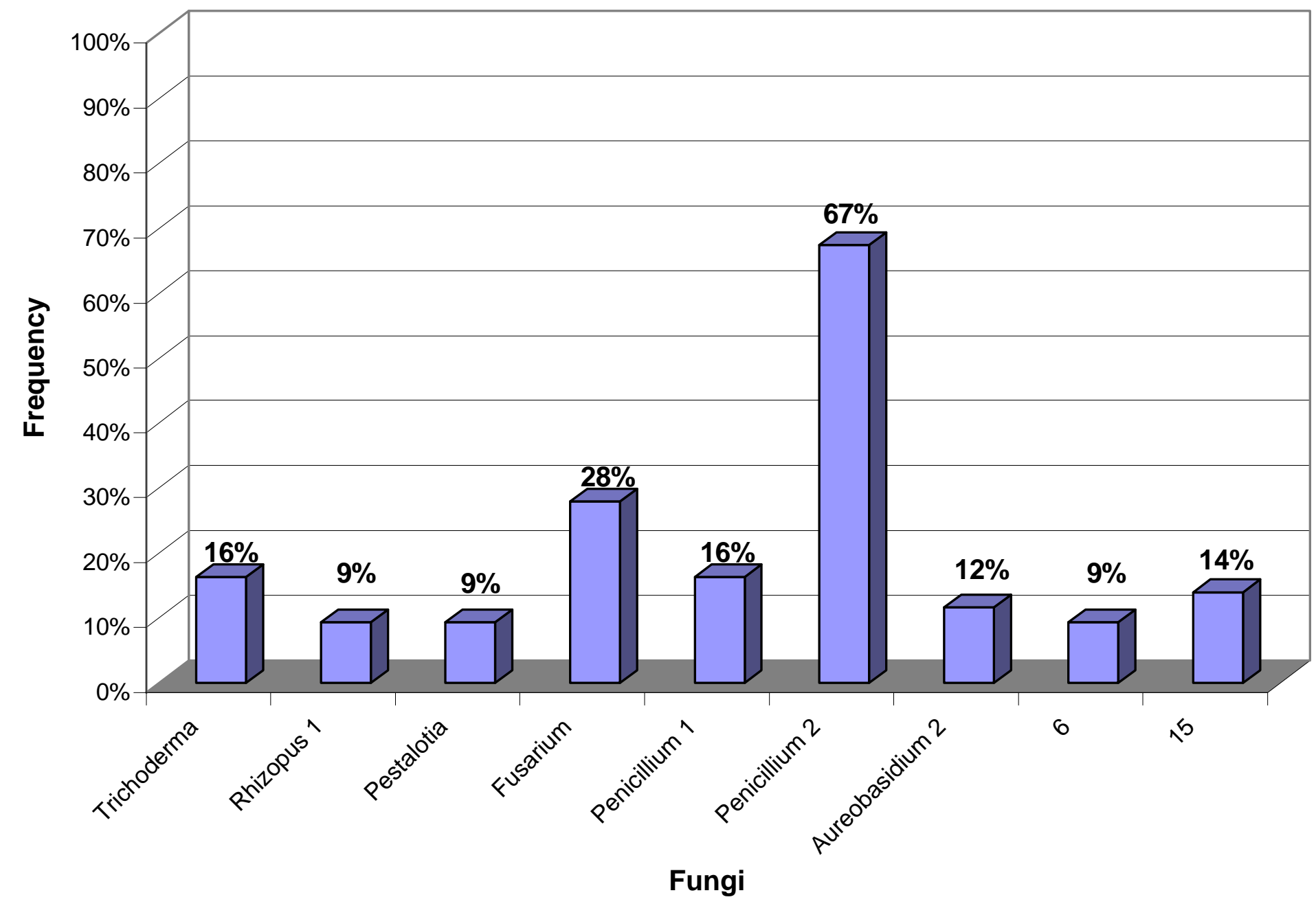


Figure C.2: Frequency of Fungi Isolated March-Harvested Acorns with Cotyledon Discoloration

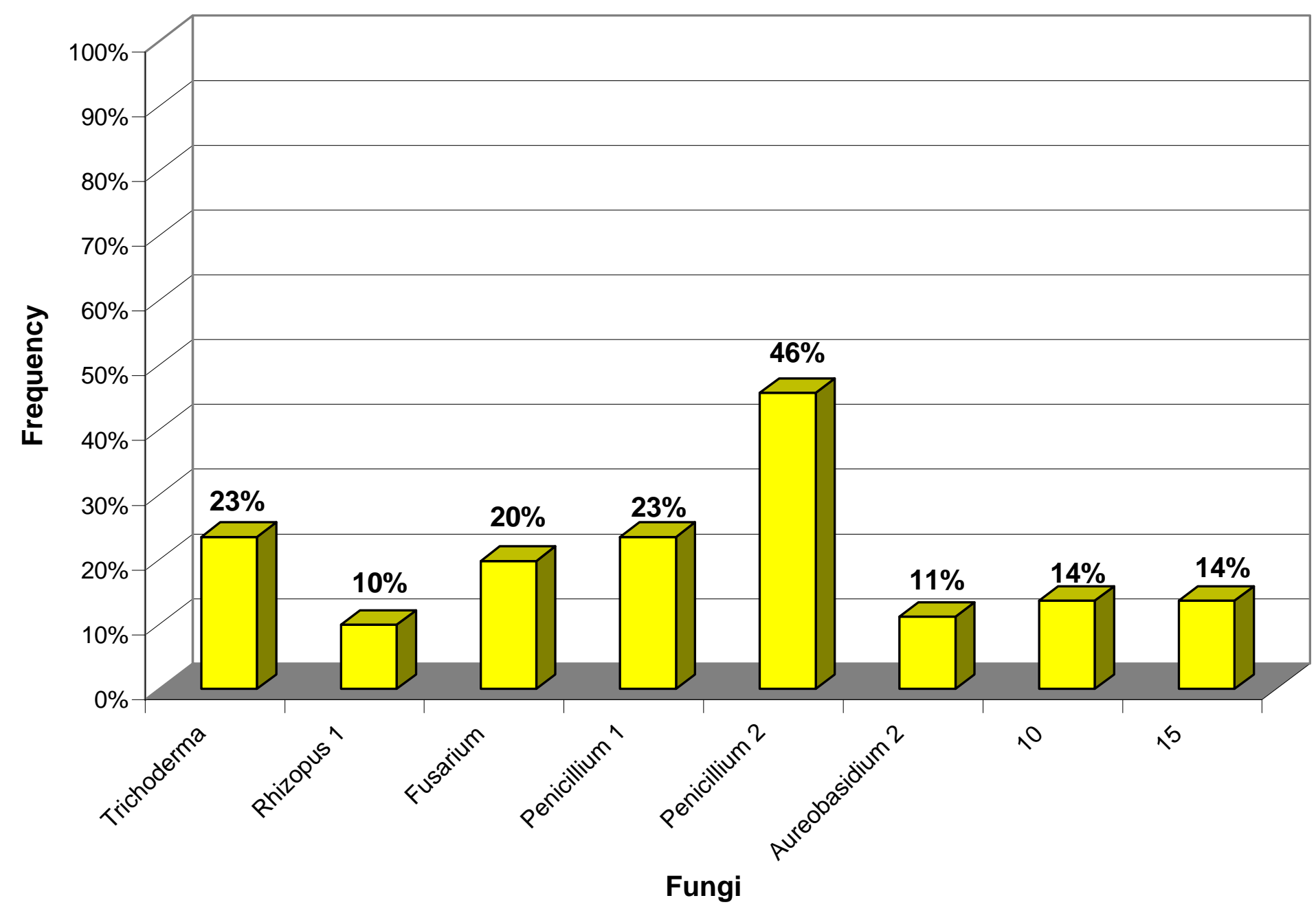


Figure C.3: Frequency of Fungi Isolated June-Harvested Acorns with Cotyledon Discoloration

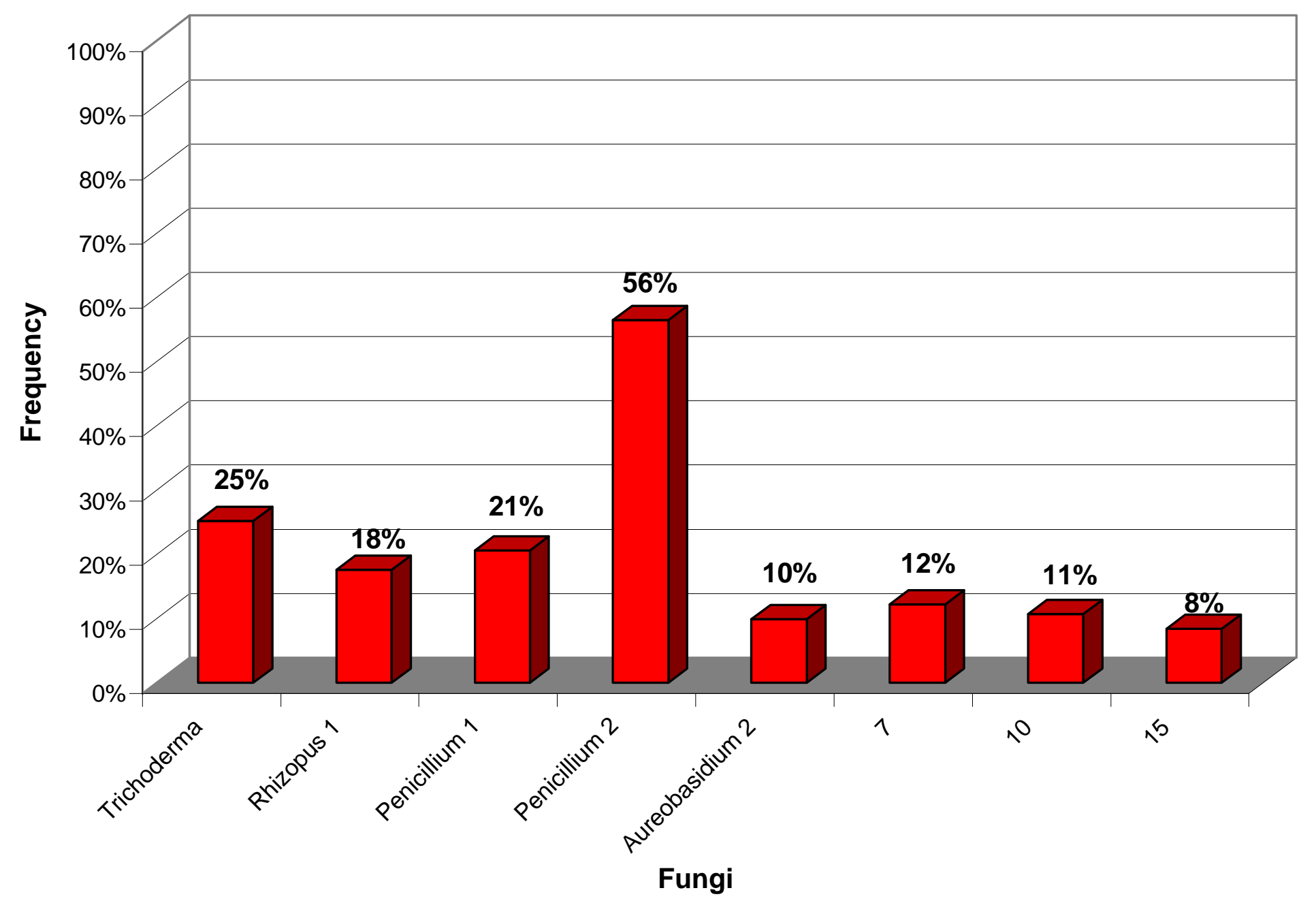


Figure C.4: Frequency of Fungi Isolated from Glade Run Acorns with Cotyledon Discoloration

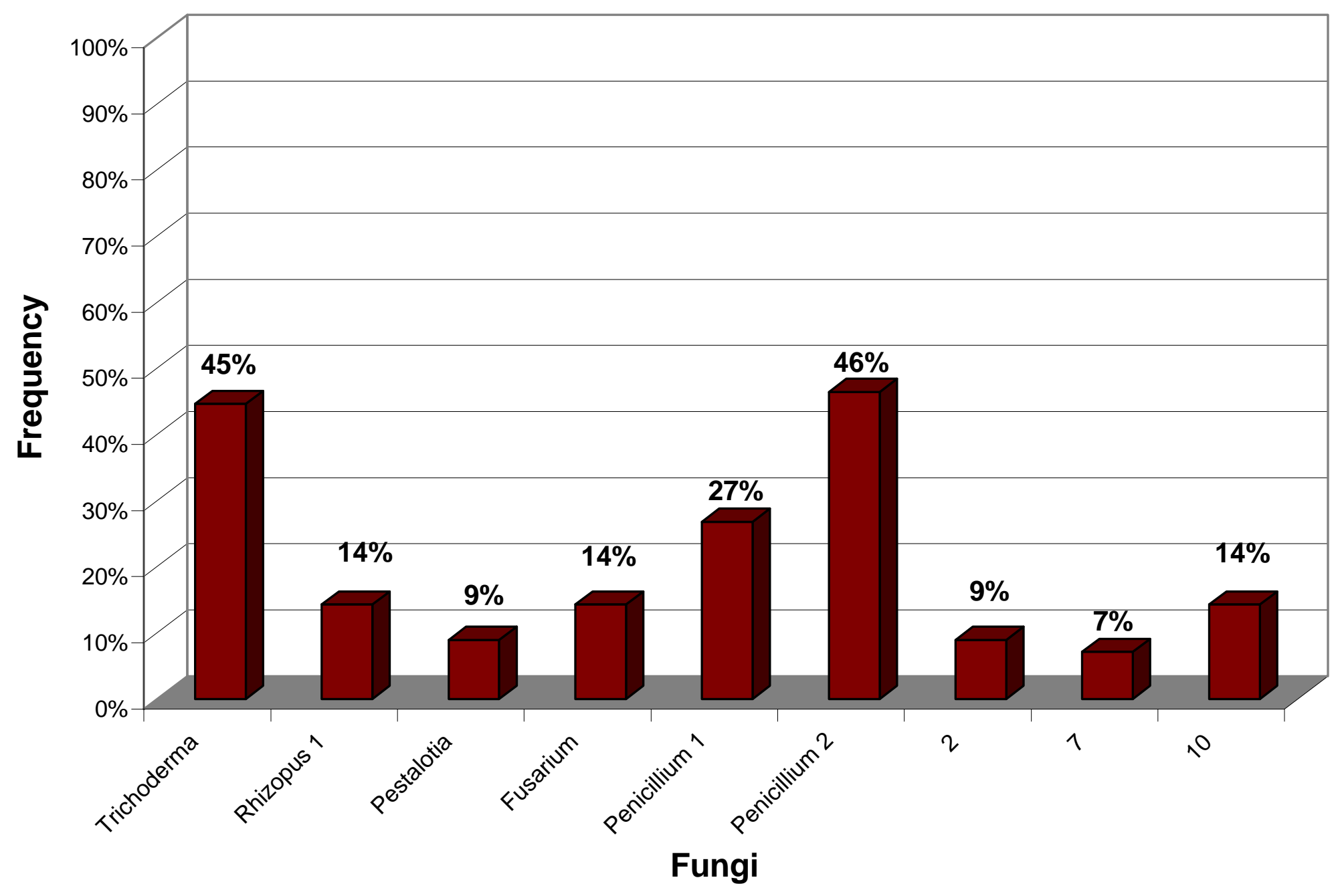


Figure C.5: Frequency of Fungi Isolated from Lick Run Acorns with Cotyledon Discoloration

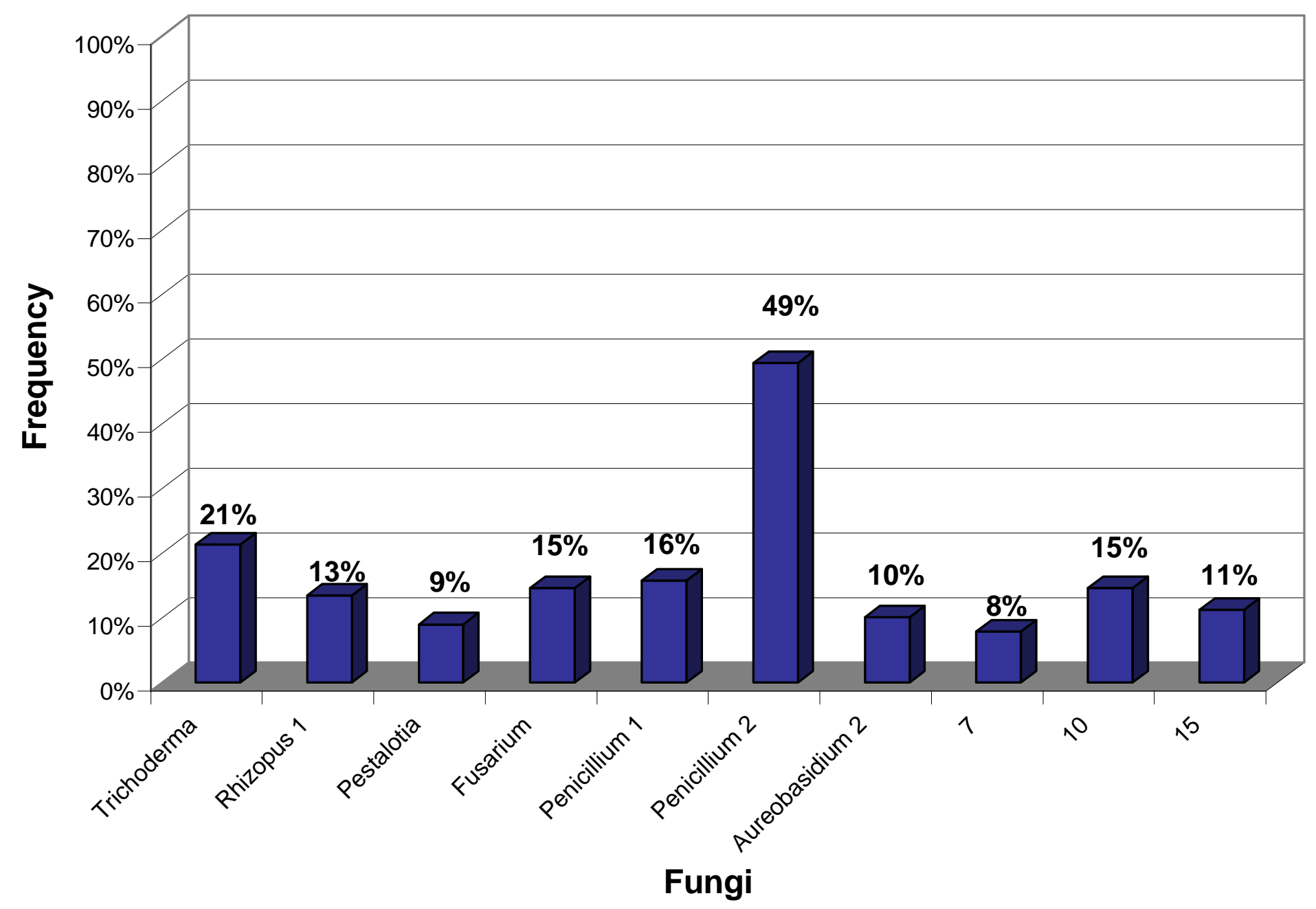


Figure C.6: Frequency of Fungi Isolated from Laurel Run Acorns with Cotyledon Discoloration

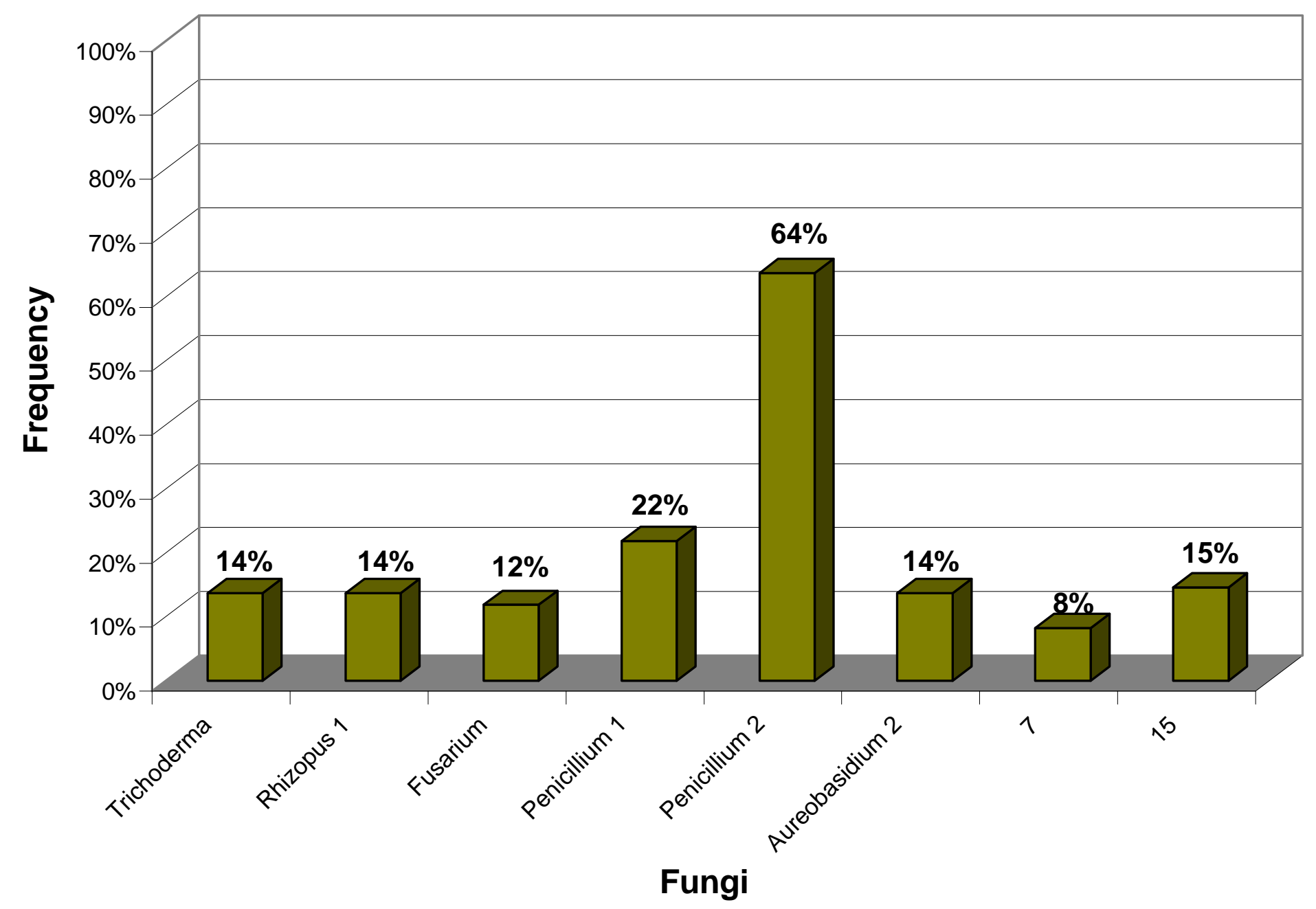


Figure C.7: Frequency of Fungi Isolated From Glade Run Acorns with Cotyledon Discoloration Over Three Harvest Dates

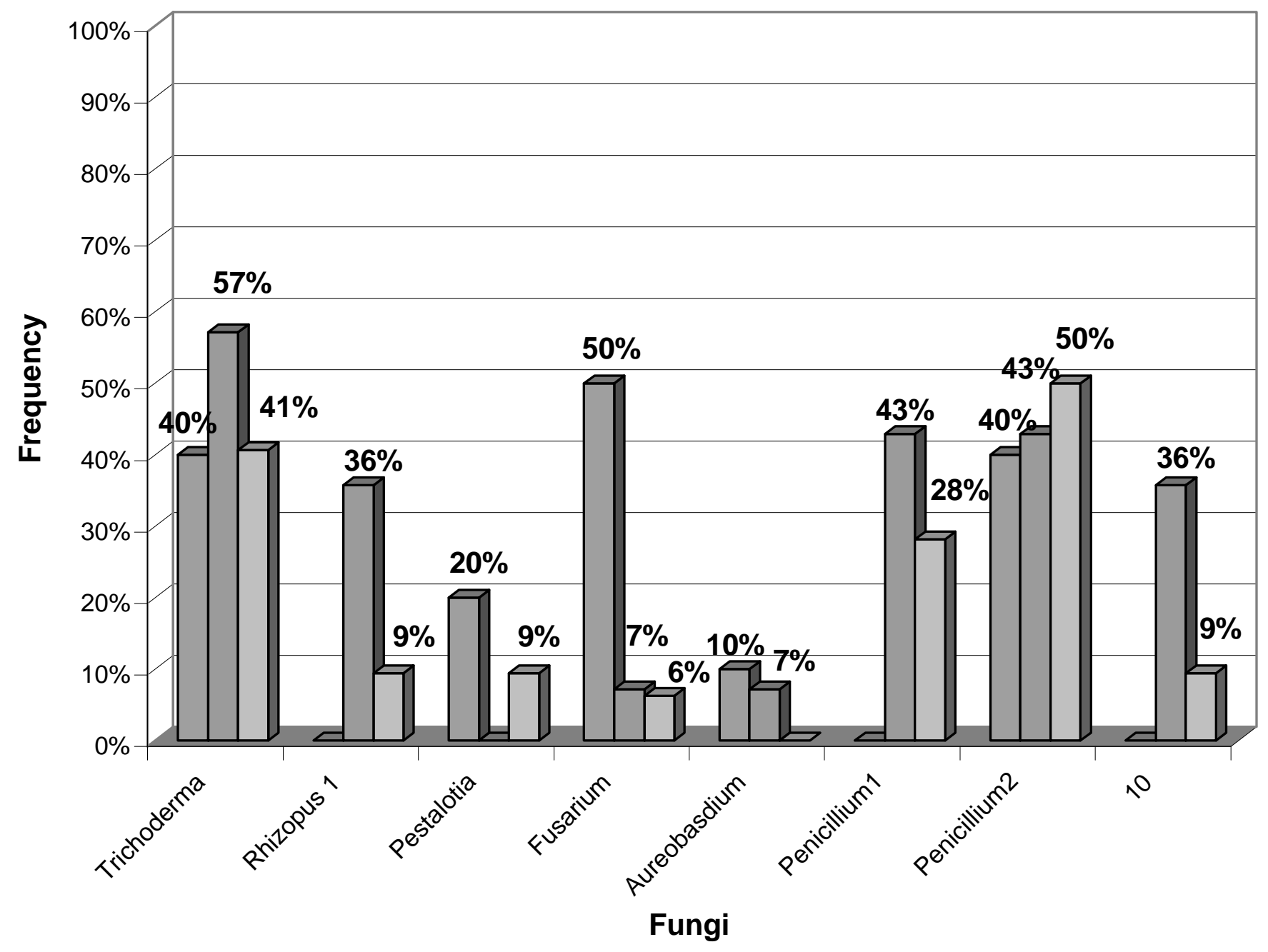


Figure C.8: Frequency of Fungi Isolated From Lick Run Acorns with Coytledon

Discoloration Over Three Harvest Dates

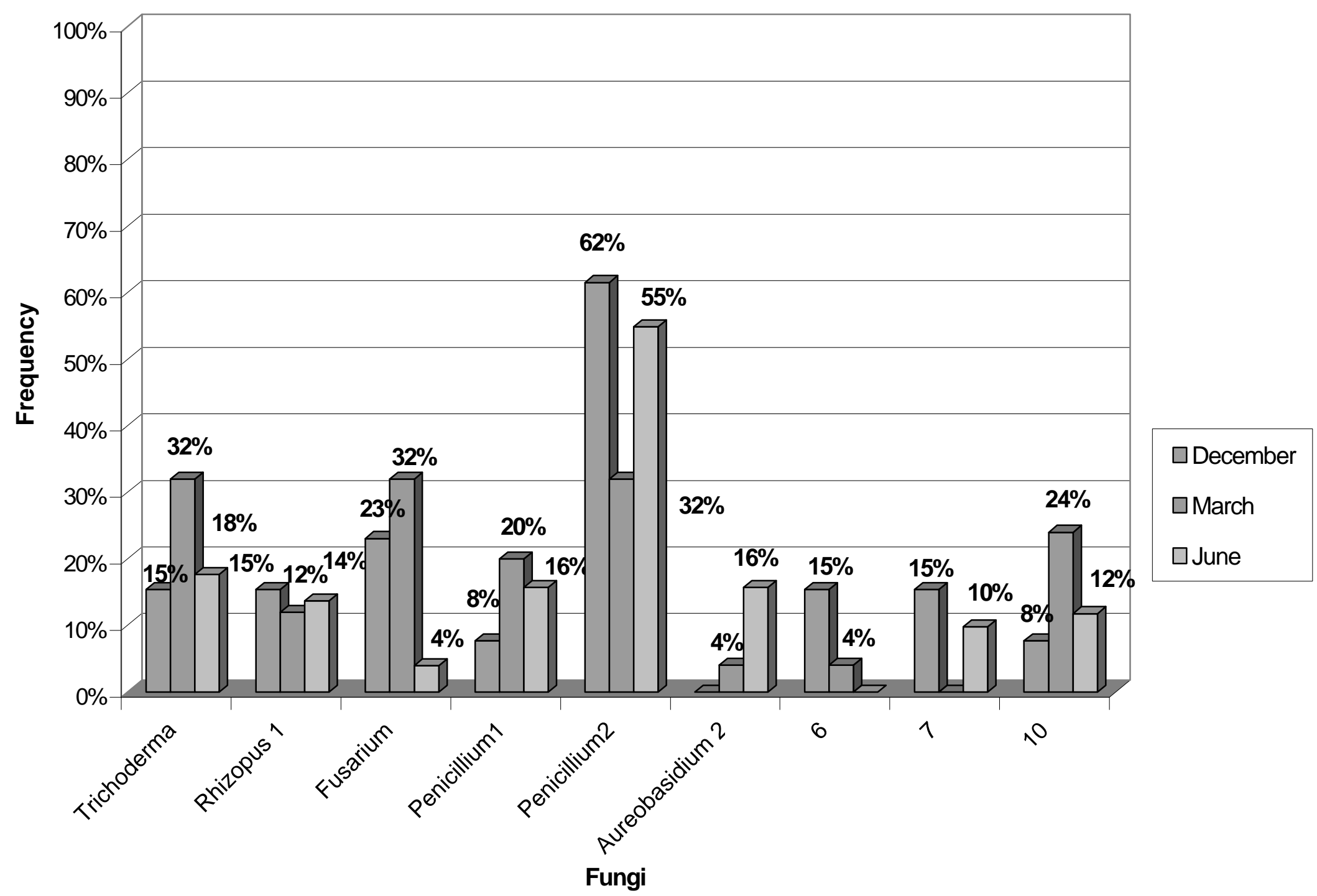


Figure C.9: Frequency of Fungi Isolated from Laurel Run Acorns with Cotyledon Discoloration Over Three Harvest Dates

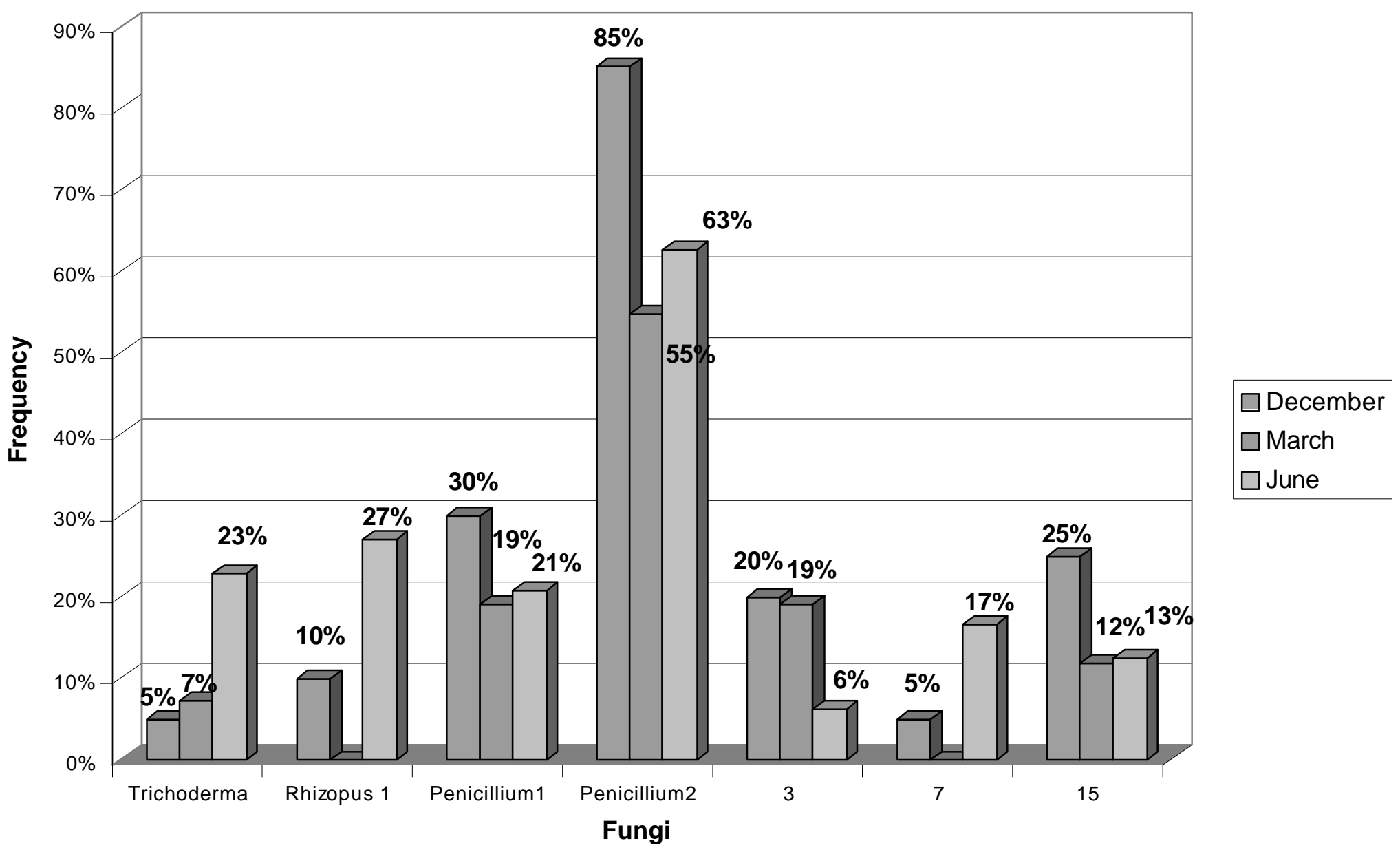




\section{Appendix D}

Figures: Frequency of Fungi Isolated by Site and Harvest Date for Acorns with Cotyledon Discoloration and Weevil Damage. 
Figure D.1: Frequency Fungi Isolated from March-Harvested Acorns with Cotyledon Discoloration and Weevil Damage

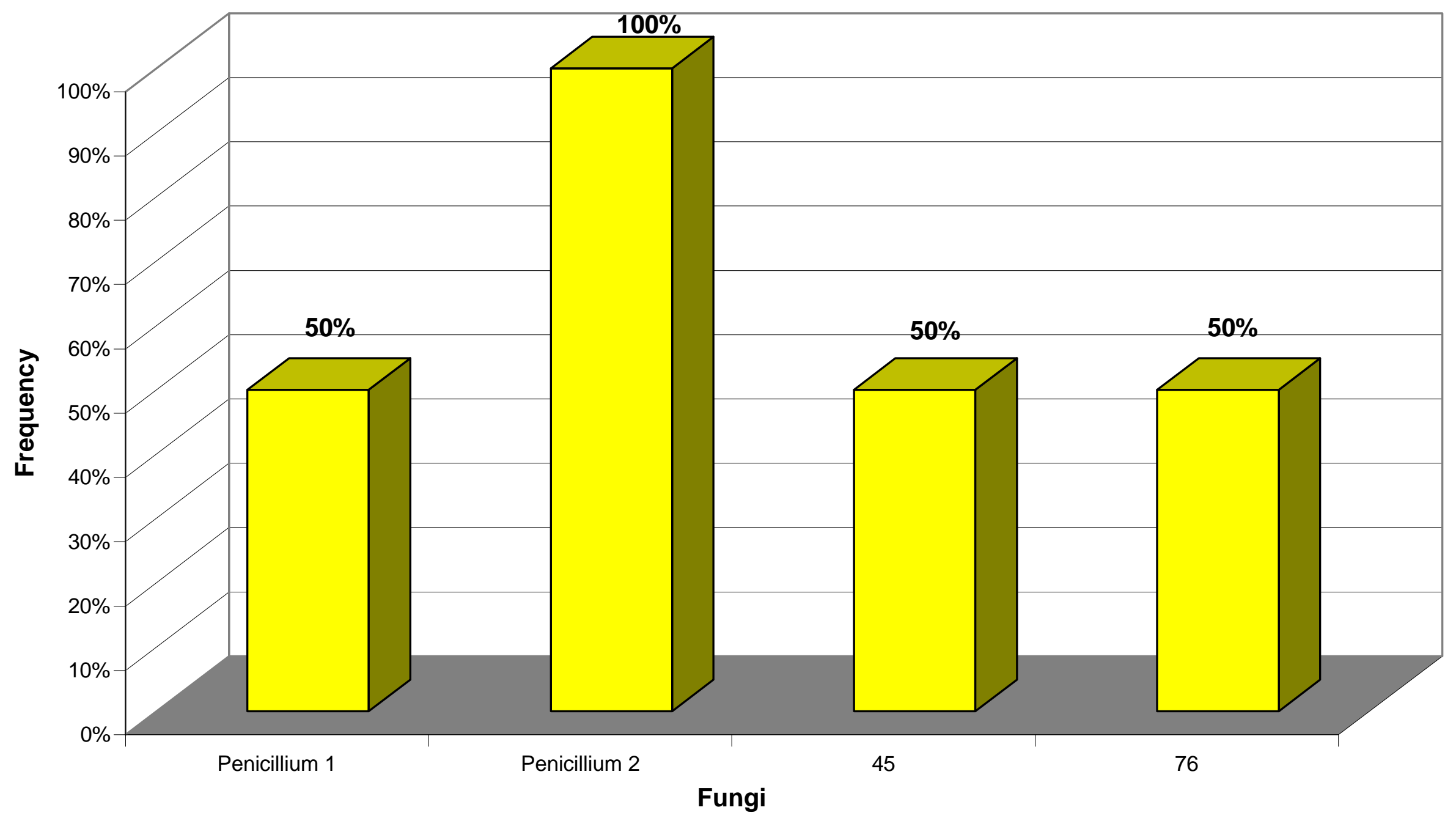


Figure D.2: Frequency Fungi Isolated from June-Harvested Acorns with Cotyledon Discoloration and Weevil Damage

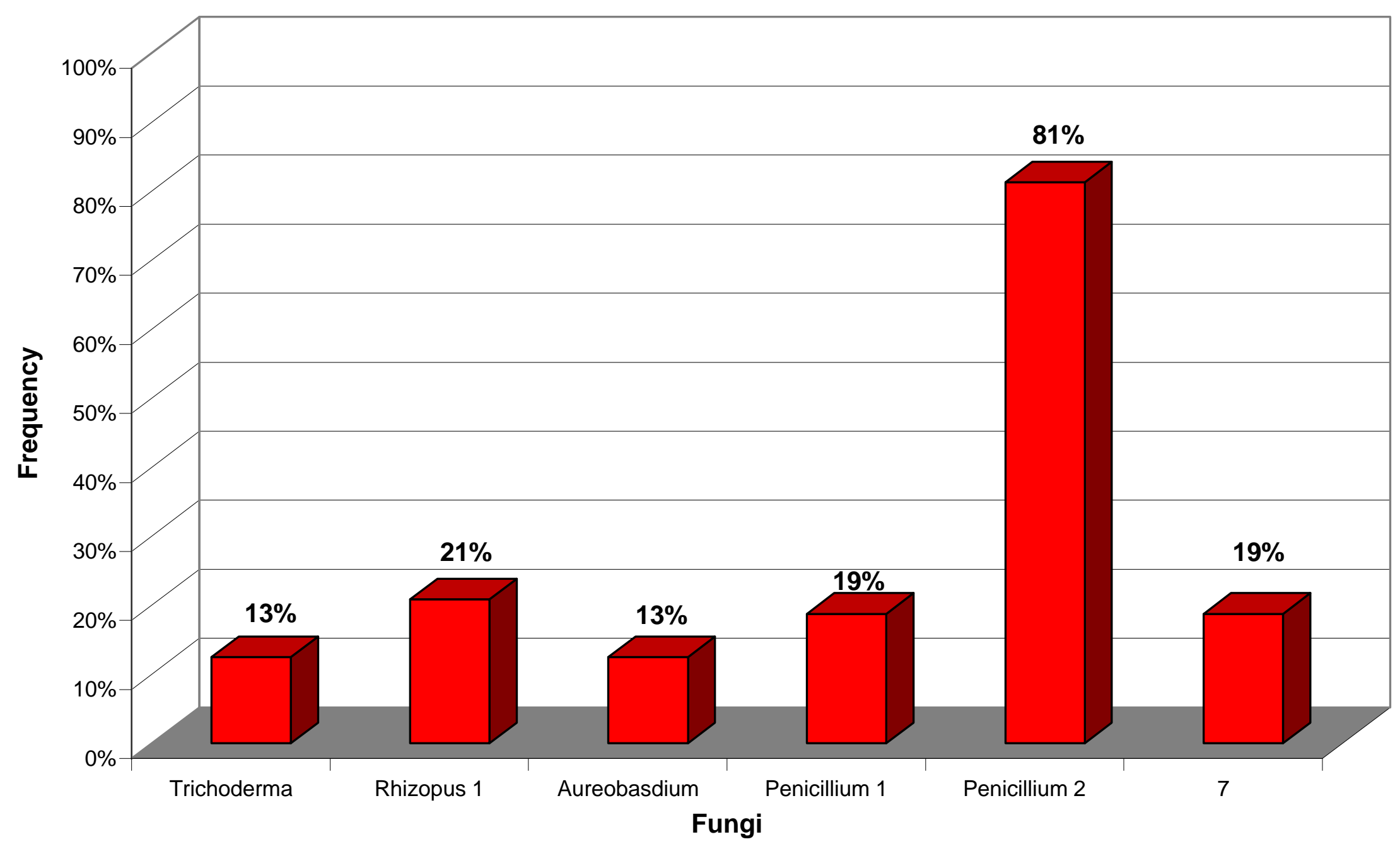


Figure D.3: Frequency of Fungi Isolated From June-Harvested Acorns with Cotyledon Disocloration and Weevil Damage by Site

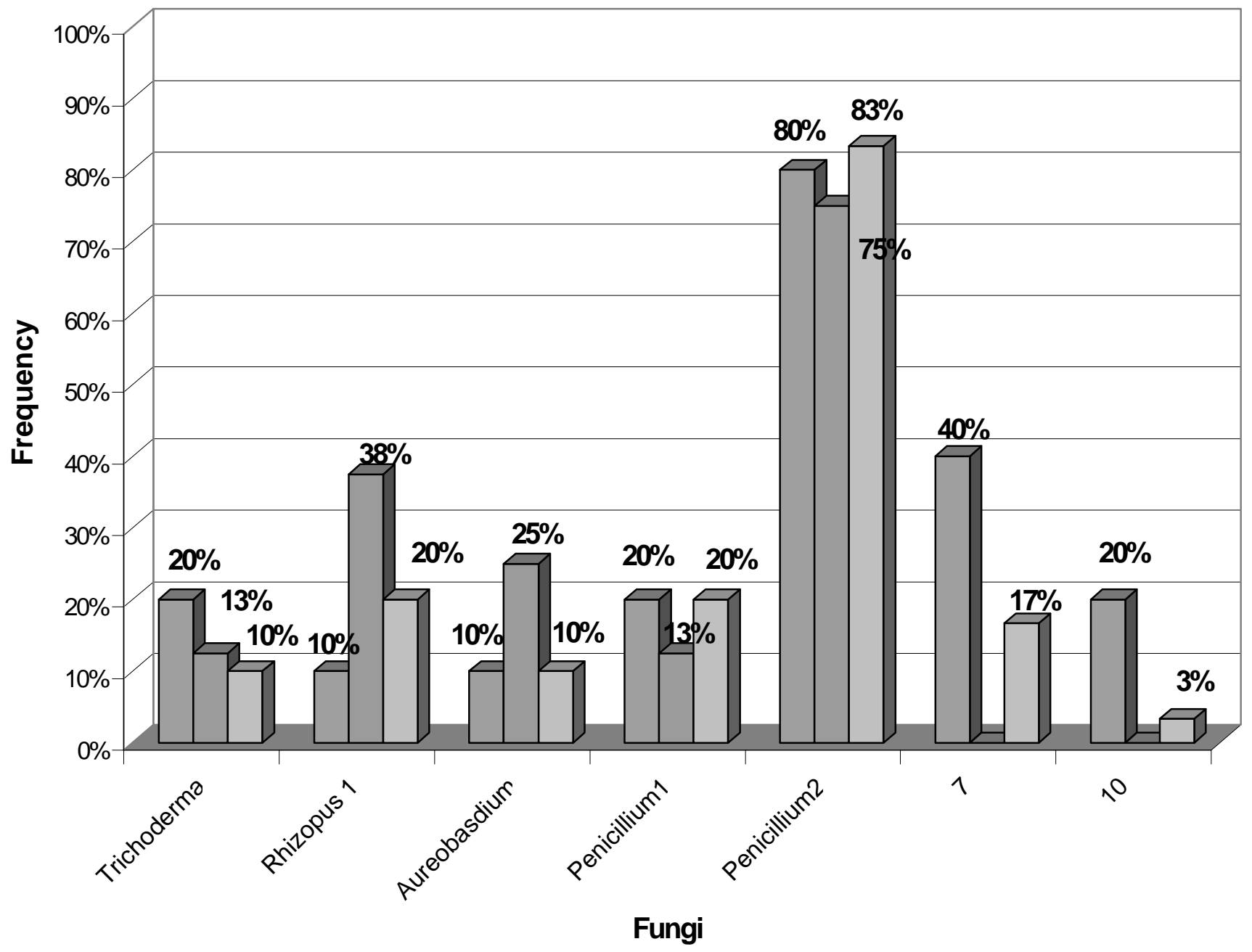


Appendix E

Figures: Frequency of Fungi Isolated by Site and Harvest Date for Acorns with Weevil Damage 
Figure E.1. Frequency of Fungi Isolated from December-Harvested Acorns with Weevil Damage

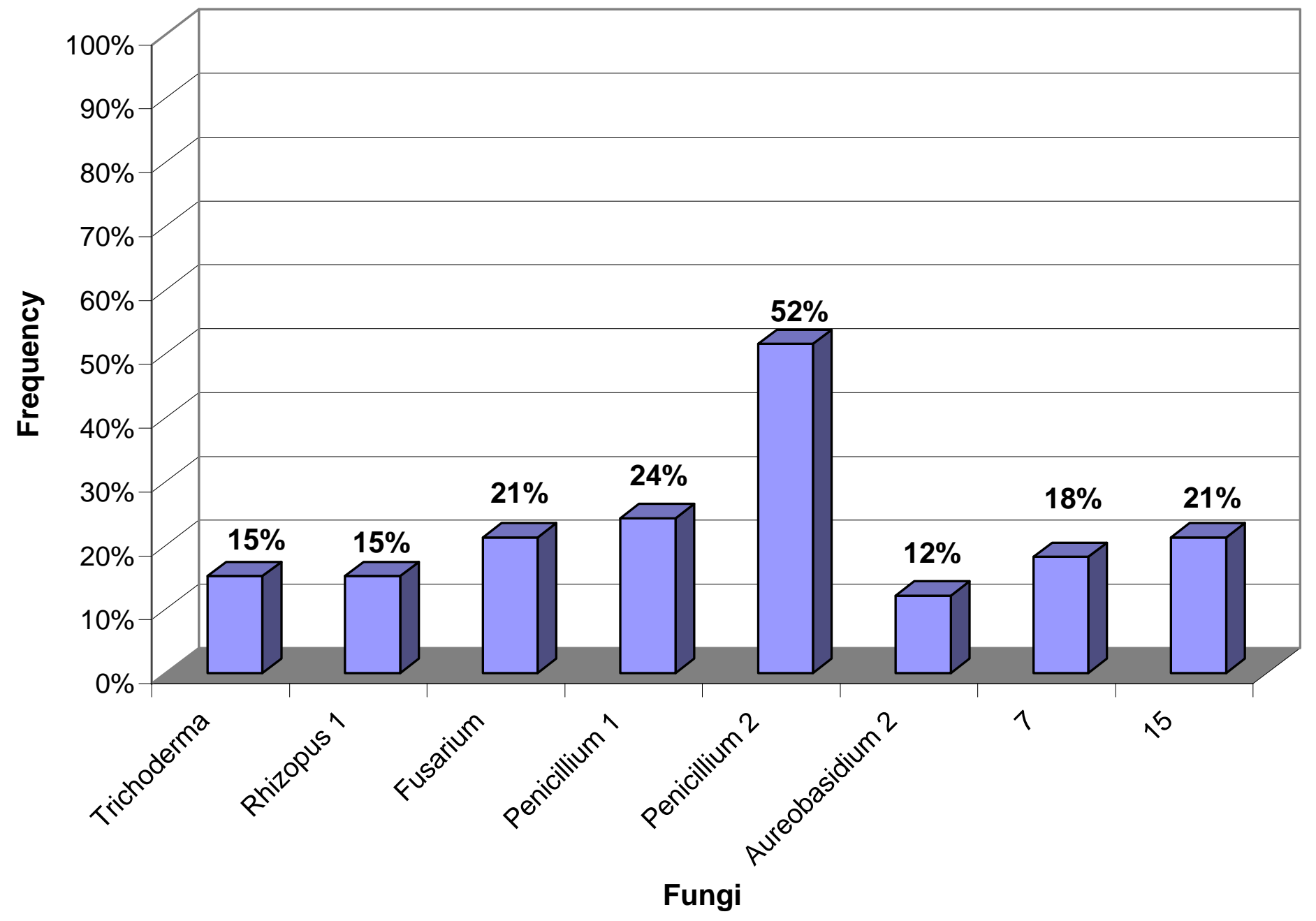


Figure E.2. Frequency of Fungi Isolated from March-Harvested Acorns with Weevil Damage

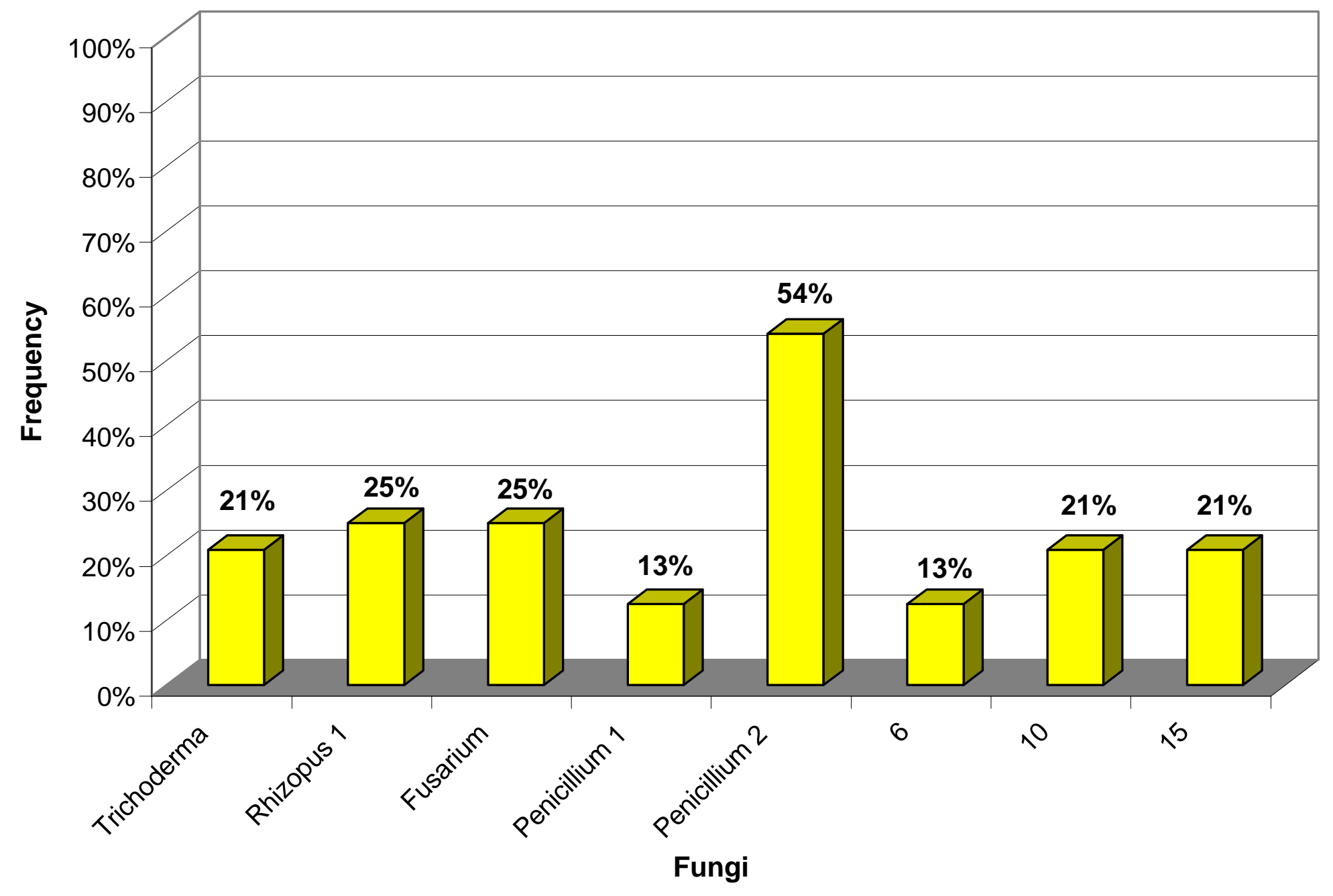


Figure E. 3. Frequency of Fungi Isolated from June-Harvested Acorns with Weevil Damage

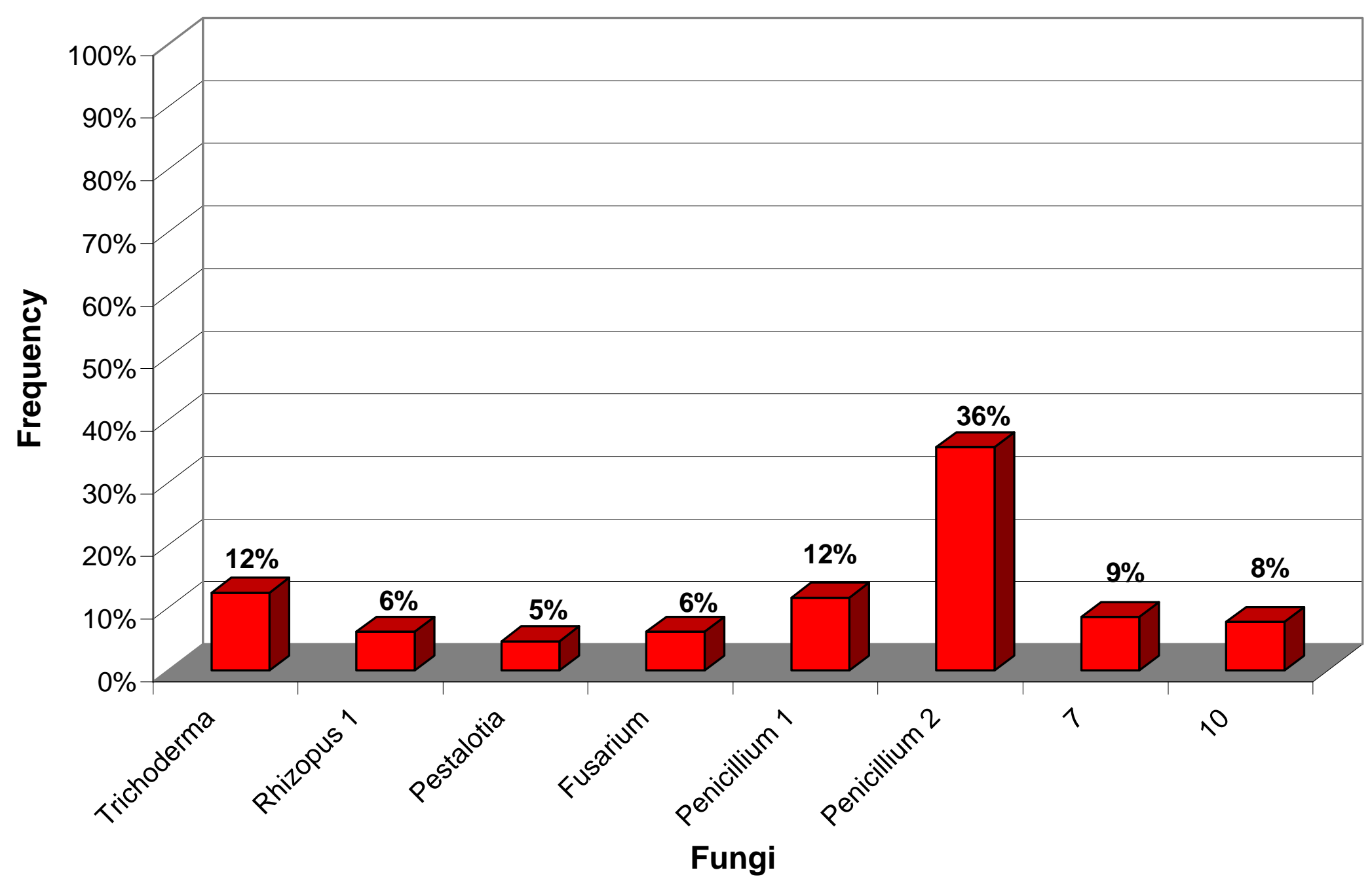


Figure E.4. Frequency of Fungi Isolated From Glade Run Acorns with Weevil Damage

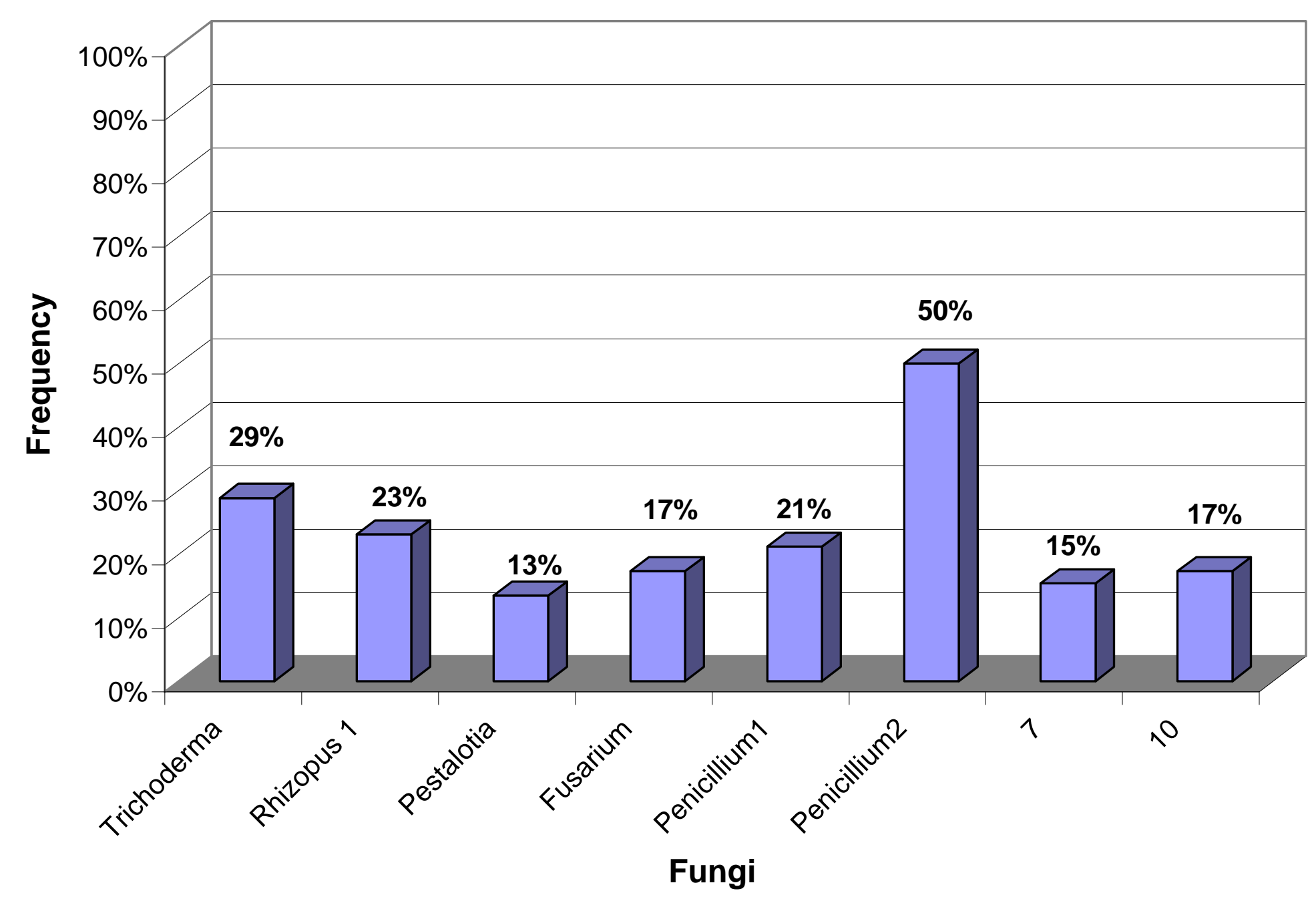


Figurre E.5. Frequency of Fungi Isolated From Lick Run Acorns with Weevil Damage

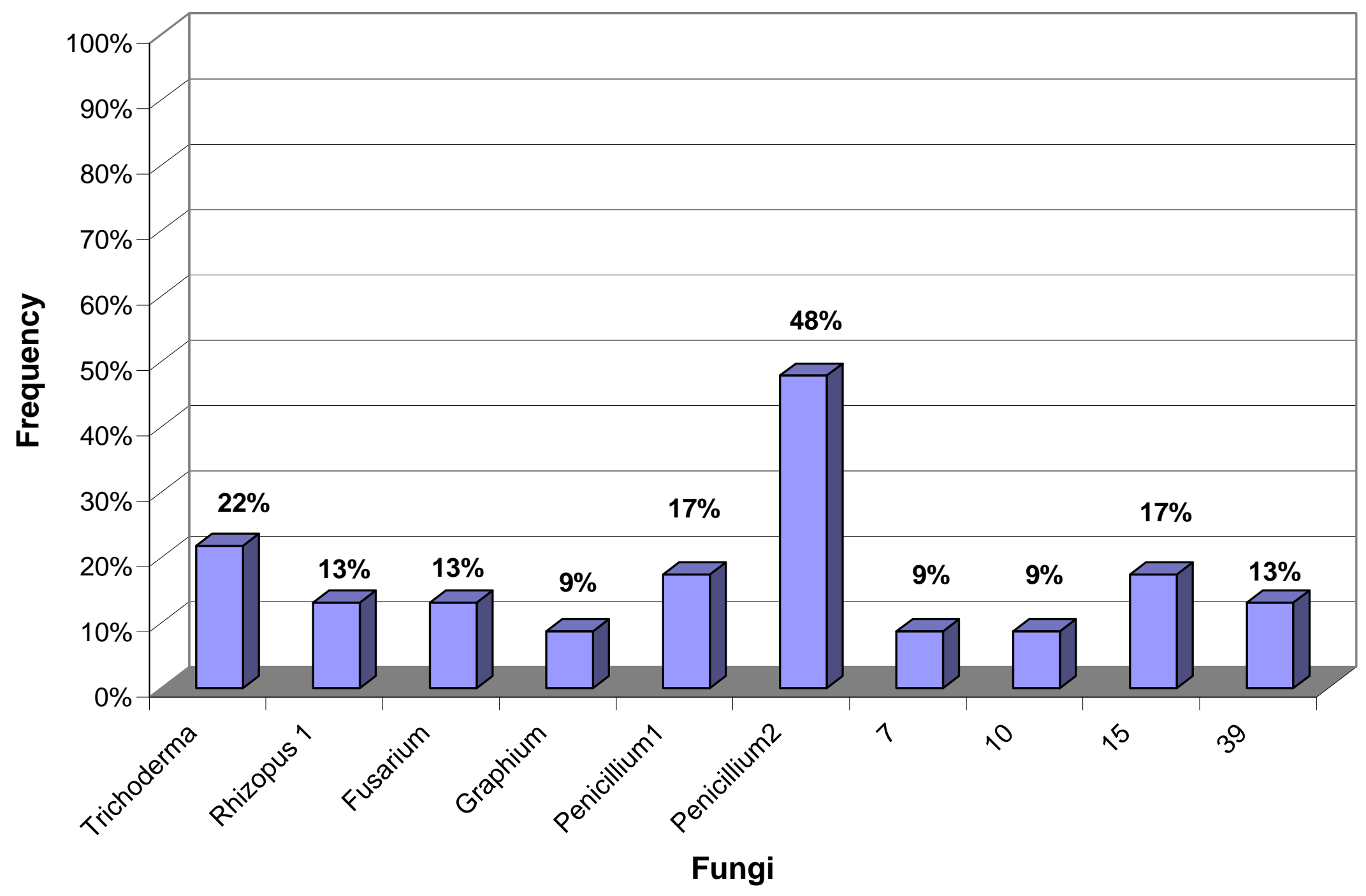


Figure E.6. Frequency of Fungi Isolated From Laurel Run Acorns with Weevil Damage

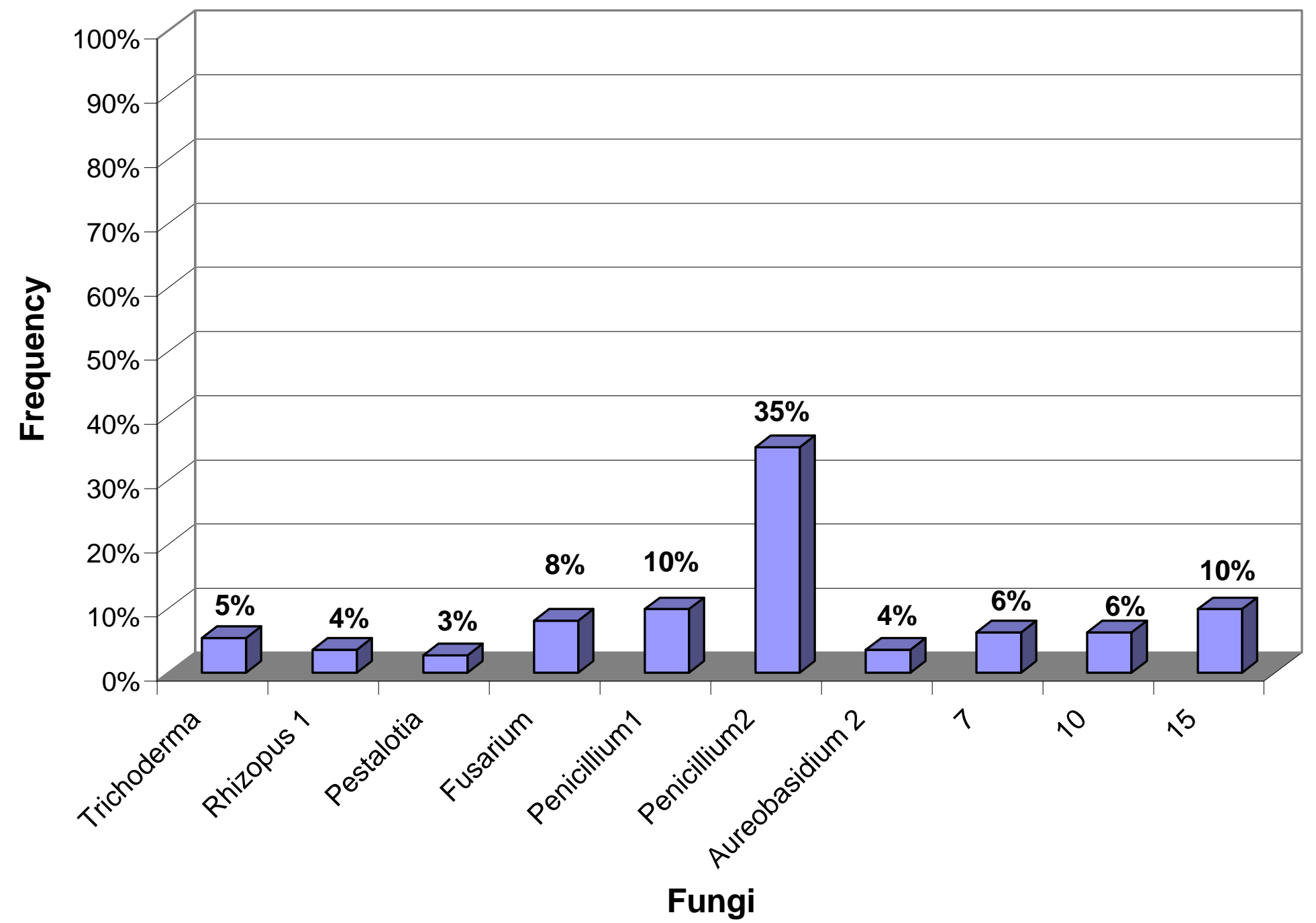


Figure E.7. Frequency of Fungi Isolated From Glade Run Acorns with Weevil Damage by Harvest Date

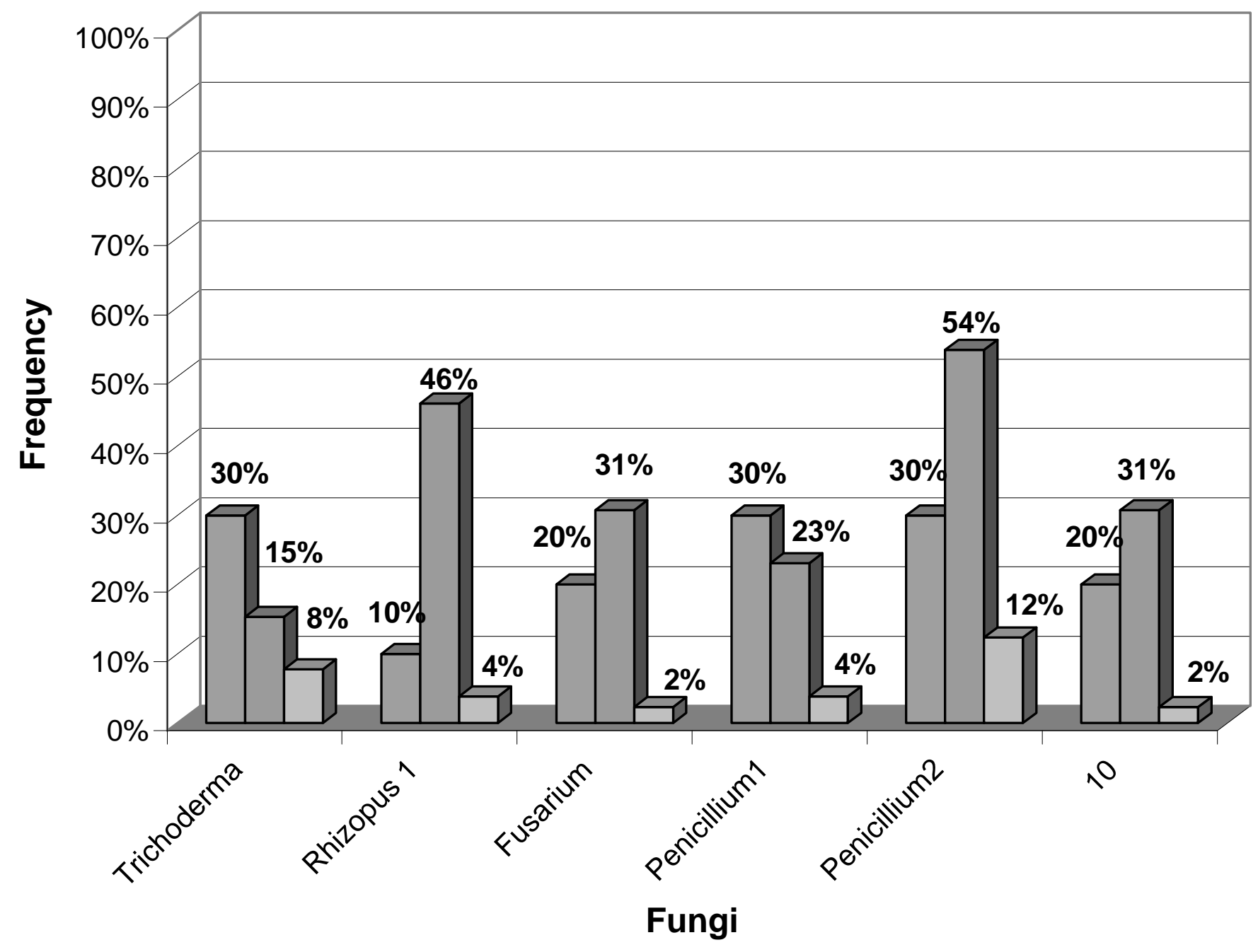


Figure E.8. Frequency of Fungi Isolated From Lick Run Acorns with Weevil Damage by Harvest Date

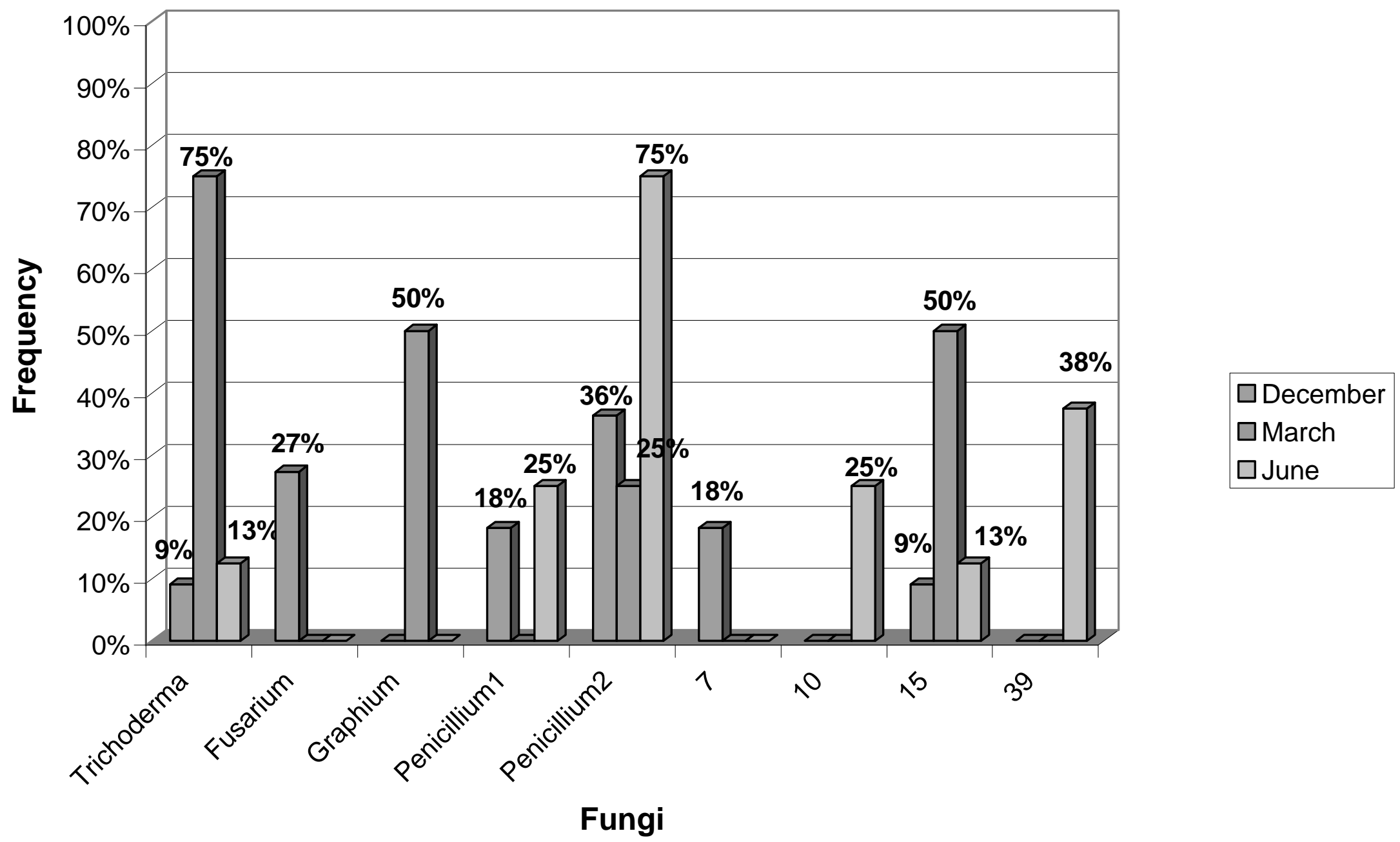


Figure E.9. Frequency of Fungi Isolated From Laurel Run Acorns with Weevil Damage by Harvest Date

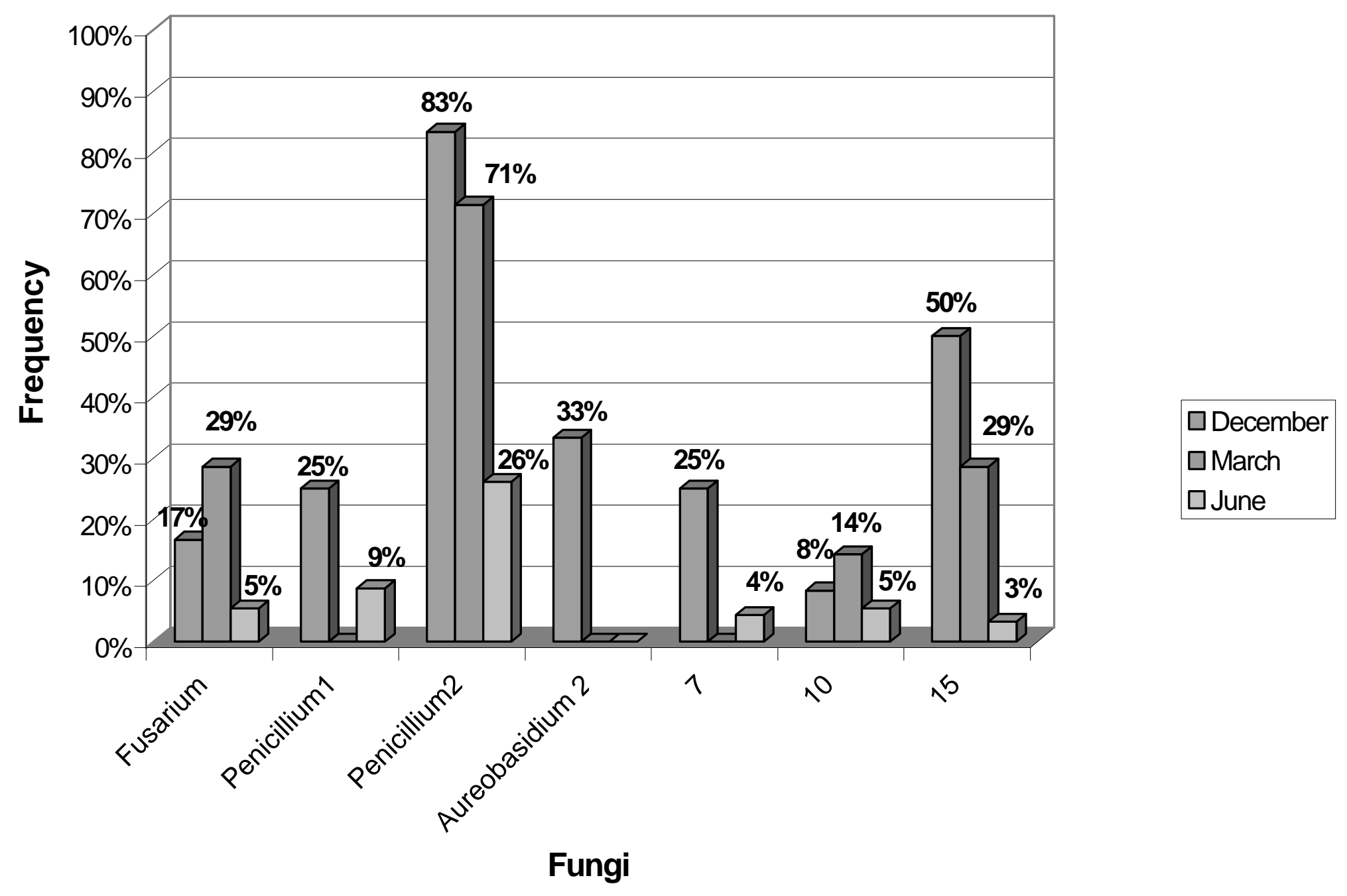




\section{Appendix F}

Table of Unknown Fungi's Morphological Characteristics 
Table F.1. Morphological characteristics of unknown fungi.

\begin{tabular}{|l|c|c|c|c|}
\hline \multicolumn{5}{|c|}{ Morphological Characteristics of Unknown Fungi } \\
\hline Fungi & Growth & Mycelium Color & Spores & Colonies \\
\hline Unknown 2 & Moderate & Gray & Single celled/Round/Gray & Compact \\
\hline Unknown 7 & Fast & White & Single celled/Round/Hyaline & Airy \\
\hline Unknown 10 & Slow & White & Single celled/Round/Hyaline & Airy \\
\hline Unknown 15 & Slow & White & NA & Compact \\
\hline Unknown 18 & Moderate & Pink/Yellow/White & Single celled/Round/Hyaline & Compact \\
\hline Unknown 19 & Slow & Light Yellow & Single celled/Round/Dark & Compact \\
\hline Unknown 39 & Moderate & Gray/Pink & Single celled/Oblong/Gray & Compact \\
\hline
\end{tabular}


Appendix G

Pictures of Fungi 
Figure G.1 Penicillium sp. 1 on PDA

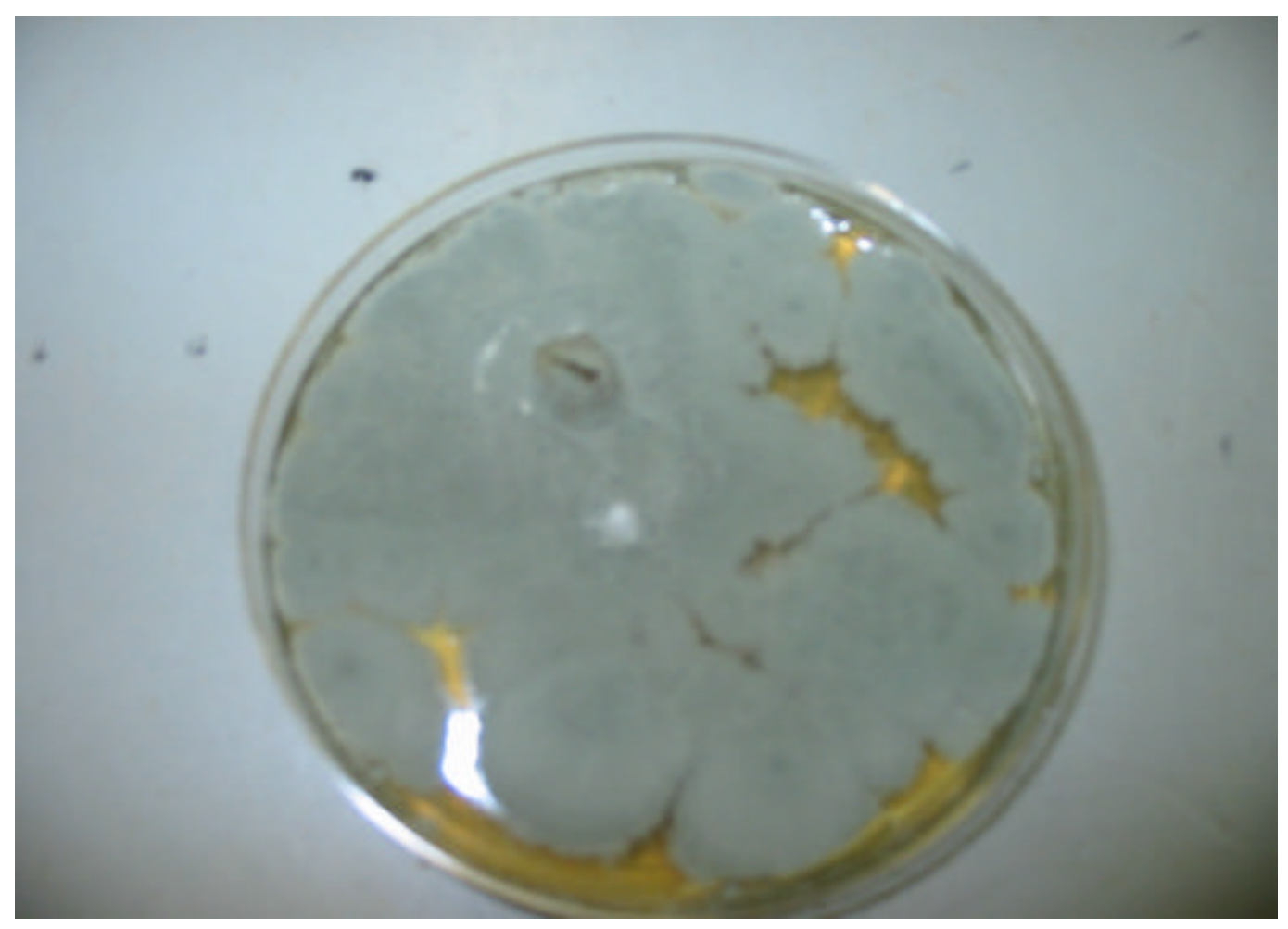

Figure G.2 Penicillium sp. 2 on PDA

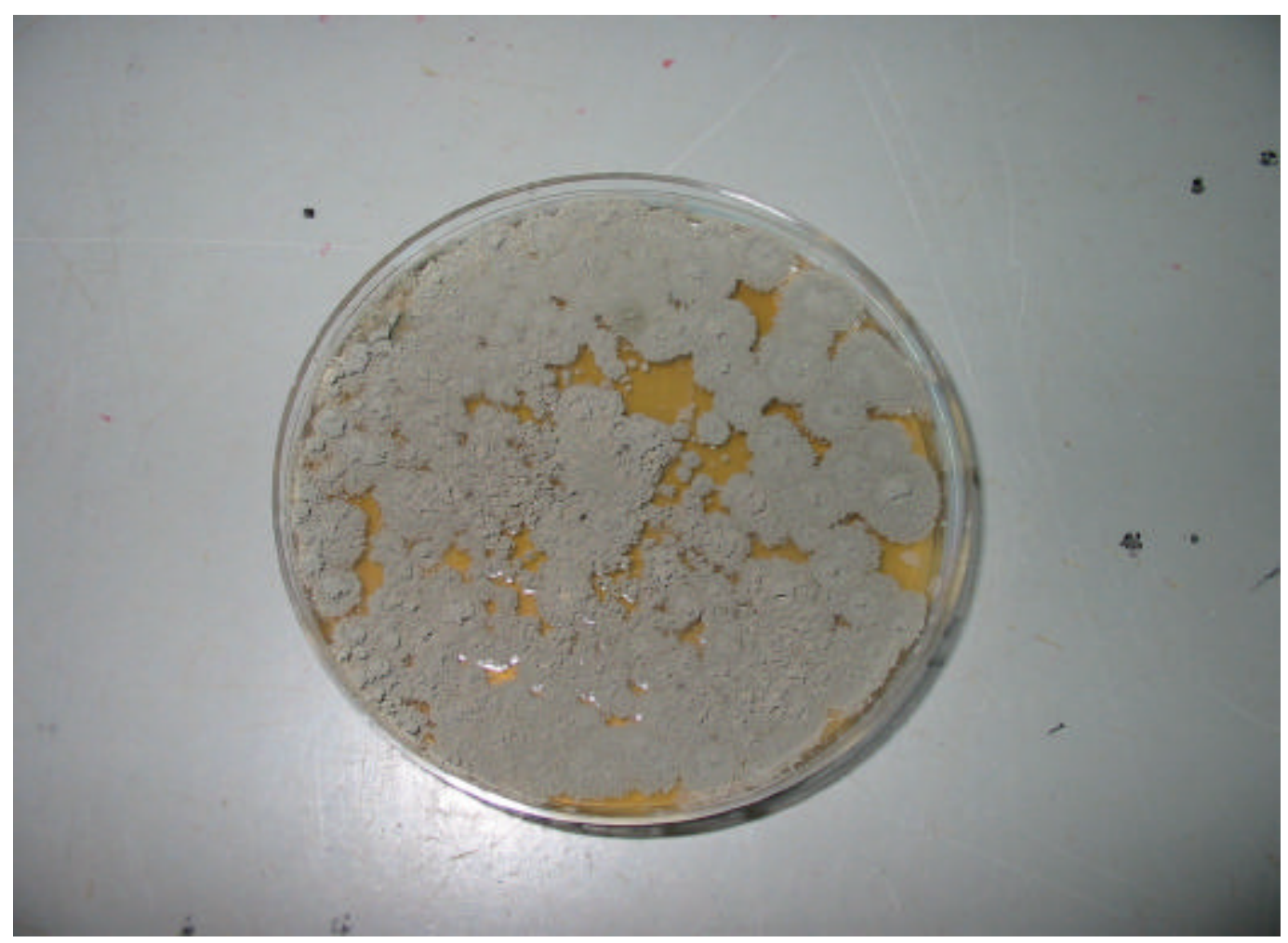


Figure G.3 Penicillium sp. 1 and 2 (From left to right) on Czapeck Agar

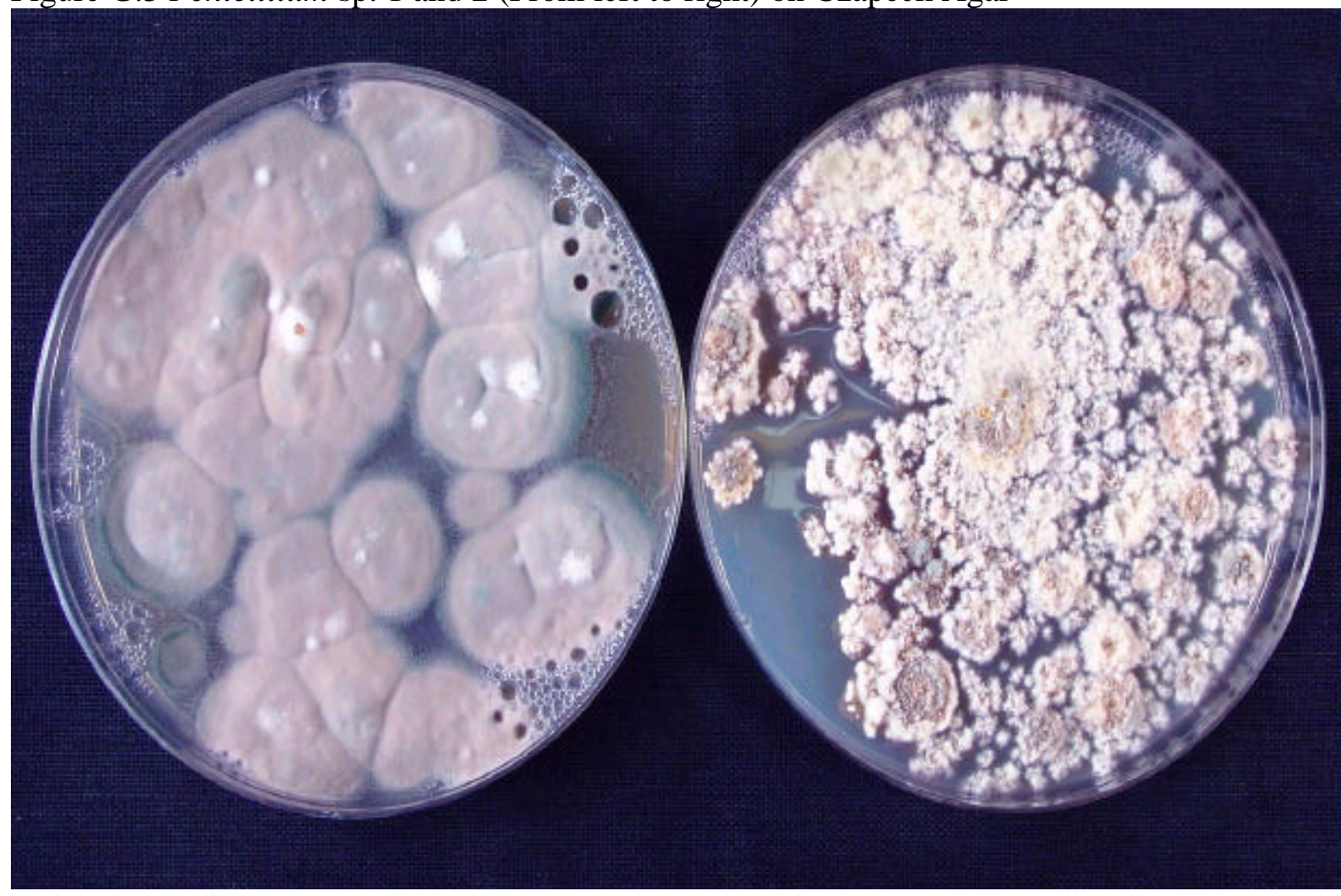

Figure G.4 Trichoderma sp. on PDA

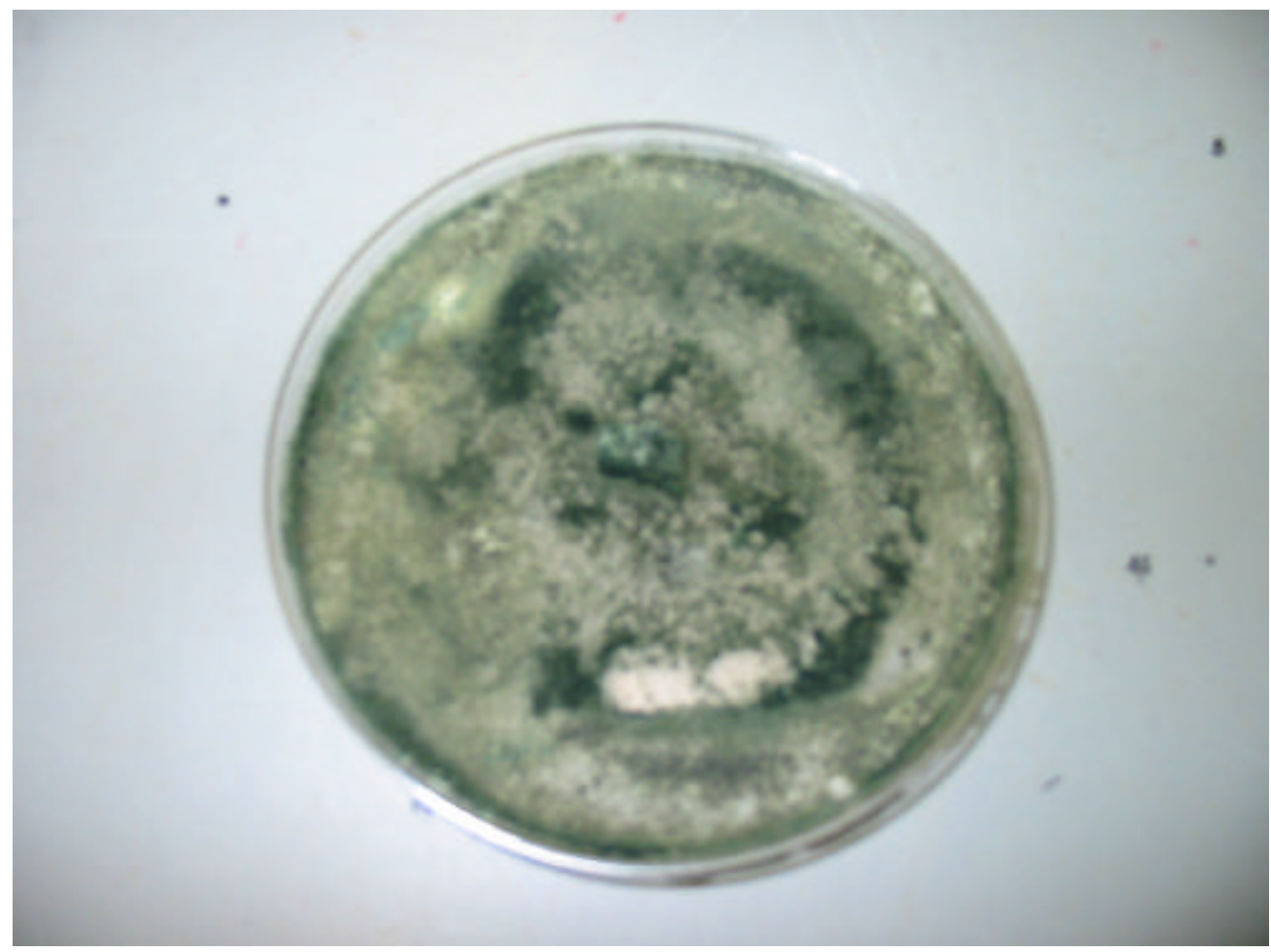


Figure G.5 Fusarium sp. on PDA

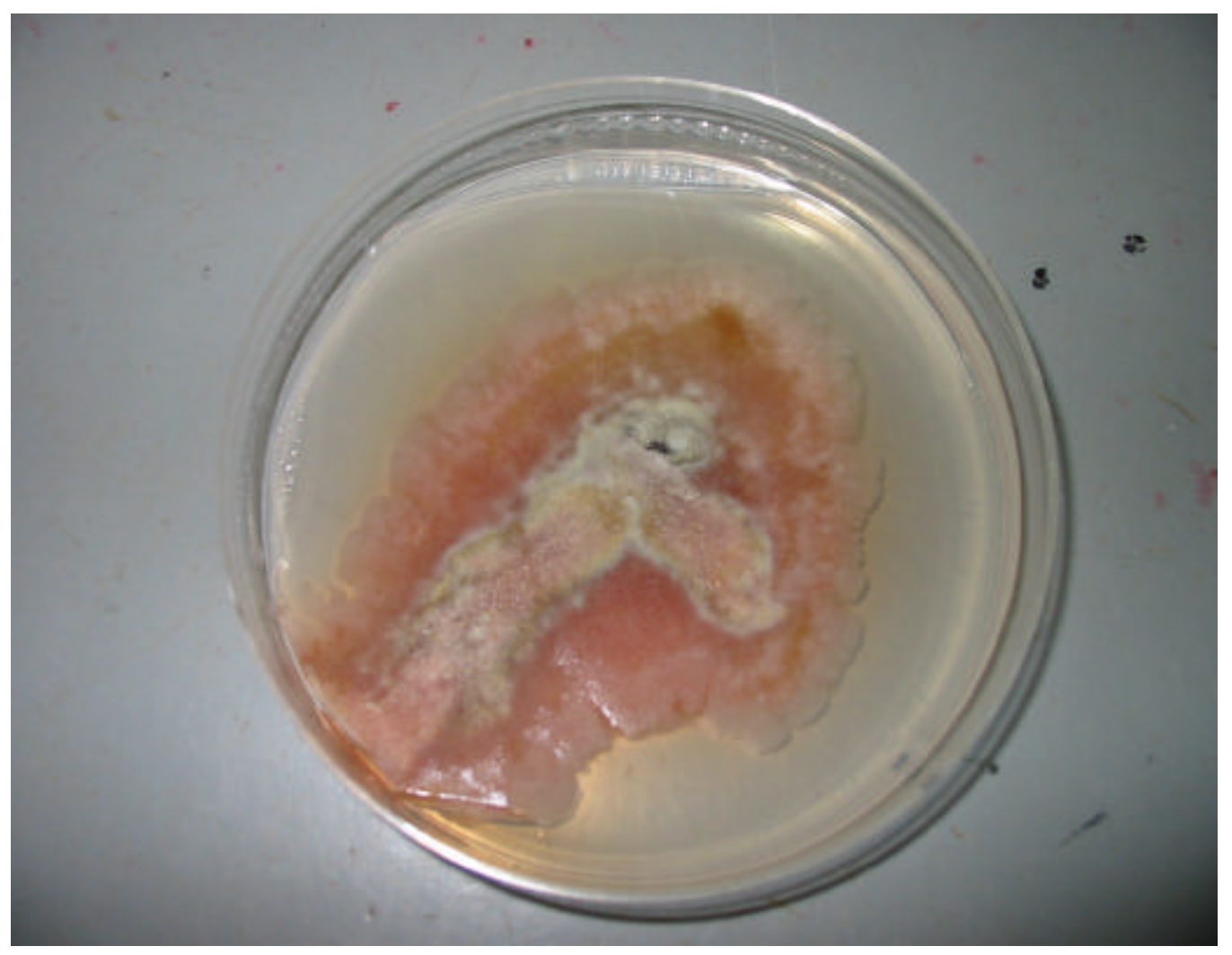

Figure G.6 Rhizopus sp. 1 on PDA

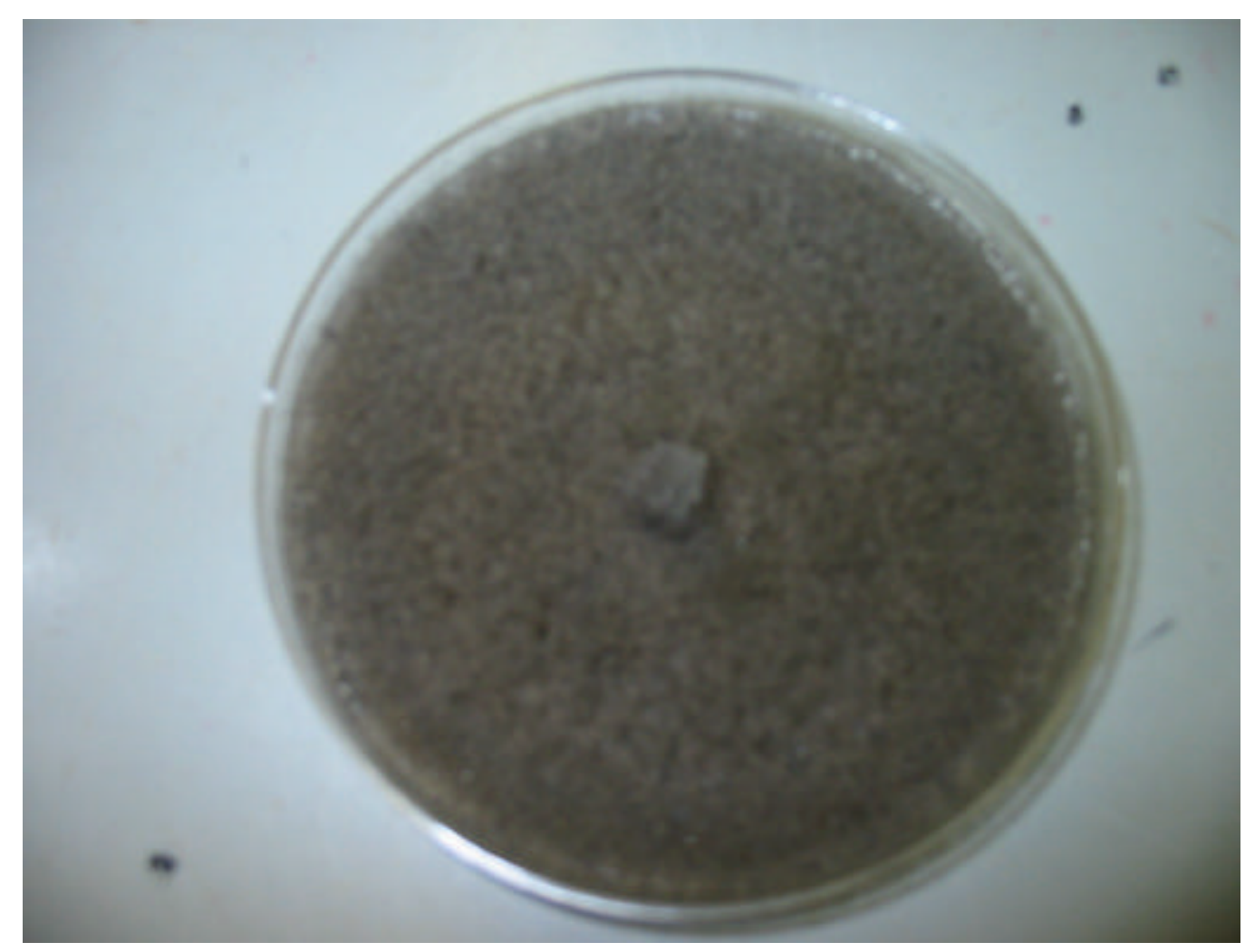


Figure G.7 Penicillium sp. 3 on PDA

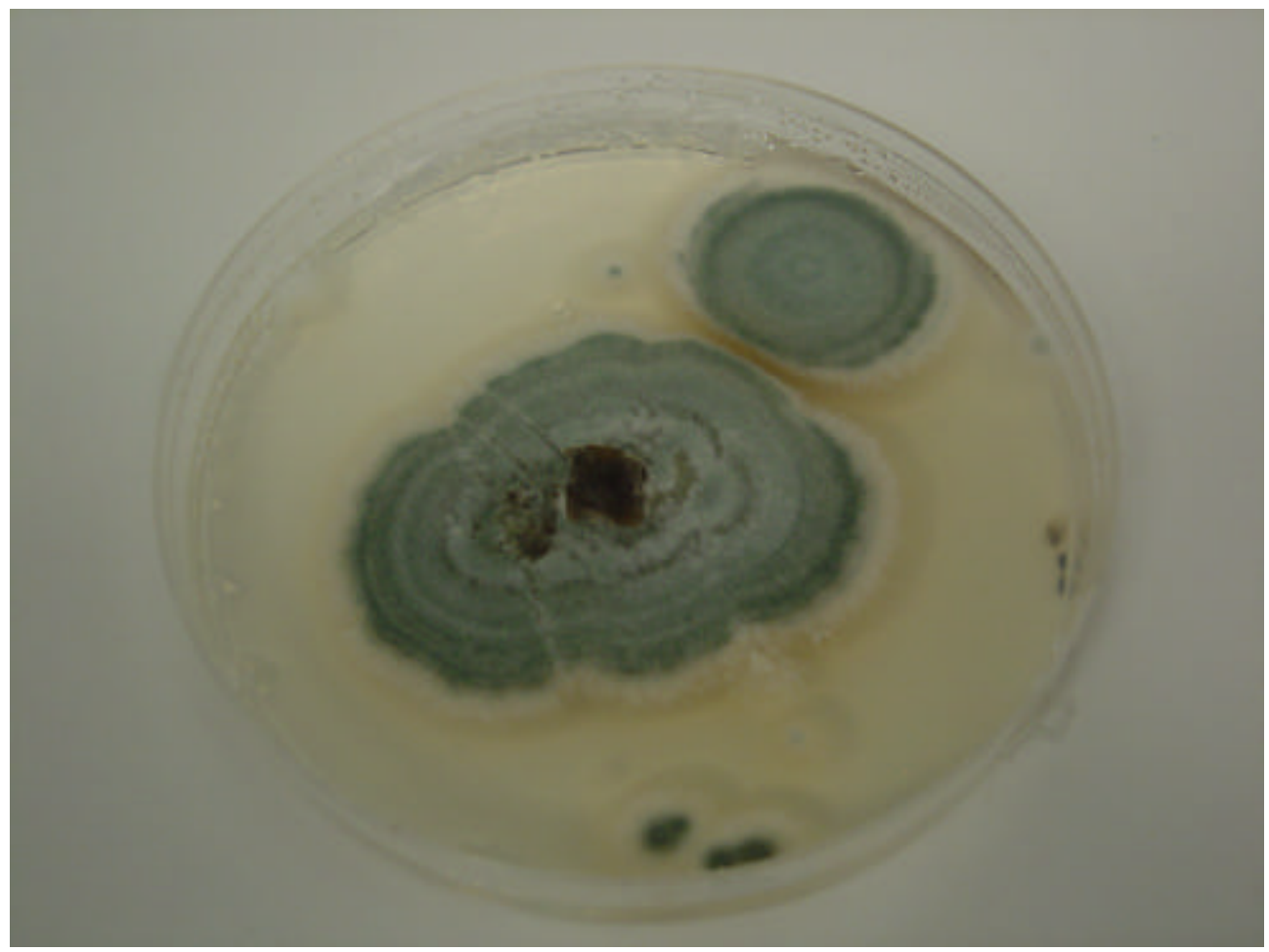

Figure G.8 Unknown 2 on PDA

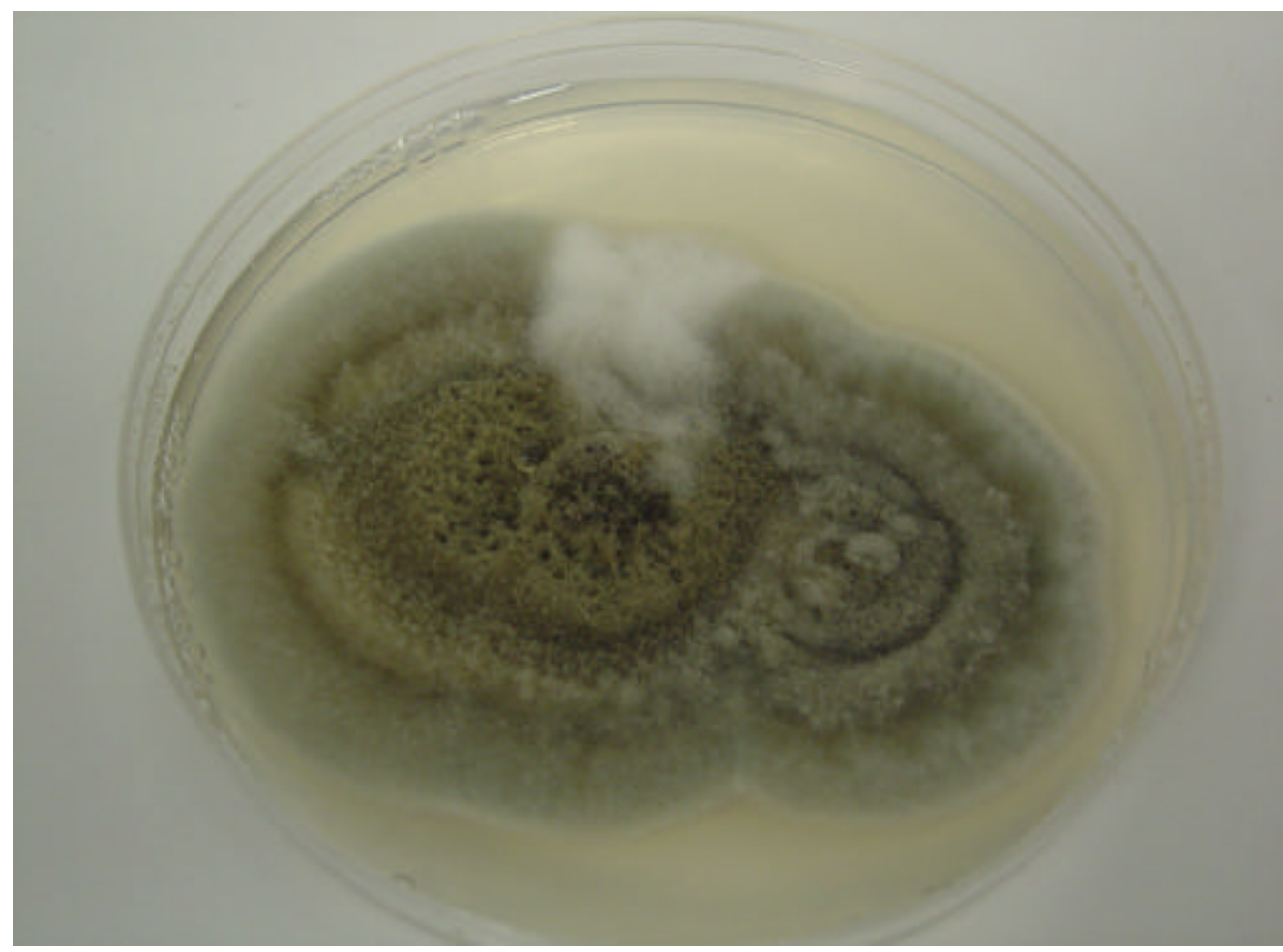


Figure G.9 Unknown 7 on PDA

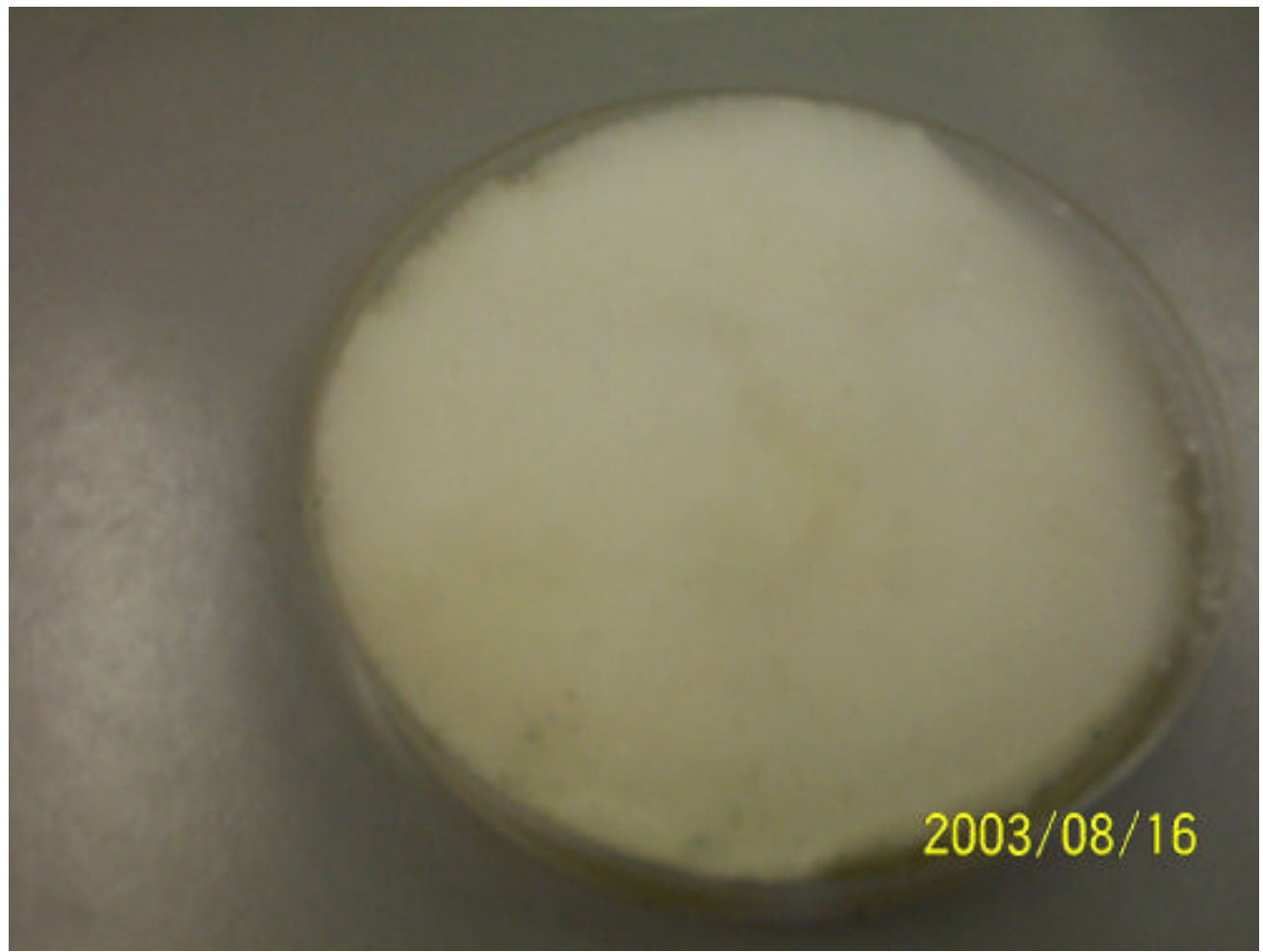

Figure G.10 Unknown 18 on PDA

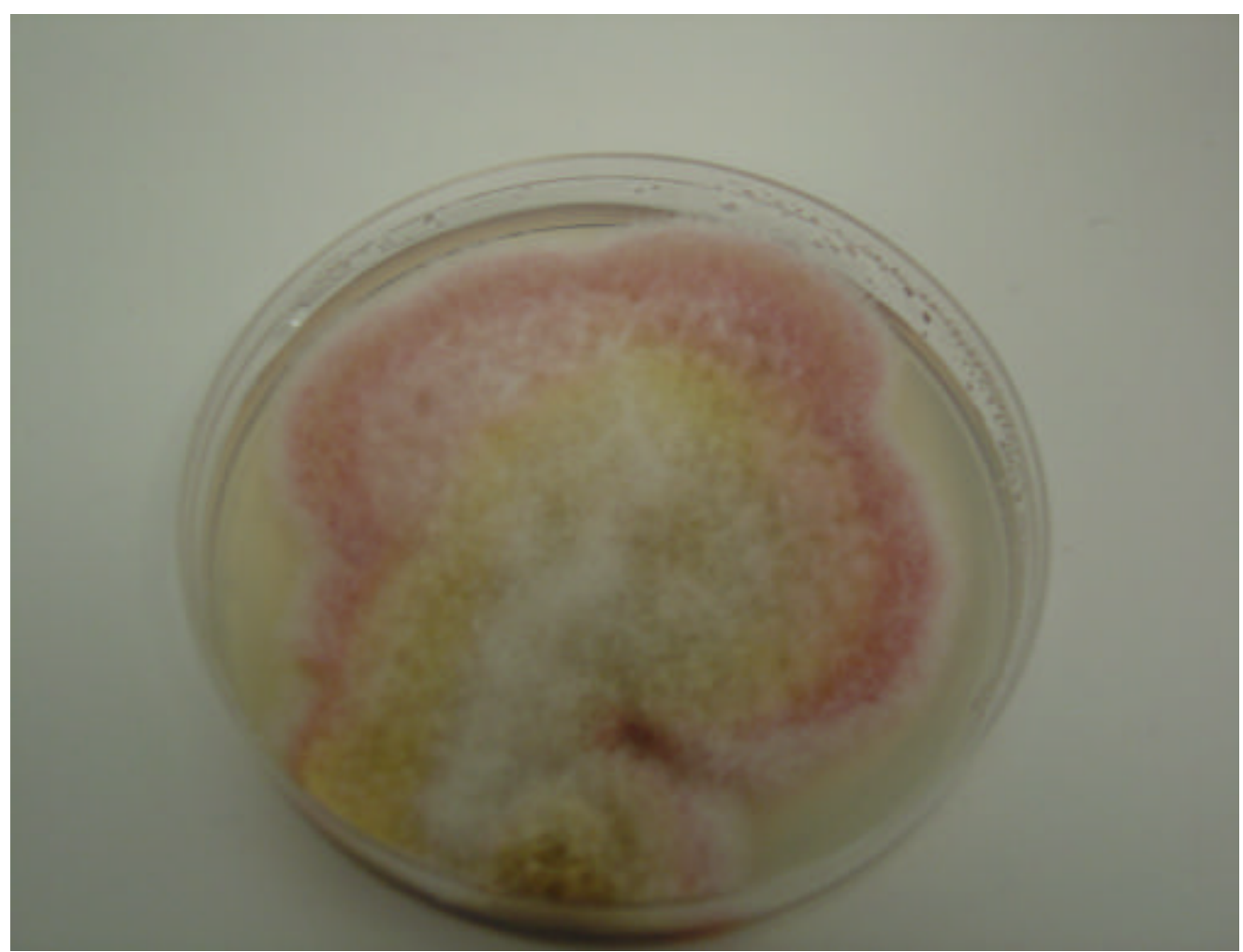


Figure G.11 Unknown 19 on PDA

\section{$2003 / 08 / 16$}

Figure G.12 Unknown 39 on PDA

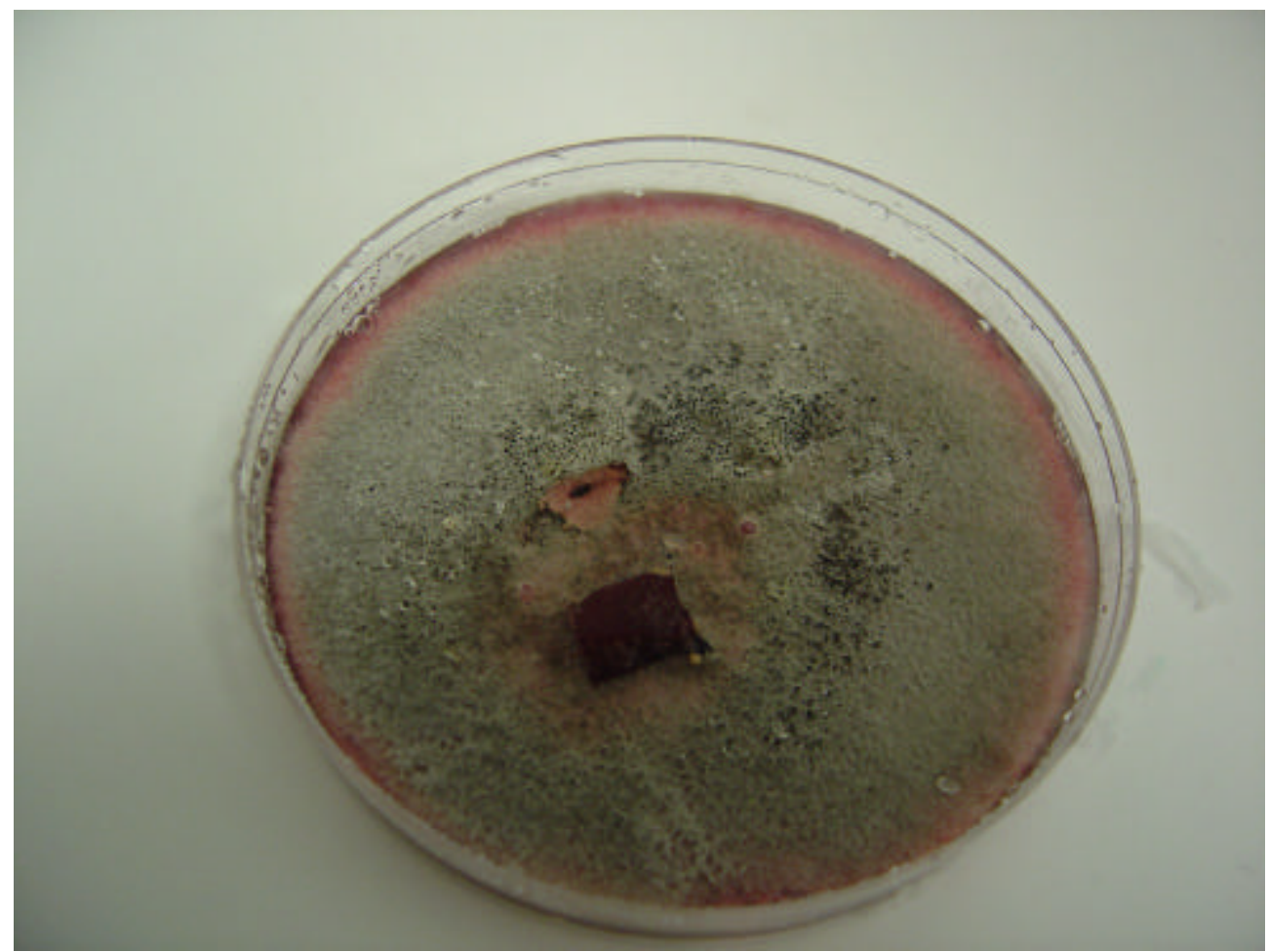

